\title{
AQUIFER SYSTEMS IN THE GREAT BASIN REGION OF NEVADA, UTAH, AND ADJACENT STATES- SUMMARY REPORT
}

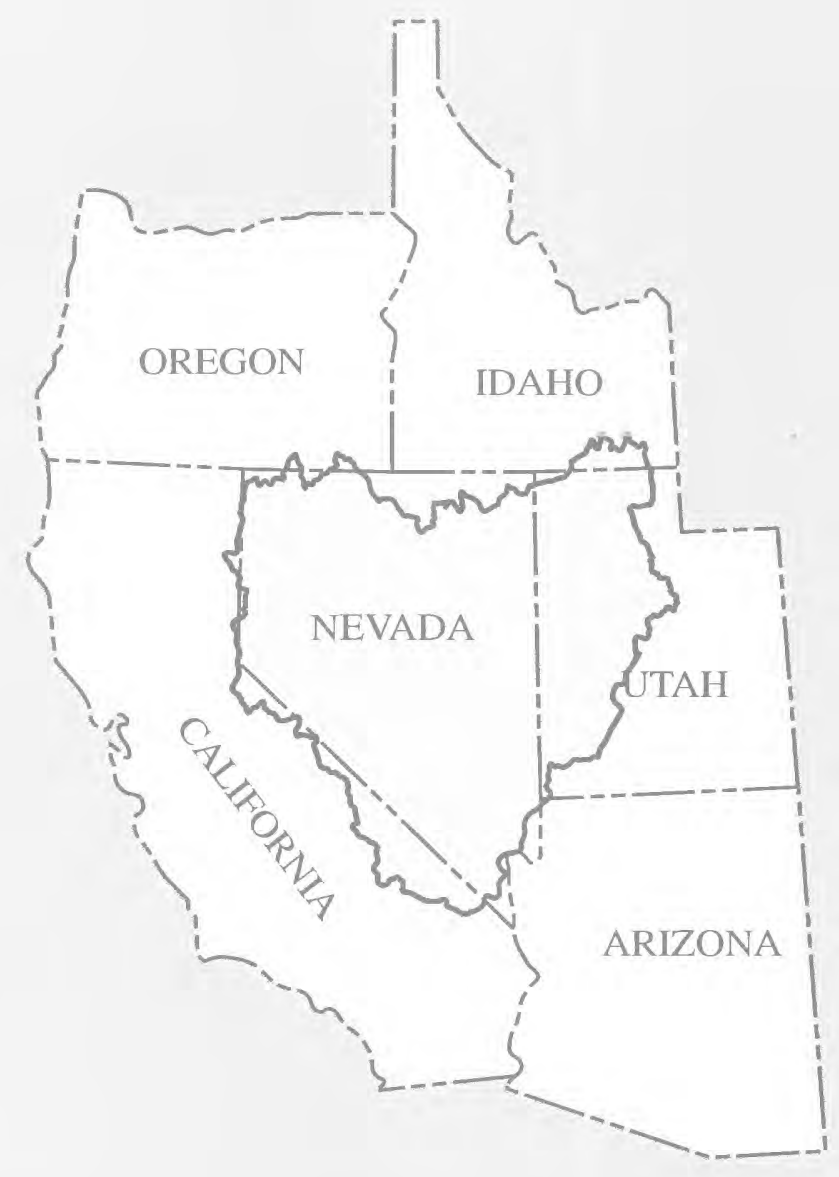




\section{Availability of Publications of the U.S. Geological Survey}

Order U.S. Geological Survey (USGS) publications from the offices listed below. Detailed ordering instructions, along with prices of the last offerings, are given in the current-year issues of the catalog "New Publications of the U.S. Geological Survey."

\section{Books, Maps, and Other Publications}

By Mail

Books, maps, and other publications are available by mail from-

USGS Information Services

Box 25286, Federal Center

Denver, CO 80225

Publications include Professional Papers, Bulletins, WaterSupply Papers, Techniques of Water-Resources Investigations, Circulars, Fact Sheets, publications of general interest, single copies of permanent USGS catalogs, and topographic and thematic maps.

\section{Over the Counter}

Books, maps, and other publications of the U.S. Geological Survey are available over the counter at the following USGS Earth Science Information Centers (ESIC's), all of which are authorized agents of the Superintendent of Documents:

- Anchorage, Alaska-Rm. 101, 4230 University Dr.

- Denver, Colorado-Bldg. 810, Federal Center

- Menlo Park, California-Rm. 3128, Bldg. 3, 345 Middlefield Rd.

- Reston, Virginia-Rm. 1C402, USGS National Center, 12201 Sunrise Valley Dr.

- Salt Lake City, Utah-2222 West, 2300 South (books and maps available for inspection only)

- Spokane, Washington-Rm. 135, U.S. Post Office Building, 904 West Riverside Ave.

- Washington, D.C.-Rm. 2650, Main Interior Bldg., 18th and C Sts., NW.

Maps only may be purchased over the counter at the following USGS office:

- Rolla, Missouri-1400 Independence Rd.

\section{Electronically}

Some USGS publications, including the catalog "New Publications of the U.S. Geological Survey" are also available electronically on the USGS's World Wide Web home page at http://www.usgs.gov

\section{Preliminary Determination of Epicenters}

Subscriptions to the periodical "Preliminary Determination of Epicenters" can be obtained only from the Superintendent of
Documents. Check or money order must be payable to the Superintendent of Documents. Order by mail from-

Superintendent of Documents

Government Printing Office

Washington, DC 20402

\section{Information Periodicals}

Many Information Periodicals products are available through the systems or formats listed below:

\section{Printed Products}

Printed copies of the Minerals Yearbook and the Mineral Commodity Summaries can be ordered from the Superintendent of Documents, Government Printing Office (address above). Printed copies of Metal Industry Indicators and Mineral Industry Surveys can be ordered from the Center for Disease Control and Prevention, National Institute for Occupational Safety and Health, Pittsburgh Research Center, P.O. Box 18070, Pittsburgh, PA 15236-0070.

\section{Mines FaxBack: Return fax service}

1. Use the touch-tone handset attached to your fax machine's telephone jack. (ISDN [digital] telephones cannot be used with fax machines.)

2. Dial (703) 648-4999.

3. Listen to the menu options and punch in the number of your selection, using the touch-tone telephone.

4. After completing your selection, press the start button on your fax machine.

\section{CD-ROM}

A disc containing chapters of the Minerals Yearbook (199395), the Mineral Commodity Summaries (1995-97), a statistical compendium (1970-90), and other publications is updated three times a year and sold by the Superintendent of Documents, Government Printing Office (address above).

\section{World Wide Web}

Minerals information is available electronically at http://minerals.er.usgs.gov/minerals/

\section{Subscription to the catalog "New Publications of the U.S. Geological Survey"}

Those wishing to be placed on a free subscription list for the catalog "New Publications of the U.S. Geological Survey" should write to-

U.S. Geological Survey

903 National Center

Reston, VA 20192 


\section{Aquifer Systems in the Great Basin Region of Nevada, Utah, and Adjacent States- Summary Report}

By JAMES R. HARRILL and DAVID E. PRUDIC

REGIONAL AQUIFER-SYSTEM ANALYSIS—GREAT BASIN, NEVADA-UTAH

U.S. GEOLOGICAL SURVEY PROFESSIONAL PAPER 1409-A

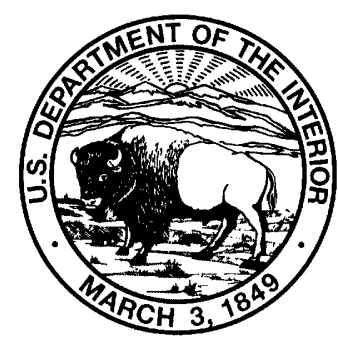

United States GOVERnMENT PRINTING OfFICE, WASHINGTON : 1998 


\title{
U.S. DEPARTMENT OF THE INTERIOR \\ BRUCE BABBITT, Secretary
}

\author{
U.S. GEOLOGICAL SURVEY
}

THOMAS J. CASADEVALL, Acting Director

\begin{abstract}
Any use of trade, product, or firm names in this publication is for descriptive purposes only and does not imply endorsement by the

U.S. Government
\end{abstract}

Library of Congress Cataloging-in-Publication Data

Harrill, James R.

Aquifer systems in the Great Basin region of Nevada, Utah, and adjacent states : summary report / by James R. Harrill and David E. Prudic.

p. cm. - (Regional aquifer-system analysis-Great Basin, Nevada-Utah) (U.S. Geological Survey professional paper ; 1409-A)

Includes bibliographical references.

Supt. of Docs. no. : I 19.16 : 1409-A

1. Aquifers-Great Basin. I. Prudic, David E. II. Title. III. Series. IV. Series : U.S. Geological Survey professional paper ; 1409-A.

GB1199.3.G73H37 1998

551.49'0979-dc21 98-34846

ISBN 0-607-90058-X

For sale by U.S. Geological Survey, Branch of Information Services, Denver Federal Center, Box 25286, Denver, CO 80225-0286 


\section{FOREWORD}

\section{THE REGIONAL AQUIFER-SYSTEM ANALYSIS PROGRAM}

The Regional Aquifer-System Analysis (RASA) program was started in 1978 following a congressional mandate to develop quantitative appraisals of the major ground-water systems of the United States. The RASA program represents a systematic effort to study a number of the Nation's most important aquifer systems, which in aggregate underlie much of the country and which represent an important component of the Nation's total water supply. In general, the boundaries of these studies are identified by the hydrologic extent of each system and accordingly transcend the political subdivisions to which investigations have often arbitrarily been limited in the past. The broad objective for each study is to assemble geologic, hydrologic, and geochemical information, to analyze and develop an understanding of the system, and to develop predictive capabilities that will contribute to the effective management of the system. The use of computer simulation is an important element of the RASA studies, both to develop an understanding of the natural, undisturbed hydrologic system and the changes brought about in it by human activities, and to provide a means of predicting the regional effects of future pumping or other stresses.

The final interpretive results of the RASA program are presented in a series of U.S. Geological Survey Professional Papers that describe the geology, hydrology, and geochemistry of each regional aquifer system. Each study within the RASA program is assigned a single Professional Paper number, and where the volume of interpretive material warrants, separate topical chapters that consider the principal elements of the investigation may be published. The series of RASA interpretive reports begins with Professional Paper 1400 and thereafter will continue in numerical sequence as the interpretive products of subsequent studies become available.

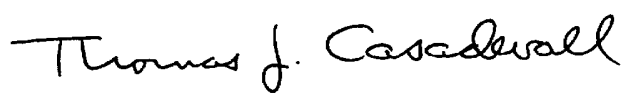

Thomas J. Casadevall Acting Director 


\section{PREFACE}

The Regional Aquifer-System Analysis of the Great Basin was conducted by U.S. Geological Survey personnel in Nevada and Utah. A supporting contract to study recharge processes was awarded to the Desert Research Institute of the University of Nevada. During the initial years of the study, the U.S. Air Force conducted a siting investigation for the proposed MX missile system in parts of Nevada and Utah. The Air Force allowed ready access to this data, which provided much useful information for the RASA program. In addition, valuable information was provided by many State and local agencies throughout the Great Basin. Their contributions are an integral part of this investigation, and without them this report would not have been possible. 


\section{CONTENTS}

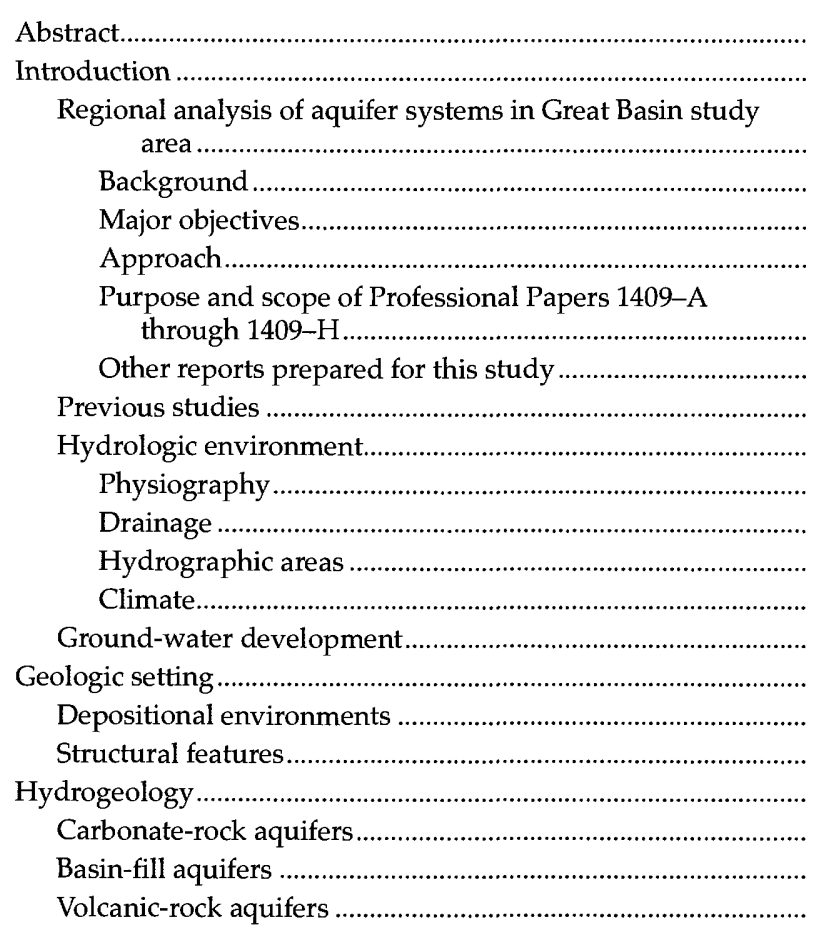

\begin{tabular}{|c|c|c|}
\hline \multicolumn{2}{|l|}{ Page } & Page \\
\hline A1 & Hydrogeology-Continued & \\
\hline 2 & Barriers to regional ground-water flow & A19 \\
\hline & Ground-water recharge & 23 \\
\hline 2 & 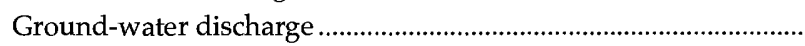 & 25 \\
\hline 2 & 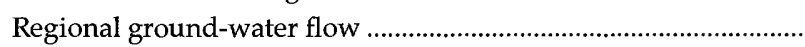 & 27 \\
\hline $\begin{array}{l}4 \\
4\end{array}$ & Concepts of regional flow & 27 \\
\hline 4 & 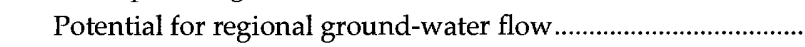 & 28 \\
\hline 4 & 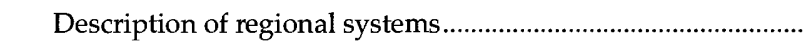 & 28 \\
\hline 5 & 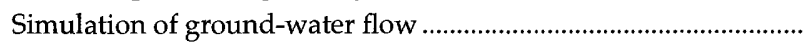 & 35 \\
\hline 5 & Simulation of regional ground-water flow in carbonate-rock & \\
\hline 6 & & 35 \\
\hline 6 & Fish Springs flow system & 42 \\
\hline 6 & Comparison of simulation results from Fish Springs & \\
\hline 7 & model and results from carbonate-rock province & \\
\hline 7 & 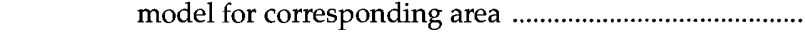 & 42 \\
\hline 7 & 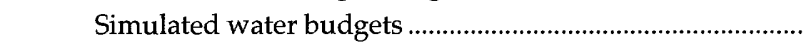 & 42 \\
\hline 7 & Transmissivity distributions & 48 \\
\hline 7 & 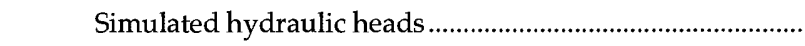 & 48 \\
\hline 9 & Simulation of ground-water flow in basin-fill aquifers................. & 49 \\
\hline 15 & Water quality and geochemistry & 56 \\
\hline 15 & 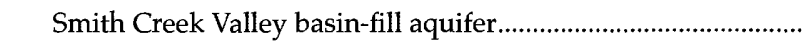 & 56 \\
\hline 17 & 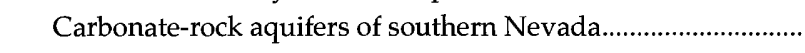 & 58 \\
\hline 19 & References cited & 61 \\
\hline
\end{tabular}

\section{ILLUSTRATIONS}

FIGURES 1-6. Maps showing:

1. Location and general features of study area, Great Basin Regional Aquifer System

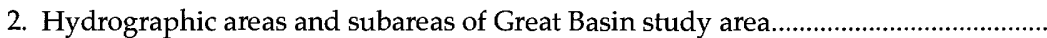

3. Estimated ground-water withdrawals for 1975 in hydrographic areas and subareas of Great Basin study area ..........

4. Occurrence of depositional facies of early Mesozoic and older rocks in Great Basin study area ....................................

5. Selected geologic features of Great Basin study area.

6. Hydrogeologic units of Great Basin study area.

7. Idealized sections showing basin geometry for six representative hydrographic areas in Great Basin study area .....

8-10. Maps showing:

8. Potential barriers to regional ground-water flow in carbonate-rock province.

9. Major source areas for ground-water recharge.

10. Areas where estimates of recharge were used to define relation between recharge and mean annual precipitation in excess of 8 inches

11. Graph showing relation between recharge and mean annual precipitation volume where precipitation rate exceeds 8 inches per year.

12. Map showing locations of large springs and areas of ground-water discharge by evapotranspiration ...................................

13. Schematic diagrams showing ground-water flow from recharge areas in mountains to discharge areas on basin floors. $A$, Generalized hydrogeologic section. B, Finite-difference computer model. C, Water budget within area encompassed by deep-flow region on basis of computer-model output. 
FIGURES 14-20. Maps showing:

14. Regional ground-water flow potential.

15. Major ground-water flow systems ..........

16. Representative basins and regional systems used to model ground-water flow in Great Basin Regional AquiferSystem Analysis

17. High transmissivity in lower model layer in relation to springs used in model simulations and to boundary of central corridor of thick carbonate rocks in south-central Nevada .

18. Deep-flow regions and subregions in carbonate-rock aquifers (lower model layer) based on simulated hydraulic heads.

19. Transmissivity in lower layers of ground-water flow models for Fish Springs and carbonate-rock province..............

20. Simulated water-level contours for Fish Springs ground-water flow system and for comparable area of carbonaterock province, upper and lower model layers.

21. Sketches showing hydrogeologic section and three-dimensional finite-difference model of basin-fill aquifer.

22-24. Maps showing:

22. Dissolved-solids concentration in water from principal aquifers in Great Basin study area ...

23. Location and general hydrologic features of Smith Creek Valley Hydrographic Area.

24. Ground-water flow (rate and direction) in carbonate-rock aquifers of southern Nevada

\section{TABLES}

TABLE 1. Hydrographic areas and flow systems within study area, Great Basin Regional Aquifer System.

2. Aquifers and confining units in Great Basin study area

3. Recharge estimated by Maxey-Eakin and chloride-balance methods for selected areas where annual precipitation exceeds 8 inches in Great Basin study area .....

4. Selected characteristics of major ground-water flow systems in Great Basin study area.

5. Simulated predevelopment ground-water flow budgets for five deep-flow regions of carbonate-rock province.

6. Predevelopment ground-water budgets from Fish Springs ground-water flow model and from carbonate-rock province ground-water flow model for comparable area.

7. Selected characteristics and hydraulic properties of five basin-fill aquifer models used in this study ..........................................

8. Simulated responses to pumping scenario where pumping equals estimated natural recharge and discharge and is distributed strategically to capture discharge.

9. Flow velocities in carbonate-rock aquifers, southern Nevada, calculated from adjusted carbon-14 ages and hydrologic data........

\section{CONVERSION FACTORS, VERTICAL DATUM, AND WATER-QUALITY UNITS}

\begin{tabular}{|c|c|c|}
\hline Multiply & By & To obtain \\
\hline acre & 0.4047 & hectare \\
\hline $\begin{array}{r}\text { acre-foot (acre-ft) } \\
\text { cubic foot per second }\left(\mathrm{ft}^{3} / \mathrm{s}\right)\end{array}$ & $\begin{array}{l}0.001233 \\
0.02832\end{array}$ & $\begin{array}{l}\text { cubic hectometer } \\
\text { cubic meter per second }\end{array}$ \\
\hline foot $(\mathrm{ft})$ & 0.3048 & meter \\
\hline foot per day (ft/d) & 0.3048 & meter per day \\
\hline gallon per minute (gal/min) & 0.06309 & liter per second \\
\hline inch (in.) & 25.4 & millimeter \\
\hline mile (mi) & 1.609 & kilometer \\
\hline square foot $\left(\mathrm{ft}^{2}\right)$ & 0.0929 & square meter \\
\hline square foot per second $\left(\mathrm{ft}^{2} / \mathrm{s}\right)$ & 0.0929 & square meter per second \\
\hline square mile $\left(\mathrm{mi}^{2}\right)$ & 2.59 & square kilometer \\
\hline ton & 907.2 & kilogram \\
\hline
\end{tabular}

Sea level: In this report, "sea level" refers to the National Geodetic vertical Datum of 1929 (NGVD of 1929, formerly called Sea-Level Datum of 1929), which is derived from a general adjustment of the first-order leveling networks of the United States and Canada.

Abbreviated water-quality unit used in this report: $\mathrm{mg} / \mathrm{L}$, milligram per liter 


\title{
AQUIFER SYSTEMS IN THE GREAT BASIN REGION OF NEVADA, UTAH, AND ADJACENT STATES-SUMMARY REPORT
}

\author{
By JAMEs R. HARrill and DAVID E. PRudiC
}

\begin{abstract}
The Great Basin Regional Aquifer-System Analysis (RASA) study area encompasses about 140,000 square miles in parts of Nevada, Utah, California, Oregon, Idaho, and Arizona. It contains numerous basins that collectively constitute a regional ground-water resource. Included are basins that have hydraulic continuity through permeable consolidated rock, basins that are linked by river systems, and basins that function as independent hydrologic systems. A special situation exists in western Utah and eastern Nevada where the basins are underlain and bounded by thick sequences of permeable carbonate rocks.

The study area is characterized by generally parallel, north- to northeast-trending mountain ranges separated by broad alluvial desert basins. The higher ranges in central and eastern Nevada and along the east and west margins of the region have crests more than 10,000 feet above sea level; elsewhere, altitudes of the mountains generally are less than 9,000 feet. Altitudes of valley floors range from below sea level in Death Valley to about 7,000 feet in central Nevada. A total of 260 hydrographic areas or subareas are presently recognized within the Great Basin region. Most of these hydrographic areas contain a basin-fill ground-water reservoir and include the topographically tributary drainage area in the adjacent mountains.

The Great Basin study area is separated into eastern and western areas on the basis of depositional facies of continental-shelf and continental-slope and -rise deposits. The western area includes the approximate western one-third of the Great Basin and is characterized by deepwater marine sedimentary rocks of Paleozoic and early Mesozoic age. The eastern two-thirds of the Great Basin is characterized by alternating sedimentary sequences dominated by clastic rocks, with minor amounts of limestone or dolomite, or by carbonate rocks with minor amounts of clastic rocks. The area dominated by carbonate rocks is known as the carbonate-rock province, a 100,000-square-mile area that lies mostly in eastern Nevada and western Utah. Generally, the overall thickness of carbonate-rock sequences exceeds that of clastic-rock sequences. The combined thicknesses of the carbonate- and clastic-rock sequences that compose the Paleozoic section range from about 5,000 feet to nearly 30,000 feet. The dominant structural features are fault-block mountains and basins of Cenozoic age that formed as a result of extensional faulting.

Aquifer recharge is from precipitation, usually in the form of winter storms in the adjacent mountains. Recharge may occur either in the mountains (from melting snowpack) or along streams flowing over allu-

vial deposits adjacent to the mountains, depending on characteristics of the rock units that form the mountains. The timing and frequency of recharge also varies widely. Estimating natural recharge to the desert basins included in the RASA study area is difficult. The technical approach most commonly applied in Nevada and Utah is an empirical one developed in the 1940's and 1950's. In this study, a chloride-balance method was used to estimate natural ground-water recharge to 16 basins in Nevada, and results compared favorably with existing empirical estimates.

Most ground-water discharge is by evapotranspiration, and most spring discharge ultimately is consumed by evapotranspiration. The principal areas of ground-water discharge are in topographically low parts of valleys where the water table is near the land surface. Estimates of ground-water evapotranspiration are not available for every basin in the study area. However, if the system is considered to be in a general state of dynamic equilibrium, then the total natural ground-water discharge is about equal to the recharge, which is about 3.8 million acre-feet per year for the entire study area.

Thirty-nine major flow systems were delineated. They range from 30 to 18,000 square miles in area. Sixteen are single-basin systems, and the remainder are multibasin systems that may include as many as 34 hydrographic areas or subareas. Except in the carbonate-rock province, large multibasin flow systems are generally coincident with major river systems. Large multibasin systems within the carbonate-rock province typically have little surface flow but may contain ground-water flow paths more than 100 miles long that traverse several basins. Discharge from these systems is typically from large springs. This discharge generally is consumed by evapotranspiration in the vicinity of the spring. An exception is the Muddy River springs that discharge into the Muddy River, which is a tributary of the Colorado River.

A three-dimensional finite-difference ground-water flow model was used to evaluate regional ground-water flow in the carbonate-rock province. The model simulated 45 shallow-flow regions in the upper model layer and 17 deep-flow subregions in the lower layer. The deep-flow subregions were further grouped into five deep-flow regions on the basis of areas having simulated water levels that generally decline toward one of five regional discharge areas. These are called the Death Valley, Colorado River, Bonneville, Railroad Valley, and upper Humboldt River regions.
\end{abstract}


Analysis of the model simulations has led to several conclusions: (1) Most ground-water flow is relatively shallow, moving from recharge areas in the mountains to discharge areas in adjacent valleys. (2) lnterbasin movement of ground water to the larger regional springs is through thick, hydraulically continuous, permeable carbonate rock. (3) ln some areas, consolidated rocks beneath the valleys and surrounding mountains are not highly transmissive; either not all carbonate rock is highly permeable or not all valleys and surrounding mountains are underlain by carbonate rock. (4) In some areas, carbonate rocks may be highly transmissive but separated from overlying aquifers by low-permeability rocks or deposits. (5) Deep flow discharges at the major downgradient terminal sinks only in relatively small quantities. Instead, deep flow discharges mainly to regional springs and areas of evapotranspiration upgradient from the sinks. (6) Simulated deep flow in the upper Humboldt River region is low in volume because most of the ground water discharging along the river is from local flow associated with the river.

Five basin-fill aquifers were selected as representative examples of the large range of conditions across in the study area. They are the Milford area in Utah and the Carson, Paradise, Smith Creek, and Stagecoach Valleys in Nevada. The Milford area represents a large basin-fill aquifer under sustained development; Carson Valley represents a basin-fill aquifer dominated by a through-flowing river; Paradise Valley represents a basin-fill reservoir having an upgradient part dominated by streams and an arid lower part; Smith Creek Valley represents a topographically closed, arid basin; and Stagecoach Valley represents a small, topographically closed basin that is partly drained by subsurface flow.

Results indicate that if pumping is located strategically with respect to areas of natural discharge, then a sustained-yield concept may be a viable management option. If pumping is not located strategically with respect to discharge or is highly concentrated, the sustained-yield concept may not be viable because localized drawdowns can become large before all natural discharge is captured. The location of pumping and the degree to which pumping is concentrated can be as significant as the overall pumping rate in determining response to pumping. Where streams and rivers are in hydraulic continuity with ground water, the location of pumping relative to these features is important in determining response to pumping.

Water in the principal aquifers of the Great Basin generally contains less than 1,000 milligrams of dissolved solids per liter, except in naturaldischarge and geothermal areas. Geochemical and hydrologic processes responsible for the major-ion chemistry and isotopic composition of water in aquifers throughout the Great Basin have been identified for representative examples of the two principal types of flow systems, a hydrologically closed basin-fill aquifer in west-central Nevada and a regional carbonate-rock aquifer in southern Nevada.

The main processes controlling geochemical evolution of ground water in the closed basin-fill aquifer of Smith Creek Valley are (1) dissolution of volcanic tuff and tuff-derived basin-fill deposits, (2) cation exchange of calcium and magnesium in the water for sodium in clay minerals, (3) weathering of plagioclase to montmorillonite, (4) precipitation of zeolite minerals, (5) concentration of dissolved constituents by evapotranspiration, (6) dissolution of chloride and sulfate evaporative salts, and (7) precipitation of calcite.

Major-ion chemical and isotopic compositions of water in the carbonate-rock aquifers of southern Nevada evolve because of (1) dissolution of minerals and soil-zone carbon dioxide gas, (2) precipitation or formation of minerals, (3) ion exchange, (4) mixing of chemically or isotopically different waters, and (5) geothermal heating. For instance, gypsum dissolves, and the dissolution of gypsum causes dolomite to dissolve and calcite to precipitate; calcium and magnesium are exchanged for sodium in clays; chalcedony precipitates; kaolinite forms; and, in the vicinity of some springs, carbon dioxide gas exsolves. Sodium and potassium probably are added by dissolution of zeolite minerals and of volcanic glass and minerals. Locally, calcium, sodium, sulfate, and chloride are added by dissolution of gypsum and halite.

\section{INTRODUCTION}

The study area for the Great Basin Regional AquiferSystem Analysis (RASA) encompasses about $140,000 \mathrm{mi}^{2}$ and includes most of Nevada and parts of Utah, California, Oregon, Idaho, and Arizona (fig. 1). This area contains numerous basins that collectively constitute a significant regional ground-water resource. Most of the basins share many common geologic and hydrologic characteristics that facilitate their study as a group. In addition to basins that function as independent hydrologic systems, this group includes contiguous basins that have hydraulic continuity through permeable masses of consolidated rock or that are linked by river systems. In parts of western Utah and eastern Nevada, structural basins are underlain and bounded by thick sequences of permeable carbonate rocks; this special situation results in complex flow systems that contain both basin-fill and carbonate-rock aquifers.

The Great Basin RASA study focuses on two important aquifer systems, one composed of basin-fill aquifers and the other of carbonate-rock aquifers. Most of the basins throughout the study area contain basin-fill aquifers, most of which physically (but not necessarily hydraulically) are separated by intervening mountain ranges composed of consolidated rock. The carbonate-rock aquifers are within the carbonate-rock province, a $100,000-\mathrm{mi}^{2}$ area that is mostly in eastern Nevada and western Utah. This area is characterized by some degree of hydraulic continuity between basins through the carbonate-rock aquifers. Several large multibasin ground-water flow systems have been identified in the carbonate-rock province.

\section{REGIONAL ANALYSIS OF AQUIFER SYSTEMS IN GREAT BASIN STUDY AREA}

\section{BACKGROUND}

The Great Basin RASA study began in 1981 and most study components were completed in 1987. The Great Basin regional aquifer system was the 10th to be studied as part of the U.S. Geological Survey's (USGS) national RASA program. The Great Basin RASA study area was selected because it encompasses about 260 individual basins that collectively constitute a major regional water resource. The included basins represent a wide variety of hydrologic conditions, ranging from basins that function as isolated flow systems to basins that are hydraulically continuous with adjacent areas and form complex regional flow systems. Surface-water supplies are almost fully appropriated throughout the area, and future development will be supplied either by pumping ground water or by reallocating surface supplies. 


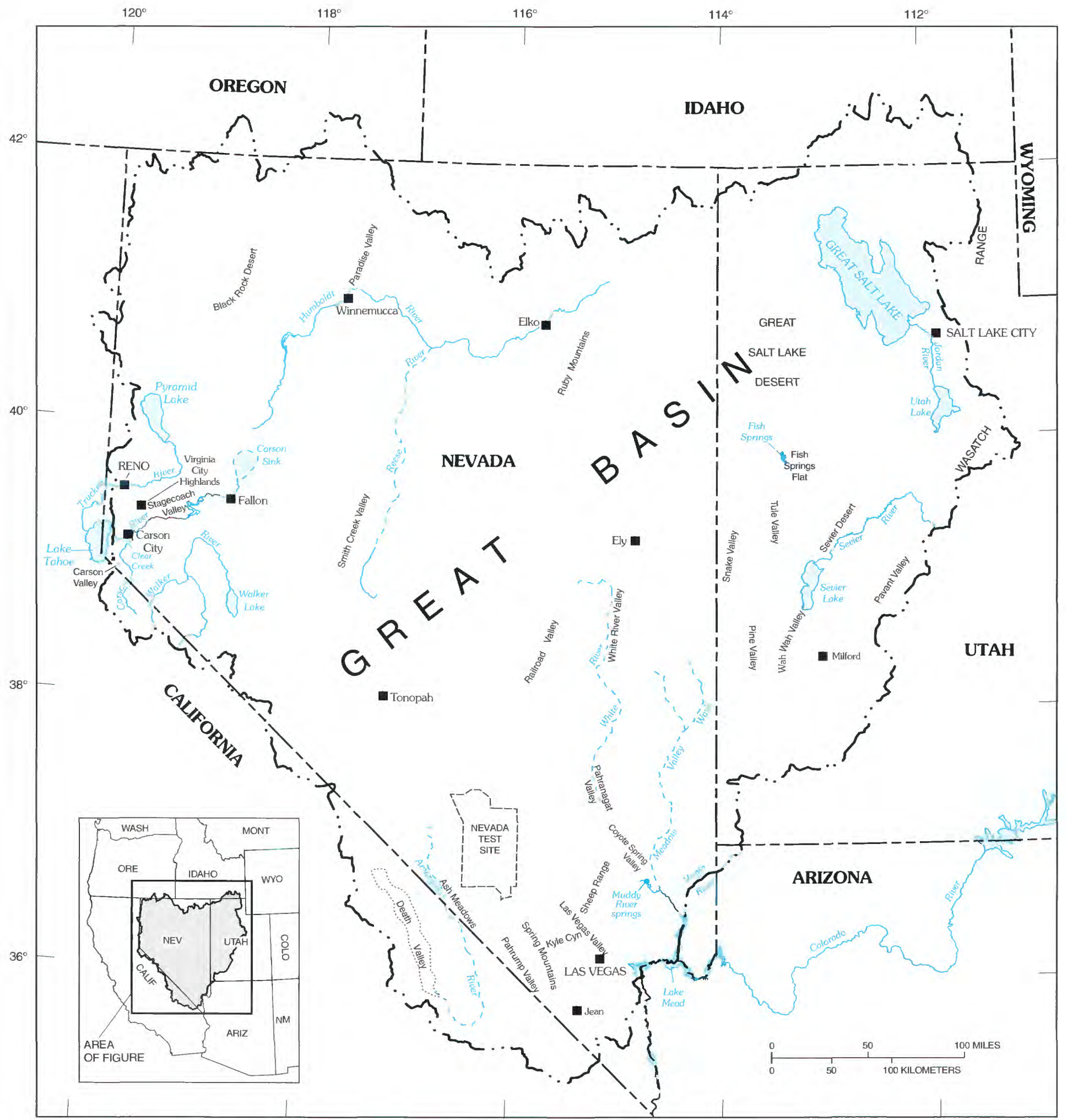

Base from U.S. Geological Survey digital data, 1:100,000, 1978-88, and 1:250,000, 1987 Albers Equal-Area Conic projection

Standard parallels $29^{\circ} 30^{\prime}$ and $45^{\circ} 30^{\prime}$, central meridian $-114^{\circ} 00^{\prime}$

\section{EXPLANATION}




\section{MAJOR OBJECTIVES}

The main purpose of this study was to develop a regional base of information that would support effective future management of ground water in this area. This regional information includes a description of the present and predevelopment conditions of the ground-water flow system and an analysis of the changes that have led to the present conditions. Specific objectives were to improve understanding of the flow system (including sources and rates of recharge and discharge), of the hydraulic properties of aquifers and confining units, of the functioning of multibasin flow systems, and of the effects of man's past and present activities on the aquifer systems of the Great Basin.

\section{APPROACH}

The approach taken to meet the objectives of this study was strongly influenced by the diverse nature of groundwater flow systems and the large number of basins in the study area. Not all hydrologic characteristics can be described regionally; however, a detailed appraisal of 260 individual hydrographic areas or subareas was not feasible. Consequently, the general approach was to identify the key components and critical properties of groundwater flow systems throughout the study area. These were studied in selected "type areas" that have conditions representative of the region. Information developed during these area evaluations has transfer value, and the final phase of this project involved developing a regional analysis that included the extrapolation of as much information as possible to the entire study area.

\section{PURPOSE AND SCOPE OF PROFESSIONAL PAPERS 1409-A THROUGH 1409-H}

The Professional Paper 1409 series consists of eight reports that describe various aspects of the geology, hydrology, and geochemistry of aquifer systems in the Great Basin RASA study area. The main focus of these reports is the description of regional and local groundwater flow systems. Particular emphasis is placed on geologic factors that control regional ground-water flow and on the manner in which various types of systems respond to sustained pumping stresses over the long term.

In Professional Paper 1409-A (this report), we summarize the hydrogeologic framework, hydraulic properties of the aquifers, regional flow systems, effects of groundwater development, and geochemistry of the Great Basin study area. These topics are discussed in detail in Professional Papers 1409-B through 1409-H and in several of the additional reports prepared in support of this study (see section "Other Reports Prepared For This Study"). This report includes considerable material incorporated directly (and, in places, verbatim) from many of the nearly 60 reports that are products of the Great Basin Regional Aquifer System Analysis (see "References Cited").

In Professional Paper 1409-B, Plume (1996) described the hydrogeologic framework of the Great Basin study area. The discussion includes geologic features that control ground-water flow within individual basins and geologic features that control regional ground-water flow.

In Professional Paper 1409-C, Thomas and others (1996) described the aqueous geochemistry of aquifer systems in the Great Basin study area.

In Professional Paper 1409-D, Prudic and others (1995) described the simulation of regional ground-water flow in parts of western Utah, eastern Nevada, and southwestern California that are underlain by permeable carbonaterock aquifers.

In Professional Paper 1409-E, Thomas, Carlton, and Hines (1989) described the hydrology of Smith Creek Valley, a hydrologically closed basin in Lander County (central Nevada). A ground-water flow model was used to simulate conditions prior to significant development and then to evaluate the response to selected developmental alternatives.

In Professional Paper 1409-F, Prudic and Herman (1996) described the hydrology of Paradise Valley in northwestern Nevada. Paradise Valley is a tributary area of the Humboldt River. The hydrologic regimen of the upper part of the basin is dominated by streamflow whereas the lower part of the basin is arid. A groundwater flow model was used to simulate conditions prior to significant development and then to evaluate responses to selected developmental scenarios.

In Professional Paper 1409-G, Mason (1998) described the hydrology of the Milford area, a large, heavily pumped basin in central Utah. A ground-water flow model was used to simulate conditions prior to significant pumping and then to evaluate responses to selected developmental scenarios.

In Professional Paper 1409-H, Harrill and Preissler (1994) described the hydrology of Stagecoach Valley, a small topographically closed basin in western Nevada that is partly drained by subsurface flow. A ground-water flow model was used to simulate conditions prior to significant pumping and then to evaluate responses to selected developmental scenarios. 


\section{OTHER REPORTS PREPARED FOR THIS STUDY}

During the Great Basin RASA study, companion reports were prepared on hydrologic data by Bunch and Harrill (1984) and Mason and others (1985); on hydrogeology by Gates (1984), Harrill and others (1984, 1992), Plume and Carlton (1988), and Harrill and Hines (1995); on water quality by Welch and Thomas (1984), Thomas, Welch, and Preissler (1985, 1989), Welch and Williams (1986a-d, 1987a-j), and Thomas, Carlton, and Hines (1989); on evapotranspiration by Carman $(1985,1989$, 1993) and Hines (1992); on recharge by Campana and Boone (1986), Schulke (1987), and Dettinger (1989b); on hydrologic applications of geophysics by Plume (1984; $1985 ; 1988 a, b)$, Schaefer and others $(1984,1986)$, Robbins and others (1985), and Schaefer (1988); on regional hydrology by Mifflin and Harrill (1981), Harrill (1984), Thomas and others (1986), and Harrill and others (1988); and on ground-water flow modeling by Burbey and Prudic (1985), Carlton (1985), Carlton and Thomas (1987), Schaefer (1993), Carey (1994), Prudic and others (1995), Prudic and Wood (1995), and Carey and Prudic (1996). The course of the study followed the general outline presented in a preliminary planning document by Harrill and others (1983).

\section{PREVIOUS STUDIES}

Numerous studies have been made of various aspects of the hydrology and geology of the Great Basin. Most of these studies pertain to localized areas or specific topics and are too numerous to mention here. This discussion will refer primarily to those studies that include a regional-scale analysis or summary that provides information useful to an analysis of the hydrogeology of the whole region.

One of the first reasonably comprehensive discussions of the area's geology was by Nolan (1943). He summarized and in part interpreted the published information that was available through 1938 on the geology of those parts of Nevada, California, and Utah that were included in the Basin and Range Province. At that time much of the area had not been mapped in detail and much of the subsequent work during the 1950's and 1960's involved quadrangle mapping. By the early 1960's the areal mapping had progressed to the point that regional-scale compilations of the geology were possible. Stokes (1963) and Hintze (1963) compiled 1:250,000-scale maps of northwestern and southwestern Utah, respectively. Jennings (1977) compiled a geologic map of the State of California at a scale of 1:750,000, and Stewart and Carlson (1978) compiled a geologic map of Nevada at a scale of 1:500,000. Hintze (1980) updated the Utah maps and compiled a geologic map of the State of Utah at a scale of 1:500,000.
These compilations contributed greatly to the analysis of the regional stratigraphy and structures. Langenheim and Larson (1973) compiled a correlation of Great Basin stratigraphic units, and when Stewart (1980) described the geology of Nevada, he included detailed summaries of the depositional and structural evolution of the Great Basin. Allmendinger and others $(1983,1987)$ produced deep seismic profiles across the Great Basin, and Wernicke (1985) emphasized the importance of listric and low-angle extensional faulting in the overall tectonic development of the Basin and Range Province.

Much geophysical work has been done in the Great Basin, and since the early 1970's much effort has been put into systematically compiling the information. Both the California Division of Mines and Geology and the Nevada Bureau of Mines and Geology have programs to compile Bouguer gravity data on USGS 1:250,000-scale topographic quadrangles that cover the entire State. Cook and others (1975) compiled a simple Bouguer gravity anomaly map of Utah at a scale of 1:1,000,000. Peterson (1974) provided more-detailed coverage of parts of northwestern Utah. Aeromagnetic information also has been compiled on a regional scale. Hildenbrand and others (1983) compiled the available data to produce a digital colored magnetic-anomaly map of the Basin and Range Province. Much of the seismic data for the area has been compiled by private companies, but much of the information has been made available in the public domain by the Consortium for Continental Reflection Profiling, which surveyed a deep reflection profile across the Great Basin (Allmendinger and others, 1987).

Early investigators working in southern Nevada noted that large springs issued from areas with limited surficial drainage and postulated that subsurface interbasin flow was occurring. Mendenhall (1909, p. 13) suggested that many of the desert springs in southern Nevada were not dependent on rainfall in the region surrounding the springs but that the origin of the water was from distant mountains. Carpenter (1915, p. 19) noted that consolidated rock exposed in the mountains of southeastern Nevada generally makes the adjacent valleys closed to downward leakage by making the sides and bottoms of the valleys practically impervious. He did, however, state that several closed valleys higher in altitude than adjacent valleys lost water through fissures in the rocks because water levels in the higher valleys were far below land surface. Meinzer (1917, p. 150) reported that water from a valley near Tonopah, Nev., leaked through a mountain range into an adjacent valley. These are some of the earliest reports that discuss the possibility of interbasin flow of ground water in the study area. 
The first serious efforts to evaluate regional groundwater flow were in the late 1950's when the USGS began intensive studies on the Nevada Test Site and adjacent lands. These studies have continued to the present time and have developed much information pertaining to regional flow in southern Nevada. The general findings were summarized by Winograd (1962), Winograd and Eakin (1965), Blankennagel and Weir (1973), and Winograd and Thordarson (1975). The next major step to understanding the hydrology of the area on a regional scale was the initiation of a USGS program of reconnaissance-level studies using similar techniques designed to provide areal coverage of Nevada and most of western Utah. The program was initiated in Nevada and subsequently implemented in Utah. It resulted in the publication of 60 reconnaissance reports by the Nevada Department of Conservation and Natural Resources (including Eakin, 1960; 1961a, b; 1962a, b, c; 1963a, b, c; 1964; Malmberg and Eakin, 1962; Sinclair, 1962a, b; 1963a, b, c, d; Cohen and Everett, 1963; Crosthwaite, 1963; Rush and Eakin, 1963; Walker and Eakin, 1963; Cohen, 1964; Eakin and others, 1964, 1967; Everett, 1964; Everett and Rush, 1964, 1965, 1966, 1967; Rush, 1964; 1967; 1968b, c, d; 1971; Rush and Kazmi, 1965; Huxel and others, 1966; Malmberg and Worts, 1966; Rush and Everett, 1966; Rush and Huxel, 1966; Worts and Malmberg, 1966; Rush and Glancy, 1967; Glancy, 1968a, b; 1971; Glancy and Rush, 1968; Harrill, 1968, 1969, 1970, 1971; Glancy and Van Denburgh, 1969; Huxel and Harris, 1969; Van Denburgh and Glancy, 1970; Rush and Katzer, 1973; Van Denburgh and others, 1973; Van Denburgh and Rush, 1974; and Glancy and Katzer, 1976) and 19 reconnaissance reports by the Utah Department of Natural Resources (including Bolke and Price, 1969, 1972; Hood and Waddell, 1969; Hood and others, 1969; Hood, 1971a, b; Stephens and Hood, 1973; Stephens, 1974a, b; 1977; Price and Bolke, 1976; Bolke and Sumsion, 1978; Stephens and Sumsion, 1978; and Gates and Kruer, 1981). The information developed by these studies provided much of the material used in analyzing the hydrology on a regional scale.

Eakin (1966) described the White River flow system, a regional interbasin ground-water system. Mifflin (1968) evaluated flow systems throughout Nevada. He identified 136 systems and separated them into two groups on the basis of the presence or absence of interbasin flow. Mifflin's work was augmented by Scott and others (1971), who prepared a map summarizing information on interbasin flow for 252 areas in Nevada. Winograd and Friedman (1972) demonstrated that ratios of the chemical isotopes deuterium and hydrogen were useful tools for tracing regional ground-water flow in the Great Basin.
Gates and Kruer (1981) described areas thought to be associated with regional ground-water flow in western Utah. Bedinger, Gates, and Stark (1984) and Bedinger, Harrill, and Thomas (1984) presented maps showing ground-water units of the parts of Nevada and Utah that are in the Great Basin; they approximately defined the units on the basis of water-table divides or topographic divides.

\section{HYDROLOGIC ENVIRONMENT}

\section{PHYSIOGRAPHY}

The Great Basin RASA study area is characterized by generally parallel, north- to northeast-trending mountain ranges separated by broad alluvial desert basins. Mountain ranges commonly are 40 to $80 \mathrm{mi}$ long and typically are spaced 5 to $15 \mathrm{mi}$ apart. Their crests commonly are 1,000 to $5,000 \mathrm{ft}$ above the adjacent valley floors. The higher ranges, which are in central and eastern Nevada and along the east and west margins of the study area, have crests more than $10,000 \mathrm{ft}$ above sea level; elsewhere, altitudes of the mountains generally are less than 9,000 ft.

Altitudes of the valley floors range from below sea level in Death Valley to about 7,000 ft in central Nevada; however, the altitudes of the floors of most valleys are 4,000 to $6,000 \mathrm{ft}$. Typically, an intermediate slope separates the valley floor from the bordering mountain ranges. This slope, sometimes called the alluvial apron, is formed either by coalescing alluvial fans or by sedimentary materials thinly mantling eroded bedrock surfaces. Gradients of these slopes generally range from a few tens of feet to several hundreds of feet per mile.

\section{DRAINAGE}

The Basin and Range physiographic province (Fenneman and Johnson, 1946) is an area of about $200,000 \mathrm{mi}^{2}$ of mostly internal drainages; it has few surface outlets to the ocean. The Great Basin is a section in the northern Basin and Range. The Great Basin study area as described in this report includes about $140,000 \mathrm{mi}^{2}$, largely in Nevada and Utah but with smaller components in California, Oregon, Idaho, and Arizona. The study area generally conforms to the Great Basin region as defined by Stewart (1980, p. 7); however, it includes an area of southeastern Nevada that is tributary to the Colorado River and excludes some parts of the Great Basin that are in southeastern California and southern Oregon and the headwater areas of some of the principal drainages in the Sierra Nevada and the Wasatch Range. The principal rivers in the study area are shown in figure 1. 


\section{HYDROGRAPHIC AREAS}

A total of 260 hydrographic areas ${ }^{1}$ or subareas are recognized within the Great Basin region (fig. 2, table 1). These areas usually are the basic units used by State and local agencies for water-resources planning and management, and they commonly include only one topographic basin. Most areas contain a basin-fill ground-water reservoir and include the drainage area in the adjacent mountains. Generally, the topographic and geologic features that constitute the geographic boundaries of the hydrographic areas and subareas correspond to hydrologic boundaries; consequently, boundaries of larger groundwater flow systems generally correspond to boundaries of either hydrographic areas or subareas.

\section{CLIMATE}

Although generally arid to semiarid, the climate of the study area is highly variable, owing to large variations in altitude, the wide range in latitude, and the presence of numerous mountain ranges. Mean annual precipitation in the valleys ranges from less than $5 \mathrm{in}$. to about $16 \mathrm{in}$. and in the mountains from about $16 \mathrm{in}$. to more than $60 \mathrm{in}$. Estimated annual precipitation over the entire region averages about 11 in. (Eakin and others, 1976, p. G3). Most of the precipitation occurs during the winter; mountain snowpack that melts and runs off in the spring and summer is a major component of the region's total water supply.

Mean annual temperature ranges from about $30^{\circ} \mathrm{F}$ in some high northern valleys to about $60^{\circ} \mathrm{F}$ in the extreme southern valleys. One of the more characteristic features is the wide range between daily maximum and minimum temperatures. The daily range exceeds $30^{\circ} \mathrm{F}$ in most valleys and exceeds $50^{\circ} \mathrm{F}$ in some valleys of western Nevada. Large variations in temperature also occur within short distances because of variations in altitude. The average length of the growing season in the principal agricultural areas of the region ranges from about 100 to 175 days; it exceeds 200 days in the extreme south but is less than 30 days in some higher, northern mountain valleys.

Mean annual humidity ranges from about 30 to 40 percent over most of the region and is about 20 percent in the extreme south. During summer months daytime humidity values of less than 10 percent are common in many of the arid valleys. The low humidity, abundant sunshine, and light to moderate winds cause rapid evaporation.

\footnotetext{
${ }^{1}$ Formal hydrographic areas in Nevada were delineated systematically by the U.S. Geological Survey and Nevada Division of Water Resources in the late 1960's (Rush, 1968a; Cardinalli and others, 1968) for scientific and administrative purposes. The official hydrographic-area names, numbers, and geographic boundaries continue to be used in Geological Survey scientific reports and Division of Water Resources administrative activities.
}

Mean annual lake evaporation ranges from about 45 in. in the north to more than $90 \mathrm{in}$. in the extreme south (Kohler and others, 1959).

\section{GROUND-WATER DEVELOPMENT}

Most ground-water withdrawals in the Great Basin RASA study area are from wells drilled into the basin-fill deposits beneath the valley floors because most of the people settled in the valleys, ground water in many of the valleys is generally shallow, and the basin-fill deposits generally yield large quantities of water to wells. Ground water in the valleys is within a few feet to several tens of feet below land surface; water levels are generally deeper in mountain areas. Eakin and others $(1976$, p. 15) reported yields of as much as $8,600 \mathrm{gal} / \mathrm{min}$ from large-capacity wells in north-central Utah.

Prior to World War II, most of the ground-water withdrawals were from flowing wells drilled into basin-fill deposits. Areas of flowing wells were concentrated largely along the east side of the study area in valleys adjacent to the Wasatch Range, although several other valleys, including Las Vegas Valley, had flowing wells. Ground-water withdrawals were generally small and constant until after World War II, when more-efficient pumps and inexpensive energy greatly increased the amount of ground water withdrawn to irrigate crops and supply a rapidly increasing population. The total amount of ground water withdrawn in the study area during 1975 was approximately 1.3 million acre-ft. Major areas of ground-water withdrawals during 1975 are shown in figure 3.

\section{GEOLOGIC SETTING}

\section{DEPOSITIONAL ENVIRONMENTS}

The Great Basin is separated into eastern and western areas (fig. 4) on the basis of the occurrence of depositional facies of continental-shelf and continental-slope and -rise deposits. The western area includes the approximate western one-third of the Great Basin and is characterized by marine sedimentary rocks (chert, shale, siltstone, sandstone, and subordinate limestone) and marine volcanic rocks of Paleozoic and early Mesozoic age. The eastern two-thirds of the Great Basin is characterized by alternating sedimentary sequences that are dominated either by clastic rocks (mostly sandstone, shale, and conglomerate) with minor amounts of carbonate rocks (limestone or dolomite) or by carbonate rocks (limestone and dolomite) with minor amounts of clastic rocks. In general in the eastern Great Basin, the overall thickness of carbonate rocks 


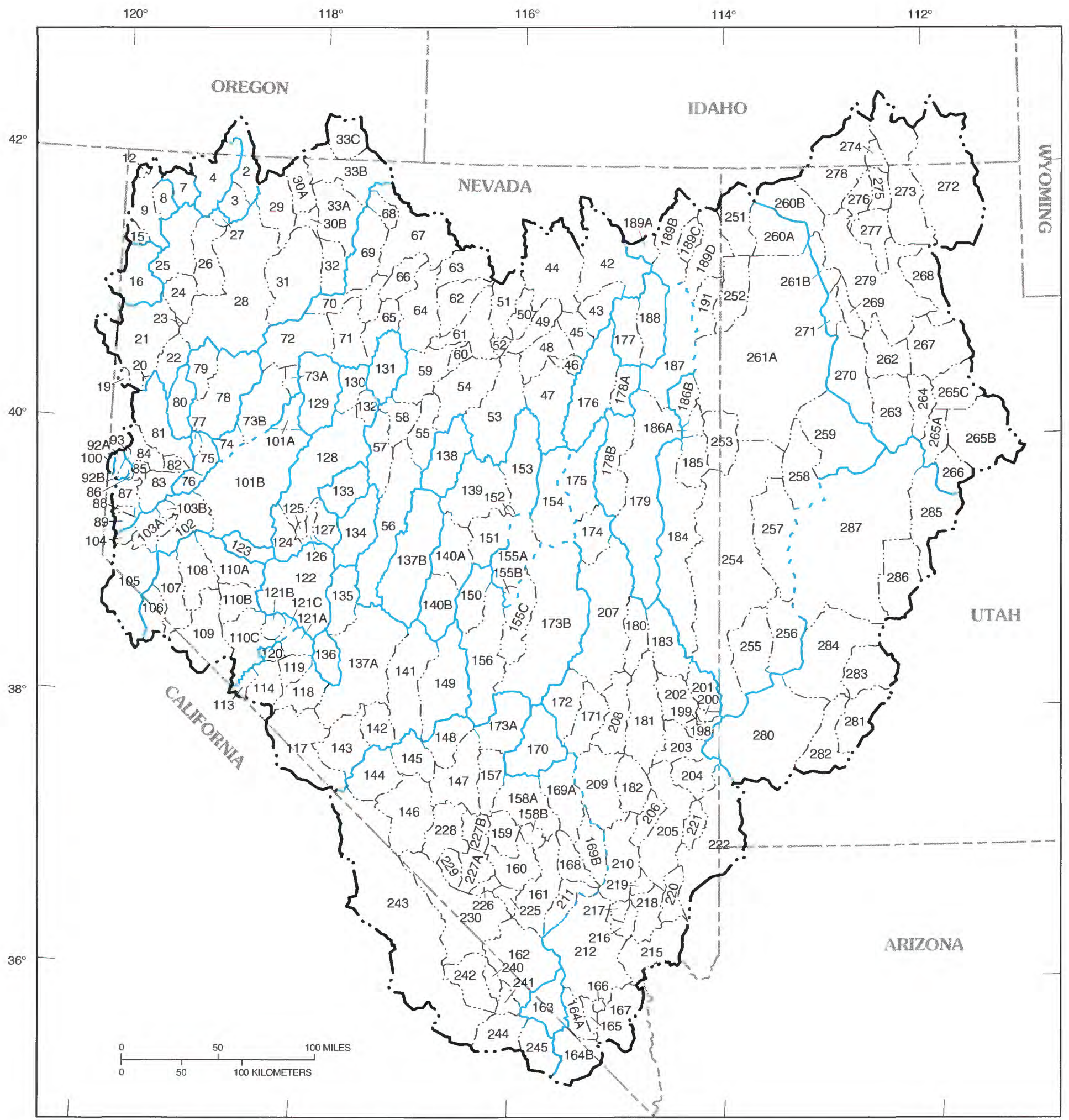

Base from U.S. Geological Survey digital data, 1:100,000, 1978-88, and 1:250,000, 1987 Albers Equal-Area Conic projection

Standard parallels $29^{\circ} 30^{\prime}$ and $45^{\circ} 30^{\prime}$, central meridian $-114^{\circ} 00^{\prime}$

FIGURE 2.-Hydrographic areas and subareas of Great Basin study area as listed in table 1. Also shown are major ground-water flow systems (tables 1 and 4; fig. 15). Modified from Cardinalli and others (1968), Rush (1968a), and Harrill (1988). 
exceeds that of clastic rocks, especially in the Middle Cambrian to Lower Triassic parts of the stratigraphic section. Combined thickness of carbonate and clastic rocks ranges from about $5,000 \mathrm{ft}$ to nearly $30,000 \mathrm{ft}$. The area of eastern and transitional depositional facies shown in figure 4 corresponds to the general area of the carbonaterock province as used in this report (Plume, 1996, p. B5).

Continental-shelf deposits were still being laid down in the western Great Basin at the beginning of the Mesozoic Era. By Middle Triassic time, however, the continental margin had shifted westward so that the eastern Great Basin was an area of continental deposition and the western Great Basin an area of marine deposition (shelf and slope). The continental margin of western North America again shifted westward in Middle Jurassic time, and what is now the Great Basin became an area of continental deposition. Continental sedimentary rocks, interbedded with volcanic rocks of similar age, continued to form in basins of uncertain size and distribution into the middle or late Tertiary.

The size and distribution of sedimentary basins began to change drastically as early as Oligocene time. This change was coincident with the onset of the extensional faulting that began to form the present-day mountain ranges and basins of the Great Basin. The clastic deposits that accumulated while mountains and basins formed collectively are called basin-fill deposits. They range in age from middle Miocene or earlier through Holocene and consist of unsorted to sorted clay, silt, sand, gravel, and boulders. Some of the early basins appear to have had little or no relation to present-day basins; however, by the late Pliocene, the present distribution of mountains and basins was established.

The oldest rocks in the Great Basin are metamorphic rocks (mostly gneiss and schist) and granitic rocks of Precambrian age, commonly called Precambrian crystalline basement. Crystalline basement has been inferred to extend as far west as central Nevada (Stewart, 1980, p. 911). A wide range of intrusive igneous rocks was emplaced during the Mesozoic and Cenozoic Eras. Outcrop areas of these rocks range in size from a few square

\section{EXPLANATION}

$73 \mathrm{~B}$

Hydrographic area or subarea-Area shown by number only, subarea by number plus letter

Boundary of study area, Great Basin Regional Aquifer System

Boundary of major flow system-Dashed where uncertain

Boundary of hydrographic area or subarea miles to more than $100 \mathrm{mi}^{2}$. Interpretation of aeromagnetic data indicates that the subsurface extent of some intrusions is even larger.

The most recent period of volcanism began during the Eocene and has continued at differing intensities into the Pleistocene and possibly Holocene. Volcanic rocks can be found in nearly every mountain range of the Great Basin. Volcanic rocks also underlie and are interbedded with basin-fill deposits in much of the Great Basin.

\section{STRUCTURAL FEATURES}

During parts of the Paleozoic, Mesozoic, and possibly early Cenozoic Eras, the Great Basin was undergoing tectonic compression, and since the middle to late Tertiary, it has been undergoing tectonic extension. The dominant tectonic events of Paleozoic and early Mesozoic time were the Late Devonian and Early Mississippian Antler orogeny and the Late Permian and Early Triassic Sonoma orogeny. The major structural features that resulted from these two orogenies are the Roberts Mountains thrust (Antler orogeny) and the Golconda thrust (Sonoma orogeny) (fig. 5). The dominant tectonic event of Mesozoic age was the Sevier orogeny, which resulted in compression of the Earth's crust along a belt that extends from southern Idaho through central and western Utah, southern Nevada, and southeastern California. In the vicinity of Salt Lake City, as many as six individual thrust plates are recognized, and in the southern Great Basin, the orogenic belt is composed of four major thrust plates.

A structural feature of the Great Basin that may be related to more than one period of deformation is the Ruby Mountains metamorphic core complex (fig. 8). Two metamorphic core complexes are recognized within the Great Basin. Another is located along the margin of the Great Basin in northwestern Utah and south-central Idaho. The complexes are characterized by a ductilely deformed metamorphic-plutonic basement overlain by an unmetamorphosed terrane that is brittlely deformed along low-angle extensional faults. These two zones are separated by a surface of dislocation called a décollement or detachment that apparently is characteristic of all core complexes.

The dominant structural features of Cenozoic age in the Great Basin are the fault-block mountains and basins that formed as a result of extensional faulting. High-angle normal faults initially were perceived as the mechanism by which mountains and basins formed. Currently, however, 
TABLE 1.-Hydrographic areas and flow systems within study area, Great Basin Regional Aquifer System

[Numbers match those that are used to label areas in figure 2; major flow systems are shown in all-capital letters]]

\begin{tabular}{|c|c|c|c|}
\hline $\begin{array}{l}\text { Hydrographic- } \\
\text { area or-subarea } \\
\text { number }\end{array}$ & Name & $\begin{array}{l}\text { Hydrographic- } \\
\text { area or-subarea } \\
\text { number- } \\
\text { Continued }\end{array}$ & Name--Continued \\
\hline & CONTINENTAL LAKE SYSTEM & & HUMBOLDT SYSTEM-Continued \\
\hline 2 & Continental Lake Valley & 73 & Lovelock Valley \\
\hline 3 & Gridley Lake Valley & & A. Oreana Subarea \\
\hline & & & B. Upper and Lower Valley Areas \\
\hline 4 & VIRGIN VALLEX & 74 & White Plains \\
\hline \multirow[t]{2}{*}{7} & SWAN LAKE VALLEY & 131 & BUFFALO VALLEY \\
\hline & LONG VALLEY SYSTEM & 129 & BUENA VISTA VALLEY \\
\hline 8 & Massacre Lake Valley & & \\
\hline 9 & Long Valley & & GRANITE SPRINGS SYSTEM \\
\hline 12 & Mosquito Valley & 78 & Granite Springs Valley \\
\hline 15 & Boulder Valley & 79 & Kumiva Valley \\
\hline \multirow[t]{2}{*}{16} & DUCK LAKE VALLEY & 80 & WINNEMUCCA LAKE VALLEY \\
\hline & BLACK ROCK DESERT SYSTEM & & TRUCKEE SYSTEM \\
\hline 19 & Dry Valley & 81 & Pyramid Lake Valley \\
\hline 20 & Sano Valley & 82 & Dodge Flat \\
\hline 21 & Smoke Creek Desert & 83 & Tracy Segment \\
\hline 22 & San Emidio Desert & 84 & Warm Springs Valley \\
\hline 23 & Granite Basin & 85 & Spanish Springs Valley \\
\hline 24 & Hualapai Flat & 86 & Sun Valley \\
\hline 25 & High Rock Lake Valley & 87 & Truckee Meadows \\
\hline 26 & Mud Meadow & 88 & Pleasant Valley \\
\hline 27 & Summit Lake Valley & 89 & Washoe Valley \\
\hline 28 & Black Rock Desert & & \\
\hline 29 & Pine Forest Valley & & LEMMON VALLEY \\
\hline 30 & Kings River Valley & 92 & Lemmon Valley \\
\hline & A. Rio King Subarea & & A. Western Part \\
\hline & B. Sod House Subarea & & B. Eastern Part \\
\hline 31 & Desert Valley & 93 & Antelope Valley \\
\hline 32 & Silver State Valley & & \\
\hline \multirow[t]{6}{*}{33} & Quinn River Valley & 100 & COLD SPRING VALLEY \\
\hline & A. Orovada Subarea & & \\
\hline & B. McDermitt Subarea & & FERNLEY SINK SYSTEM \\
\hline & C. Oregon Canyon Subarea & 75 & Bradys Hot Springs Area \\
\hline & & 76 & Fernley Area \\
\hline & HUMBOLDT SYSTEM & 77 & Fireball Valley \\
\hline 42 & Marys River Area & & \\
\hline 43 & Starr Valley Area & & CARSON SYSTEM \\
\hline 44 & North Fork Area & 101 & Carson Desert \\
\hline 45 & Lamoille Valley & & A. Packard Valley \\
\hline 46 & South Fork Area & & B. Lahontan Valley \\
\hline 47 & Huntington Valley & 102 & Churchill Valley \\
\hline 48 & Dixie Creek-Tenmile Creek Area & 103 & Dayton Valley \\
\hline 49 & Elko Segment & & A. Carson Plains \\
\hline 50 & Susie Creek Area & & B. Stagecoach Valley \\
\hline 51 & Maggie Creek Area & 104 & Eagle Valley \\
\hline 52 & Marys Creek Area & 105 & Carson Valley \\
\hline 53 & Pine Valley & & \\
\hline 54 & Crescent Valley & & WALKER SYSTEM \\
\hline 55 & Carico Lake Valley & 106 & Antelope Valley \\
\hline 56 & Upper Reese River Valley & 107 & Smith Valley \\
\hline 57 & Antelope Valley & 108 & Mason Valley \\
\hline 58 & Middle Reese River Valley & 109 & East Walker Area \\
\hline 59 & Lower Reese River Valley & 110 & Walker Lake Valley \\
\hline 60 & Whirlwind Valley & & A. Schurz Subarea \\
\hline 61 & Boulder Flat & & B. Lake Subarea \\
\hline 62 & Rock Creek Valley & & C. Whiskey Flat-Hawthorne Subarea \\
\hline 63 & Willow Creek Valley & 121 & Soda Spring Valley \\
\hline 64 & Clovers Area & & B. Western Part \\
\hline 65 & Pumpernickel Valley & & C. Central Part \\
\hline 66 & Kelly Creek Area & & \\
\hline 67 & Little Humboldt Valley & & DIXIE VALLEY SYSTEM \\
\hline 68 & Hardscrabble Area & 124 & Fairview Valley \\
\hline 69 & Paradise Valley & 125 & Stingaree Valley \\
\hline 70 & Winnemucca Segment & 126 & Cowkick Valley \\
\hline 71 & Grass Valley & 127 & Eastgate Valley Area \\
\hline 72 & Imlay Area & 128 & Dixie Valley \\
\hline
\end{tabular}


TABLE 1.-Hydrographic areas and flow systems within study area, Great Basin Regional Aquifer System - Continued

[Numbers match those that are used to label areas in figure 2; major flow systems are shown in all-capital letter]

\begin{tabular}{|c|c|c|c|}
\hline $\begin{array}{c}\text { Hydrographic- } \\
\text { area or-subarea } \\
\text { number- } \\
\text { Continued }\end{array}$ & Name-Continued & $\begin{array}{l}\text { Hydrographic- } \\
\text { area or-subarea } \\
\text { number- } \\
\text { Continued }\end{array}$ & Name-Continued \\
\hline & DIXIE VALLEY SYSTEM - Continued & & DEATH VALLEY SYSTEM - Continued \\
\hline 130 & Pleasant Valley & 228 & Oasis Valley \\
\hline \multirow[t]{2}{*}{132} & Jersey Valley & 229 & Crater Flat \\
\hline & & 230 & Amargosa Desert \\
\hline \multirow[t]{2}{*}{133} & EDWARDS CREEK VALLEY & 240 & Chicago Valley \\
\hline & & 241 & California Valley \\
\hline \multirow[t]{2}{*}{134} & SMITH CREEK VALLEY & 242 & Lower Amargosa Valley \\
\hline & & 243 & Death Valley \\
\hline \multirow[t]{2}{*}{123} & RAWHIDE FLATS & 244 & Valjean Valley \\
\hline & GABBS VALLEY & 245 & Shadow Valley \\
\hline 122 & & & NEWARK VALLEY SYSTEM \\
\hline \multirow[t]{3}{*}{136} & MONTE CRISTO VALLEY & 154 & Newark Valley \\
\hline & & 155 & Little Smoky Valley \\
\hline & SOUTH-CENTRAL MARSHES & & A. Northern Part \\
\hline 113 & Huntoon Valley & & B. Central Part \\
\hline 114 & Teels Marsh Valley & & \\
\hline 117 & Fish Lake Valley & & RAILROAD VALLEY SYSTEM \\
\hline 118 & Columbus Salt Marsh Valley & 150 & Little Fish Lake Valley \\
\hline 119 & Rhodes Salt Marsh Valley & 155 & Little Smoky Valley \\
\hline 120 & Garfield Flat & 155 & C. Southern Part \\
\hline \multirow[t]{2}{*}{121} & Soda Spring Valley & 156 & Hot Creek Valley \\
\hline & A. Eastern Part & 173 & Railroad Valley \\
\hline 135 & Ione Valley & & B. Northern Part \\
\hline \multirow[t]{2}{*}{137} & Big Smoky Valley & & \\
\hline & A. Tonopah Flat & 170 & PENOYER VALLEY \\
\hline 141 & Ralston Valley & 170 & 1 LTV U ILA VRLLE I \\
\hline 142 & Alkali Spring Valley & & INDEPENDENCE VALLEY SYSTEM \\
\hline 143 & Clayton Valley & 177 & Clover Valley \\
\hline 149 & Stone Cabin Valley & 188 & Independence Valley (Pequop Valley) \\
\hline 138 & GRASS VALLEY & & RUBY VALLEY SYSTEM \\
\hline \multirow{3}{*}{137} & & 176 & Ruby Valley \\
\hline & BIG SMOKY VALLEY & 178 & Butte Valley \\
\hline & B. Northern Part & & A. Northern Part \\
\hline \multirow{5}{*}{$\begin{array}{l}139 \\
140\end{array}$} & DIAMOND VALLEY SYSTEM & & COLORADO SYSTEM \\
\hline & Kobeh Valley & 164 & Ivanpah Valley \\
\hline & Monitor Valley & & A. Southern Part \\
\hline & A. Northern Part & & B. Northern Part \\
\hline & B. Southern Part & 165 & Jean Lake Valley \\
\hline 151 & Antelope Valley (Eureka and Nye) & $\begin{array}{l}105 \\
166\end{array}$ & Hidden Valley (South) \\
\hline 152 & Stevens Basin & $\begin{array}{l}166 \\
167\end{array}$ & Eldorado Valley \\
\hline \multirow[t]{3}{*}{153} & Diamond Valley & 161 & Coal Valley \\
\hline & & 172 & Garden Valley \\
\hline & DEATH VALLEX SYSTEM & 174 & Jakes Valley \\
\hline 144 & Lida Valley & 175 & Long Valley \\
\hline 145 & Stonewall Flat & 180 & Cave Valley \\
\hline 146 & Sarcobatus Flat & $\begin{array}{l}180 \\
181\end{array}$ & Dry Lake Valley \\
\hline 147 & Gold Flat & $\begin{array}{l}181 \\
182\end{array}$ & Delamar Valley \\
\hline 148 & Cactus Flat & & $\begin{array}{l}\text { Delamar Valley } \\
\text { Lake Valley }\end{array}$ \\
\hline 157 & Kawich Valley & 183 & \\
\hline \multirow[t]{3}{*}{158} & Emigrant Valley & 198 & Dry Valley \\
\hline & A. Groom Lake Valley & 199 & Rose Valley \\
\hline & B. Papoose Lake Valley & 200 & Eagle Valley \\
\hline 159 & Yucca Flat & 201 & Spring Valley \\
\hline 160 & Frenchman Flat & 202 & Patterson Valley \\
\hline 161 & Indian Springs Valley & 203 & Panaca Valley \\
\hline 162 & Pahrump Valley & 204 & Clover Valley \\
\hline 168 & Three Lakes Valley (Northern Part) & 205 & Lower Meadow Valley Wash \\
\hline 169 & $\begin{array}{l}\text { Three Lakes valley (INorthern Iart) } \\
\text { Tikapoo Valley }\end{array}$ & 206 & Kane Springs Valley \\
\hline & A. Northern part & 207 & White River Valley \\
\hline & $\begin{array}{l}\text { A. Northern part } \\
\text { B. Southern Part }\end{array}$ & 208 & Pahroc Valley \\
\hline 173 & Railroad Valley & 209 & Pahranagat Valley \\
\hline & A. Southern Part & 210 & Coyote Spring Valley \\
\hline 211 & Three Lakes Valley (Southern Part) & 212 & Las Vegas Valley \\
\hline 225 & Mercury Valley & 215 & Black Mountains Area \\
\hline 226 & Rock Valley & 216 & Garnet Valley \\
\hline 227 & Fortymile Canyon & 217 & Hidden Valley (North) \\
\hline & $\begin{array}{l}\text { Fortymile Canyon } \\
\text { A. Jackass Flats }\end{array}$ & 218 & California Wash \\
\hline & A. Buckboard Mesa & 219 & Muddy River Springs Area \\
\hline
\end{tabular}


TABLE 1.-Hydrographic areas and flow systems within study area, Great Basin Regional Aguifer System —Continued

[Numbers match those that are used to label areas in figure 2; major flow systems are shown in all-capital letters]

\begin{tabular}{|c|c|c|c|}
\hline $\begin{array}{l}\text { Hydrographic- } \\
\text { area or-subarea } \\
\text { number- } \\
\text { Continued }\end{array}$ & Name-Continued & $\begin{array}{l}\text { Hydrographic- } \\
\text { area or-subarea } \\
\text { number- } \\
\text { Continued }\end{array}$ & Name-Continued \\
\hline & COLORADO SYSTEM - Continued & \multirow{3}{*}{260} & GREAT SALT LAKE SYSTEM \\
\hline 220 & Lower Moapa Valley & & Park Valley \\
\hline 221 & Tule Desert & & B. East Park Valley \\
\hline 222 & Virgin River Valley & \multirow[t]{2}{*}{261} & Great Salt Lake Desert \\
\hline & & & B. East Part \\
\hline & GOSHUTE VALLEY SYSTEM & 262 & Tooele Valley \\
\hline 178 & Butte Valley & 263 & Rush Valley \\
\hline & B. Southern Part & 264 & Cedar Valley \\
\hline 179 & Steptoe Valley & \multirow{3}{*}{265} & Utah Valley Area \\
\hline 187 & Goshute Valley & & A. Goshen Valley \\
\hline \multirow[t]{2}{*}{163} & MESQUTTE VALLEY & & $\begin{array}{l}\text { B. Southern Utah Valley } \\
\text { C. Northern Utah Valley }\end{array}$ \\
\hline & GREAT SALT LAKE DESERT SYSTEM & 266 & Northern Juab Valley \\
\hline 251 & Grouse Creek Valley & 267 & Salt Lake Valley \\
\hline 252 & Pilot Valley & 268 & East Shore Area \\
\hline 253 & Deep Creek Valley & 269 & West Shore Area \\
\hline 254 & Snake Valley & 270 & Skull Valley \\
\hline 255 & Pine Valley & 271 & Sink Valley \\
\hline 256 & Wah Wah Valley & 272 & Cache Valley \\
\hline 257 & Tule Valley & 273 & Malad-Lower Bear River Area \\
\hline 258 & Fish Springs Flat & 274 & Pocatello Valley \\
\hline 259 & Dugway-Government Creek Valley & 275 & Blue Creek Valley \\
\hline 260 & Park Valley & $\begin{array}{l}2 / 3 \\
276\end{array}$ & Hansel and Northern Rozel Flat \\
\hline & A. West Park Valley & 277 & Promontory Mountains Area \\
\hline 261 & Great Salt Lake Desert & 278 & Curlew Valley \\
\hline & A. West Part & $\begin{array}{l}278 \\
279\end{array}$ & Great Salt Lake \\
\hline 184 & Spring Valley & & Gileat Jamt Lane \\
\hline 185 & Tippett Valley & & SEVIER LAKE SYSTEM \\
\hline 186 & Antelope Valley & & Beryl-Enterprise Area \\
\hline & A. Southern Part & 280 & Parowan Valley \\
\hline & B. Northern Valley & 281 & Cedar City Valley \\
\hline 189 & Thousand Springs Valley & 282 & Beaver Valley \\
\hline & A. Herrell Siding-Brush Creek Area & 283 & Milford Area \\
\hline & B. Toano-Rock Spring & 284 & Leamington Canyon \\
\hline & C. Rocky Butte Area & 285 & \\
\hline & D. Montello-Crittenden Creek Area & 286 & Pavant Valley \\
\hline 191 & Pilot Creek Valley & 287 & Sevier Desert \\
\hline
\end{tabular}

three types of normal faults are recognized: (1) high-angle normal faults, (2) listric normal faults, which curve and flatten with depth, and (3) low-angle normal faults that generally have placed younger rocks over older ones and commonly are called detachments. These three types of faults have been found in all parts of the Great Basin.

The Walker Lane belt, which is mostly in western Nevada, is an area of irregular topographic trends that contrast with the more regular north-northeast trends observed in the rest of the Great Basin. The belt is a structurally complex zone characterized by several structural blocks, each with styles of deformation and structural features that do not extend to adjacent blocks (Stewart, 1988, p. 686).
EXPLANATION

Estimated ground-water withdrawals for 1975 , by hydrographic area or subarea, in acre-feet

999 or less

1,000 to 4,999

5,000 to 19,999

20,000 to 79,999

80,000 or greater

Boundary of study area, Great Basin Regional Aquifer System

Boundary of hydrographic area or subarea (fig. 2) 


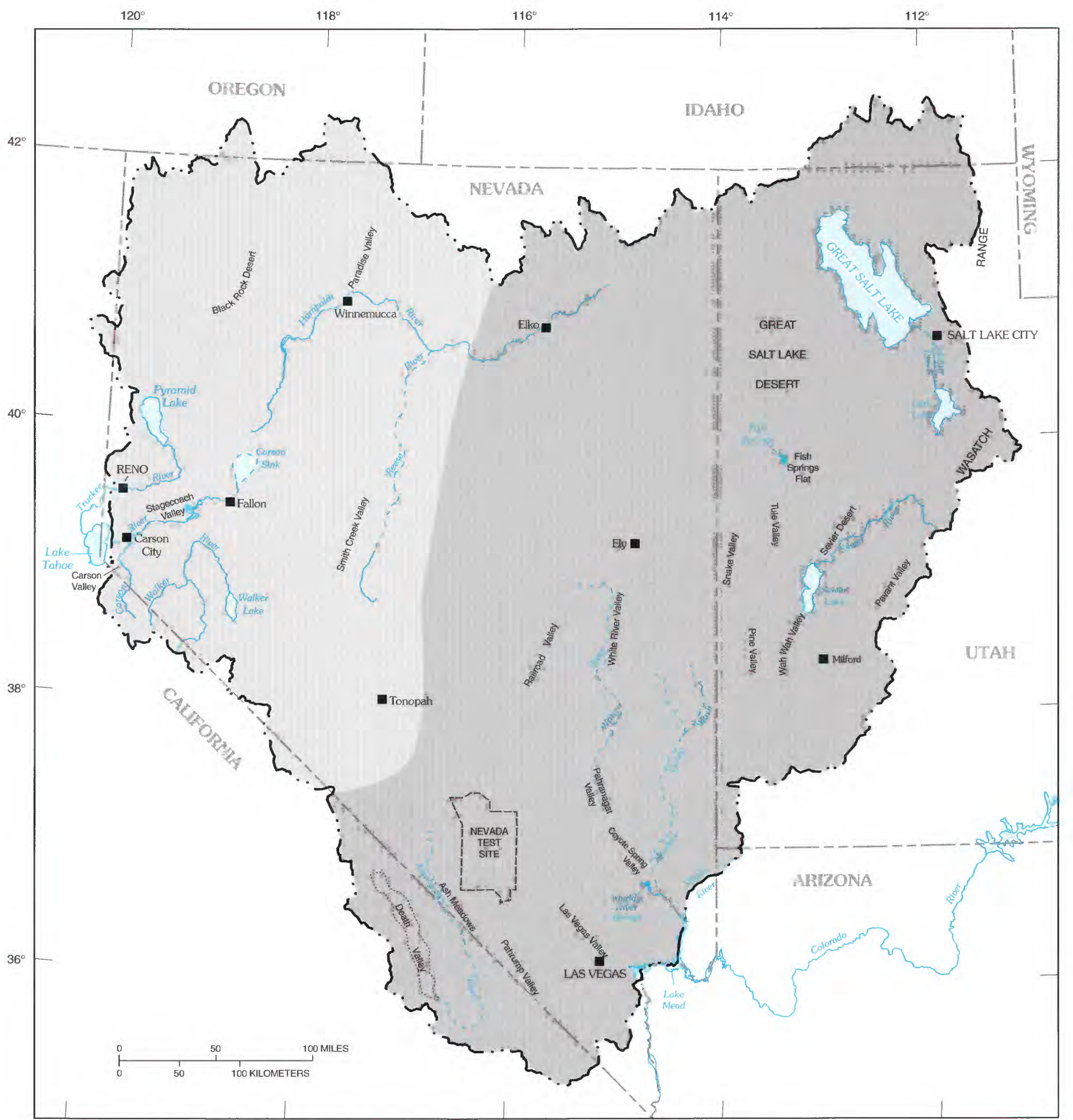

Base from U.S. Geological Survey digital data, 1:100,000, 1978-88, and 1:250,000, 1987 Albers Equal-Area Conic projection

Standard parallels $29^{\circ} 30^{\prime}$ and $45^{\circ} 30^{\prime}$, central meridian $-114^{\circ} 00^{\prime}$

FIGURE 4.-Occurrence of depositional facies of early Mesozoic and older rocks in Great Basin study area. Modified after Plume (1996, p. B4). 


\section{HYDROGEOLOGY}

The consolidated rocks and unconsolidated to semiconsolidated deposits that underlie the Great Basin were grouped into several hydrogeologic units that either store and transmit ground water in regional aquifer systems or impede the movement of ground water (Plume, 1996). Hydrogeologic units in the western Great Basin are (1) sedimentary and igneous rocks of late Precambrian to Quaternary age, (2) older basin-fill deposits (Miocene and Pliocene), and (3) younger basin-fill deposits (Pliocene to Holocene). Hydrogeologic units in the eastern Great Basin are (1) metamorphic, igneous, and sedimentary rocks of Precambrian and Early Cambrian age; (2) carbonate and clastic sedimentary rocks of Middle Cambrian to Early Triassic age, (3) sedimentary and igneous rocks of Middle Triassic to Quaternary age, (4) older basin-fill deposits (Miocene and Pliocene), and (5) younger basinfill deposits (Pliocene to Holocene). The two main aquifer systems recognized in the Great Basin consist of the basinfill units (basin-fill aquifers) and the carbonate and clastic sedimentary rocks of Middle Cambrian to Early Triassic age (carbonate-rock aquifers). The other units mostly impede ground-water flow, although several exceptions to this were described by Plume (1996). The distribution of the basin-fill aquifers, the carbonate-rock aquifers, and the rocks that impede ground-water flow is shown in figure 6. The relation of these units to Plume's (1996) hydrogeologic units is presented in table 2 .

\section{CARBONATE-ROCK AQUIFERS}

The eastern Great Basin is underlain by thick sections of marine sedimentary rocks that can be separated broadly into two parts: an upper part of Middle Cambrian to Lower Triassic carbonate rocks with minor amounts of clastic sedimentary rocks and a lower part of upper Precambrian and Lower Cambrian clastic sedimentary rocks. The carbonate and clastic sedimentary rocks constitute an extensive hydrogeologic unit that underlies the entire eastern two-thirds of the Great Basin (fig. 6). The western limit of this unit, as adopted for this report, is the western-

\section{EXPLANATION}

\section{Western depositional facies}

Eastern and transitional depositional faciesCorresponds to carbonate-rock province

- - B - Boundary of study area, Great Basin Regional Aquifer System most extent of Stewart and Carlson's (1978) carbonate (eastern) assemblage. General lithology of this hydrogeologic unit and specific formations included in the unit were summarized by Plume (1996, 34-40). The overall stratigraphic thickness of the unit ranges from about 5,000 $\mathrm{ft}$ to nearly $30,000 \mathrm{ft}$. However, stratigraphic thickness does not necessarily indicate the depth to which ground water circulates, because structural deformation of the section can result in apparent thicknesses that differ markedly from true stratigraphic thickness and because the carbonate rocks may not be permeable throughout their entire stratigraphic thickness.

The carbonate-rock aquifers as defined by Dettinger (1989a, p. 5-7) are composed mostly of the carbonate-rock sequence just described. The carbonate-rock aquifer system generally is bounded laterally by the limits of the carbonate-rock province shown in figure 5 . The aquifer system is underlain by metamorphic, igneous, and sedimentary rocks of Precambrian and Early Cambrian age. The carbonate-rock aquifers include what Winograd and Thordarson (1975, p. 10-11) called the upper and lower carbonate aquifers and upper clastic aquitard in the south-central Great Basin and what Plume and Carlton (1988) described as the upper and lower parts of the carbonate-rock aquifer and intervening clastic sedimentary rocks in the eastern Great Basin.

Fractures and joints that may have been widened by solution are the principal openings that store and transmit ground water in the carbonate-rock aquifers. Three types of porosity have been recognized in carbonate rocks in south-central Nevada-intercrystalline, vug, and fracture, the third being most important to the movement and storage of ground water (Winograd and Thordarson, 1975, p. 14-40). Typical fracture porosities determined from laboratory measurement of core samples range from 0 to 1 percent and average 0.1 percent, whereas fracture porosities estimated from geophysical logs range from 0 to as much as 28 percent, although the upper limit commonly is closer to 10 percent (Winograd and Thordarson, 1975 , p. 18-19). Berger (1992, p. 18) determined a mean total porosity of 4.7 percent from analysis of geophysical logs of five test wells in carbonate-rock aquifers in and near Coyote Spring Valley in southern Nevada. An effective porosity of 9 percent was determined for Paleozoic dolomite at the Nevada Test Site of southern Nevada using measurements of Earth tides and barometric fluctuations (Galloway, 1986). Values of porosity recorded on American Stratigraphic Company (AMSTRAT) logs of petroleum-exploration wells drilled in the eastern Great Basin ranged from 0 to more than 20 percent, although the upper limit of the range commonly is less than 10 percent (Plume, 1996, p. 41-58). 


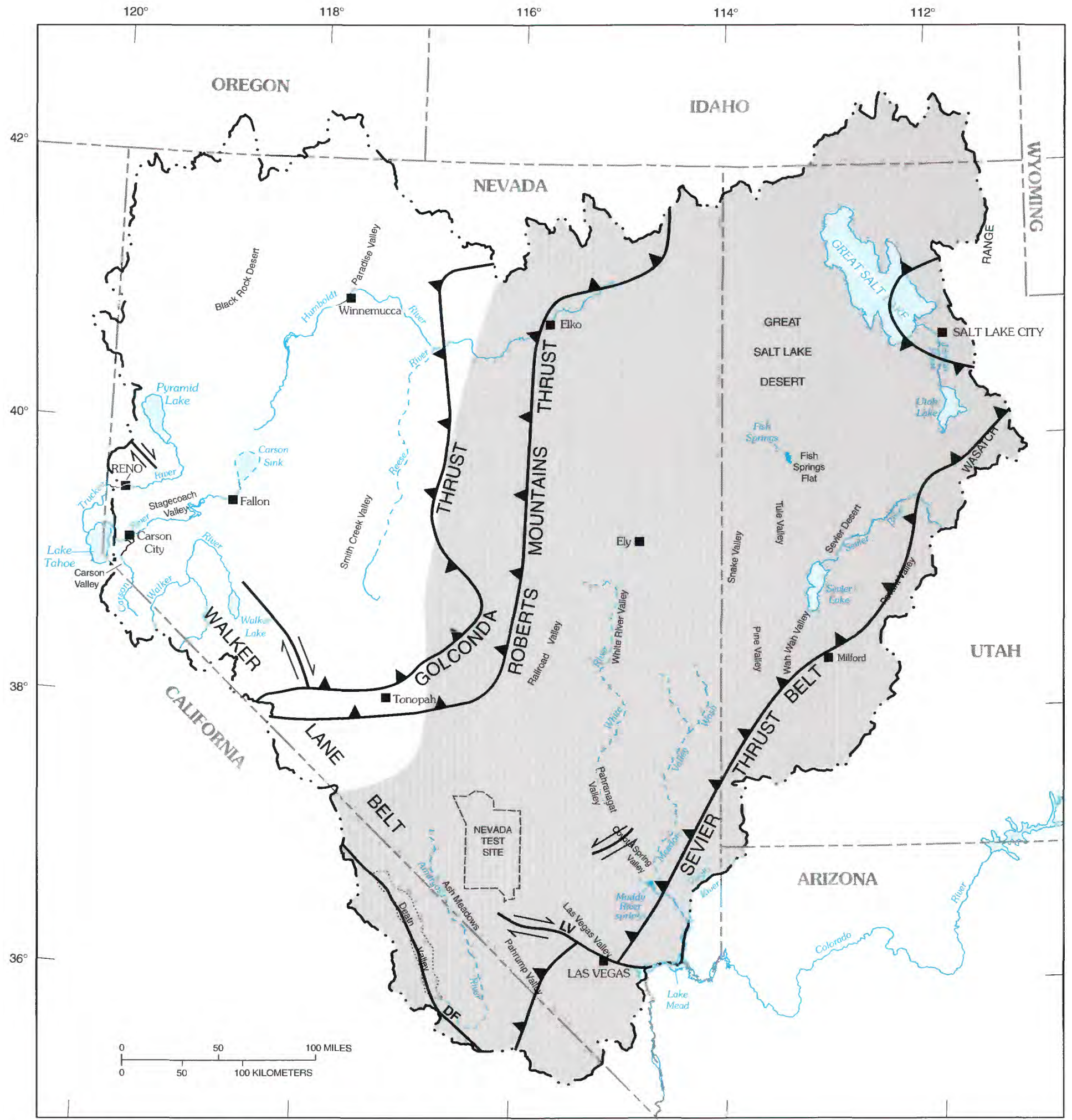

Base from U.S. Geological Survey digital data, 1:100,000, 1978-88, and 1:250,000, 1987 Albers Equal-Area Conic projection

Standard parallels $29^{\circ} 30^{\prime}$ and $45^{\circ} 30^{\prime}$, central meridian $-114^{\circ} 00^{\circ}$

FIGURE 5.-Selected geologic features of Great Basin study area (Stewart and Carlson, 1978; Hintze, 1980; and Stewart, 1980, p. 10-64). DF, Death Valley-Furnace Creek fault zone; LV, Las Vegas shear zone. 
Transmissivity of carbonate-rock aquifers has been determined at several sites in the eastern Great Basin. Values of hydraulic conductivity estimated from 23 aquifer tests (Winograd and Thordarson, 1975, p. 22-23; Bunch and Harrill, 1984, p. 119; Dettinger and others, 1995) distributed over much of the Great Basin study area ranged from 0.005 to $900 \mathrm{ft} / \mathrm{d}$ and had a mean of $80 \mathrm{ft} / \mathrm{d}$ and a median of $0.8 \mathrm{ft} / \mathrm{d}$ (Plume, 1996, p. B13). The range of values indicates that these aquifers are very heterogeneous. AMSTRAT logs analyzed by Plume (1996) indicate that zones of high porosity commonly are less than $100 \mathrm{ft}$ thick and are separated by hundreds to thousands of feet of low-porosity rock. One possible interpretation is that zones of low porosity identified on the AMSTRAT logs are characterized by the types of microscopic porosity seen in thin sections and presumably by low values of hydraulic conductivity. Another is that zones of high porosity and hydraulic conductivity are restricted to relatively narrow fault or fracture zones among much wider zones of low porosity.

In addition to the aquifer tests at wells, transmissivity has been estimated for the carbonate-rock aquifers by using Darcy's law. Using values of underflow estimated from water budgets, estimated aquifer widths, and hydraulic gradients computed from ground-water-level measurements, Eakin (1966, p. 266) computed values of transmissivity of 30,000 and $20,000 \mathrm{ft}^{2} / \mathrm{d}$ for the carbonate-rock aquifer at the north and south ends of White River Valley (Nevada), respectively, and $30,000 \mathrm{ft}^{2} / \mathrm{d}$ for the middle part of Coyote Spring Valley (also in Nevada). Using a similar approach and aeromagnetic data, Plume (1988b) revised the estimate of regional transmissivity for the carbonate-rock aquifer at the north end of White River Valley to $20,000 \mathrm{ft}^{2} / \mathrm{d}$.

\section{EXPLANATION}

Carbonate-rock province-Shows approximate extent of Middle Cambrian to Lower Triassic carbonate rocks and associated clastic rocks. West boundary (modified from Plume, 1996, p. B4) corresponds to easternmost extent of Paleozoic transitional-assemblage sedimentary rocks as defined by Stewart and Carlson (1978) and by Stewart (1980, p. 20).

\section{- - B - Boundary of study area, Great Basin Regional} Aquifer System

Strike-slip fault-Arrows indicate relative movement

Thrust fault-Teeth on upper plate

\section{BASIN-FILL AQUIFERS}

Each hydrographic area in the region is underlain by a structural basin partly filled with clastic material eroded from the adjacent mountains. These deposits form basinfill aquifers that are bounded by the consolidated rocks of the structural basin. Some are connected hydraulically to a similar aquifer in an adjacent hydrographic area by basin-fill deposits or permeable consolidated rocks. In the eastern Great Basin, most are connected hydraulically to adjacent or underlying carbonate-rock aquifers.

The geometry of a basin and the composition of the basin-fill deposits essentially define its hydrogeologic framework. Basin-fill deposits typically consist of an older unit of upper Miocene and lower Pliocene deposits and a younger unit of upper Pliocene to Holocene deposits (Plume, 1996). Younger basin fill consists of unconsolidated to semiconsolidated deposits of sand, silt, gravel, and clay and make up the uppermost part of the fill in most basins. The sand and gravel deposits yield water readily to wells and are the aquifers most commonly developed. The subsurface extent of the younger basin fill is uncertain because it is difficult to distinguish from the older basin fill solely on the basis of well logs. In addition, the distinction between older and younger basin fill has not always been emphasized in geologic studies and the relations of the units are not always easy to understand (Stewart, 1980, p. 95). Consequently, hereafter in this report the younger and older basin-fill deposits collectively are called basin-fill deposits. Gates (1984, p. 243) reported that in most places in northwestern Utah probably only the upper 500 to $1,500 \mathrm{ft}$ of the basin fill is permeable and contains potable water.

Hydraulic conductivities of basin-fill deposits differ laterally and vertically, owing to changes in composition of the deposits. The range of conductivity values for aquifertest results of 17 wells is 0.02 to $140 \mathrm{ft} / \mathrm{d}$ as reported by Bunch and Harrill (1984, p. 115-118). That range is probably reasonable for basin-fill deposits that have not been reworked by a perennial stream. The mean and median values for all 17 wells are 78 and $83 \mathrm{ft} / \mathrm{d}$, respectively. Ranges of hydraulic conductivity were compiled for broad physiographic settings by Plume (1996, p. B16B17), who concluded that values of hydraulic conductivity should be larger toward basin margins and smaller, and within broader ranges, near the basin axis. Similar trends in composition and in hydraulic-conductivity values apply to basins with a perennial or nearly perennial stream. One exception is where those deposits of past and present stream flood plains include reworked materials along the axis of a basin. These materials can be much more productive aquifers than comparable deposits that have not been reworked by a stream. 


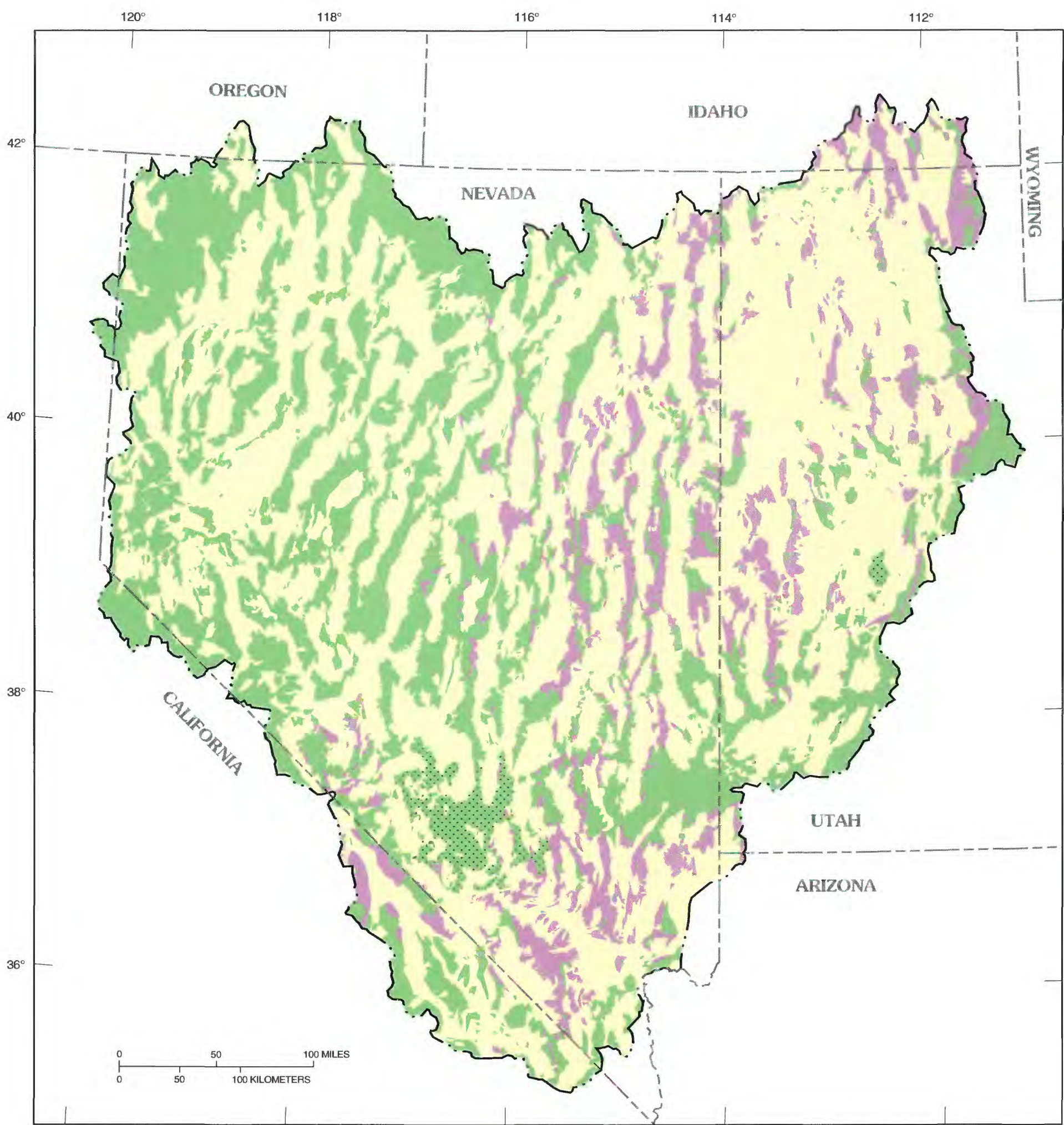

Base from U.S. Geological Survey digital data, 1:100,000, 1978-88, and 1:250,000, 1987 Albers Equal-Area Conic projection 
Geometries of structural basins range from simple to complex, depending on the tectonic history of the basins. Thickness of fill generally ranges from $0 \mathrm{ft}$ at basin margins to greater than $10,000 \mathrm{ft}$ in a few areas; the average thickness is at least several thousand feet. Idealized sections of six basins selected to represent the more common basin geometries in the Great Basin are shown in figure 7. Two broad types of basin geometry are shown: structural basins that are relatively symmetrical with respect to their topographic basins and structural basins that are asymmetrical. Seismic-reflection data for other valleys in Nevada and western Utah (Anderson and others, 1983) indicate that basin geometries can be more complex than the ones shown in figure 7 . Nonetheless, the basic shapes defined by Anderson and others (1983, p. 1067) generally can be categorized as either relatively symmetrical or asymmetrical.

\section{VOLCANIC-ROCK AQUIFERS}

Except for carbonate-rock aquifers and basin-fill aquifers, other hydrogeologic units in the Great Basin generally confine the movement of ground water. The most notable exceptions are some Cenozoic volcanic-rock units in parts of the Great Basin. Volcanic rocks have been recognized as aquifers in relatively few areas in spite of their prevalence in the Great Basin. These areas include the Fallon area, western Nevada (Glancy, 1986); the Nevada Test Site, southern Nevada (Winograd and Thordarson, 1975);

\section{EXPLANATION}

Basin fill-Mixed alluvial, colluvial, and lacustrine basin-fill deposits; some interbedded volcanic deposits. Most water pumped by wells is derived from deposits of gravel or sand or both. Forms basin-fill aquifers

Carbonate rocks-Sequences of permeable carbonate and clastic sedimentary rocks. Highest yielding aquifers are in areas of fractured carbonate rocks, where some fractures may have been enlarged by dissolution. Form carbonaterock aquifers

Noncarbonate consolidated rocks-Fine-grained clastic rocks, metamorphic rocks, intrusive rocks, and most volcanic rocks. Generally function as relative barrier to ground-water flow. Stipple indicates very fractured volcanic rocks (some basalts and other flow rocks and some welded tuffs) that form highly permeable aquifers

Boundary of study area, Great Basin Regional Aquifer System part of central Nevada (Fiero, 1968); part of southeastern Nevada (Emme, 1986); and the Pavant Valley, western Utah (Mower, 1965). Basalt flows enclosed by basin-fill deposits form important aquifers in the Fallon area and in Pavant Valley. Lava flows and welded tuffs form important aquifers at the Nevada Test Site, whereas ash-flow and air-fall tuffs have low permeability and generally act as confining units. In other parts of the study area, such as Railroad Valley, most volcanic rocks have low permeability and do not readily transmit ground water.

\section{BARRIERS TO REGIONAL GROUND-WATER FLOW}

Ground-water flow is affected by a wide variety of rock units that do not readily transmit ground water. These barriers confine ground-water flow in both vertical and horizontal directions. In the carbonate-rock aquifers, they form parts of boundaries between flow regions (as defined by Prudic and others, 1995) and form zones of low permeability, and in the western Great Basin and to a lesser extent the eastern Great Basin, they bound the structural basins that contain basin-fill aquifers. The rocks that form these barriers and low-permeability zones are included in "noncarbonate consolidated rocks" in figure 6.

The importance of any of the rock types as barriers to flow is not fully understood because their subsurface extents are not always indicated by study of outcrops or geologic maps. Precambrian crystalline basement and Jurassic to Tertiary granitic rocks contain magnetic minerals, and the magnetization contrasts between these and adjacent, less magnetic rocks are generally sufficient that the subsurface geometry of the more magnetic bodies (basement rocks and younger granitic rocks) can be approximated by analyzing aeromagnetic data. Plume (1996) used aeromagnetic data to evaluate the occurrence and subsurface distribution of these bodies. Outcrop areas of rocks that are potential barriers to ground-water flow and the subsurface extent of magnetic-source bodies in the eastern Great Basin are shown in figure 8. Potential barriers to regional ground-water flow include rocks of Precambrian and Early Cambrian age-clastic sedimentary rocks, crystalline basement, and the metamorphic core complexes in the Snake Range and Ruby Mountains in Nevada-as well as granitic rocks of Jurassic to Tertiary age. The magnetic-source bodies shown in figure 8 probably consist of either Precambrian crystalline basement or Jurassic to Tertiary granitic rocks. They are considered to be subsurface barriers to deep, regional ground-water flow. 
TABLE 2.-Aquifers and confining units in Great Basin study area

[Modified from Plume (1996, p. B34-B40)]

\begin{tabular}{|c|c|c|c|}
\hline $\begin{array}{l}\text { Aquifer or } \\
\text { confining unit }\end{array}$ & Hydrogeologic unit & Generalized geology & Water-bearing characteristics \\
\hline $\begin{array}{l}\text { Basin-fill } \\
\text { aquifers. }\end{array}$ & $\begin{array}{l}\text { Younger basin-fill deposits of late } \\
\text { Pliocene to Holocene age and } \\
\text { older basin-fill deposits of middle } \\
\text { Miocene to early Pliocene age. }\end{array}$ & $\begin{array}{l}\text { Younger basin-fill deposits consist of unconsoli- } \\
\text { dated to semiconsolidated deposits in alluvial } \\
\text { fans and pediments (unsorted to poorly sorted } \\
\text { silt, sand, gravel, and boulders), in valley low- } \\
\text { lands and playas (poorly sorted clay, silt, sand, } \\
\text { and gravel), and in stream flood plains (moder- } \\
\text { ately sorted to well-sorted beds of silt and clay } \\
\text { or sand and gravel). Older basin-fill deposits } \\
\text { consist of semiconsolidated to consolidated } \\
\text { fanglomerate, sandstone, siltstone, mudstone, } \\
\text { limestone, and interbedded volcanic rocks. }\end{array}$ & $\begin{array}{l}\text { Younger and older basin-fill deposits, collectively } \\
\text { referred to as basin fill, form basin-fill aquifers and } \\
\text { yield much of the ground water used in Great Basin. } \\
\text { Estimates of hydraulic conductivity for basin-fill } \\
\text { deposits excluding flood-plain deposits ranged } \\
\text { from } 0.02 \text { to } 140 \text { feet per day and averaged } 78 \text { feet } \\
\text { per day. Hydraulic conductivities of flood-plain } \\
\text { deposits were estimated to range from } 16 \text { to } 1,100 \\
\text { feet per day and averaged } 130 \text { feet per day. }\end{array}$ \\
\hline $\begin{array}{l}\text { Carbonate-rock } \\
\text { aquifers. }\end{array}$ & $\begin{array}{l}\text { Carbonate and clastic sedimentary } \\
\text { rocks of Middle Cambrian to Early } \\
\text { Triassic age in eastern Great Basin. }\end{array}$ & $\begin{array}{l}\text { Interbedded limestone, dolomite, sandstone, and } \\
\text { shale. Contains some beds of conglomerate } \\
\text { and gypsum. }\end{array}$ & $\begin{array}{l}\text { Unit forms carbonate-rock aquifers in eastern Great } \\
\text { Basin. Ground water is transmitted mostly along } \\
\text { joints and fractures. Estimates of hydraulic conduc- } \\
\text { tivity range from } 0.0005 \text { to } 900 \text { feet per day; higher } \\
\text { values correspond to fault or fracture zones and } \\
\text { lower values to relatively unfractured rock. }\end{array}$ \\
\hline $\begin{array}{l}\text { Volcanic-rock } \\
\text { aquifers. }\end{array}$ & $\begin{array}{l}\text { Subunit of sedimentary and igneous } \\
\text { rocks of late Precambrian to Qua- } \\
\text { ternary age in western Great Basin } \\
\text { and of sedimentary and igneous } \\
\text { rocks of Middle Triassic to Qua- } \\
\text { ternary age in eastern Great Basin. }\end{array}$ & $\begin{array}{l}\text { Flows and flow breccias, which range in com- } \\
\text { position from basalt to rhyolite, and silicic } \\
\text { welded tuffs. Where these rocks are highly } \\
\text { fractured, they form aquifers instead of con- } \\
\text { fining units. }\end{array}$ & $\begin{array}{l}\text { Localized conditions of high permeability are charac- } \\
\text { teristic of this unit. A basalt aquifer interbedded } \\
\text { with younger basin-fill deposits at Fallon, Nev., has } \\
\text { hydraulic conductivities estimated to range from } \\
130 \text { to } 3,100 \text { feet per day. Basalts interbedded with } \\
\text { basin-fill deposits in Pavant Valley, Utah, have } \\
\text { estimated hydraulic conductivities that range from } \\
370 \text { to } 46,000 \text { feet per day. Lava flows and welded } \\
\text { tuffs at Nevada Test Site (south-central Nevada) } \\
\text { have hydraulic conductivities that range from } 1.5 \text { to } \\
17 \text { feet per day. }\end{array}$ \\
\hline $\begin{array}{l}\text { Confining units } \\
\text { and relatively } \\
\text { impermeable } \\
\text { barriers. }\end{array}$ & $\begin{array}{l}\text { Sedimentary and igneous rocks of } \\
\text { late Precambrian to Quaternary } \\
\text { age in western Great Basin; sedi- } \\
\text { mentary and igneous rocks of } \\
\text { Middle Triassic to Quaternary } \\
\text { age and metamorphic, igneous, } \\
\text { and sedimentary rocks of late } \\
\text { Precambrian and Early Cambrian } \\
\text { age in eastern Great Basin. }\end{array}$ & $\begin{array}{l}\text { Fine-grained sedimentary rocks, most volcanic } \\
\text { rocks, intrusive rocks, metamorphic rocks, and } \\
\text { older crystalline basement. }\end{array}$ & $\begin{array}{l}\text { Unit is poorly permeable barrier to ground-water } \\
\text { flow. Inhibits flow between hydrographic basins } \\
\text { and does not readily transmit ground water. May } \\
\text { form base of carbonate-rock aquifers. }\end{array}$ \\
\hline
\end{tabular}

\section{EXPLANATION}

\section{Sedimentary basin fill}

Younger (Quaternary to Tertiary) - Unconsolidated to semiconsolidated deposits

Older (Tertiary) —-Semiconsolidated to consolidated deposits

Other consolidated rocks (Quaternary to Precambrian)Sedimentary, igneous, and metamorphic rocks underlying basin-fill deposits

Contact-Approximately located

- - Fault-Dashed where approximate. Arrows indicate direction of relative movement

$\longmapsto \quad$ Section line on index map-Reduced scale 


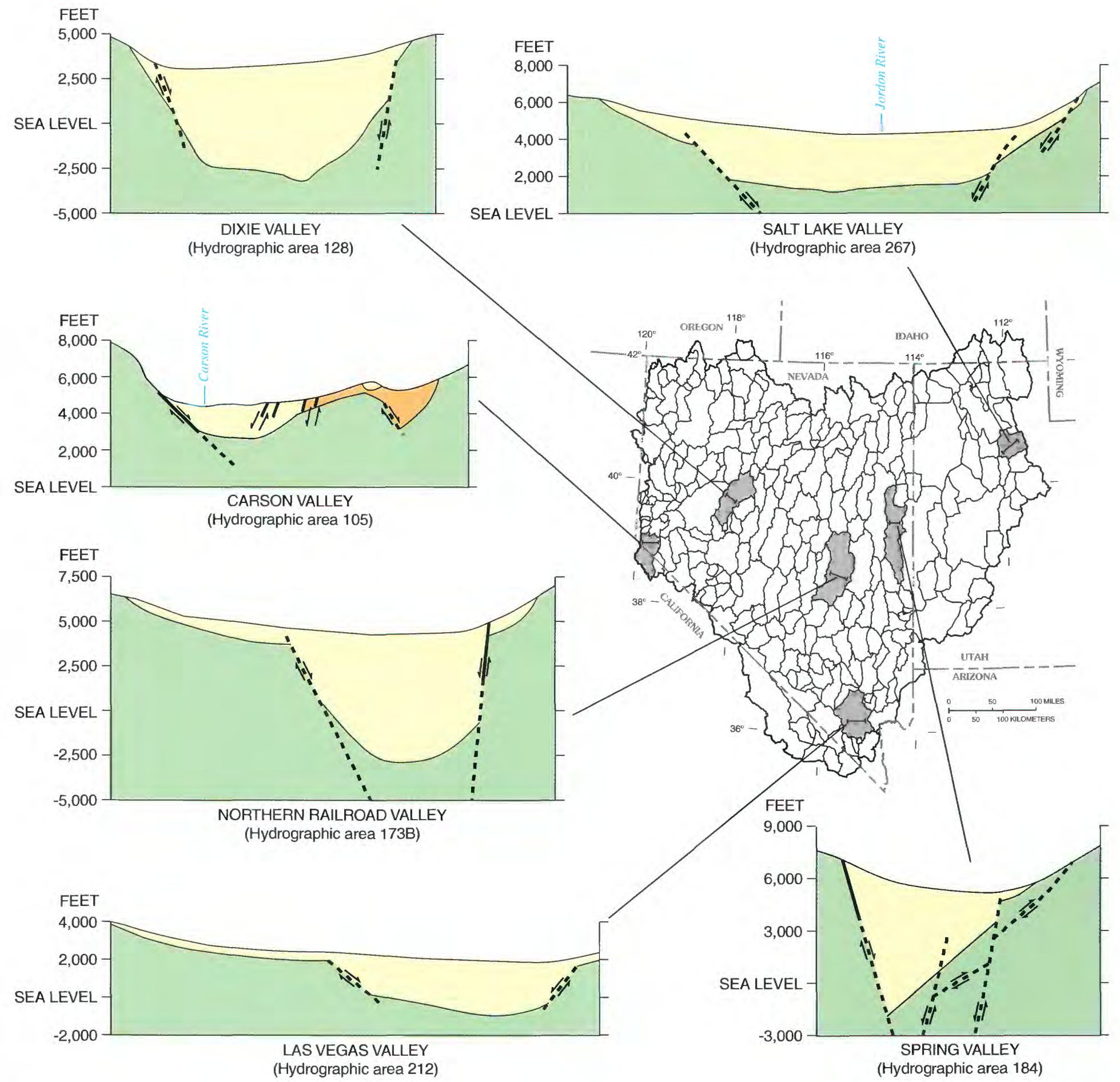

FIGURE 7.-Idealized sections showing basin geometry for six representative hydrographic areas (fig. 2). Vertical exaggeration, all sections, $\times 4$. Index map shows locations of six areas within Great Basin study area; for base credit and geographic detail, see figures 1 and 2. Modified from Plume (1996). 


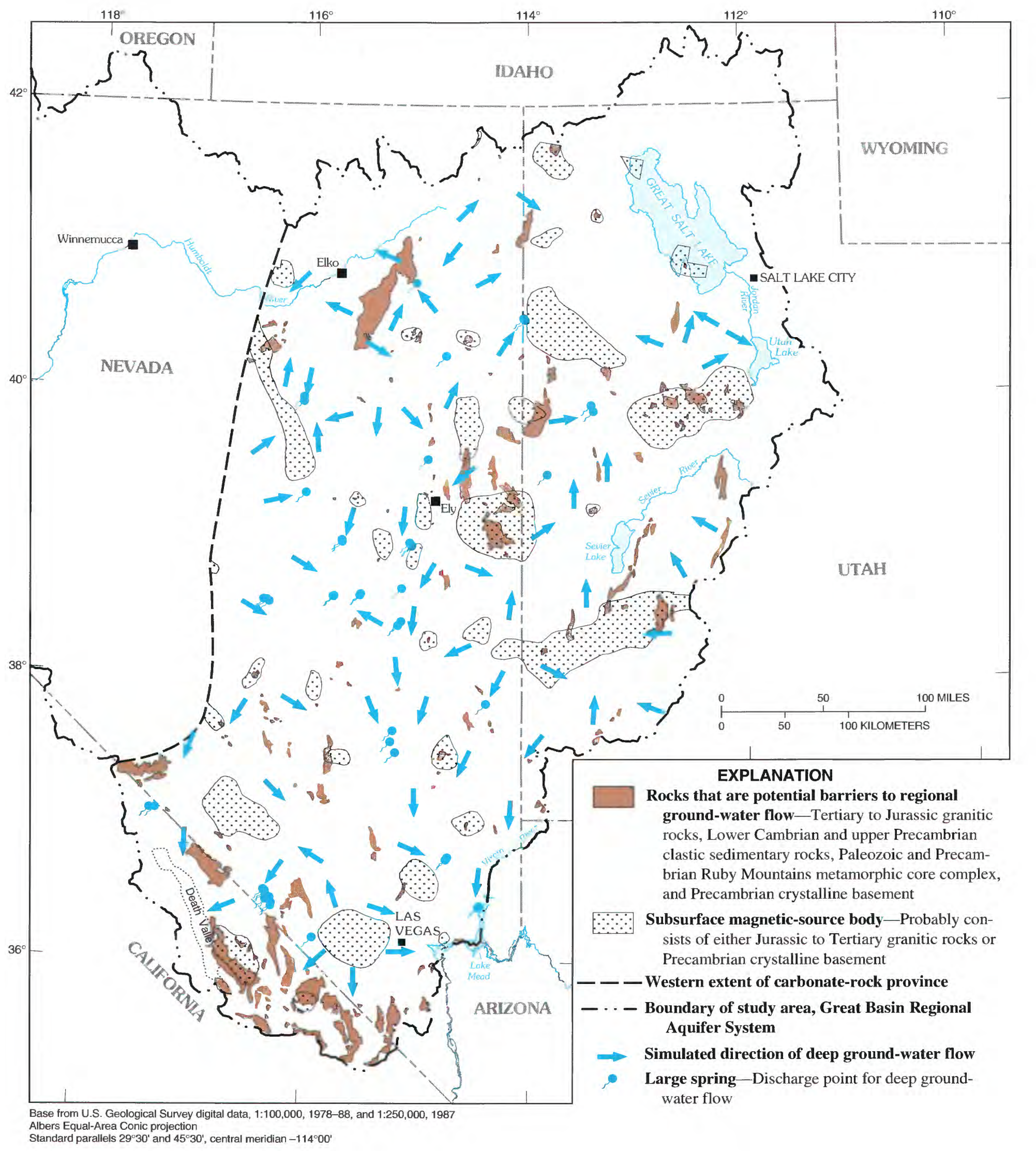

FIGURE 8.-Potential barriers to regional ground-water flow in carbonate-rock province. See figure 1 for geographic setting. Hydrology, geology, and geophysics modified from Prudic and others (1995) and Plume (1996, pl. 5). 


\section{GROUND-WATER RECHARGE}

Aquifers in the Great Basin are recharged from precipitation, mostly winter precipitation that is stored in the form of snowpack in the adjacent mountains. Recharge processes are complex and not fully understood; depending on the characteristics of the rock units that form the mountains, recharge may be either in the mountains or along streams flowing over alluvial deposits adjacent to the mountains. The timing and frequency of recharge also vary widely. The major source areas for ground-water recharge are in the higher parts of the interbasin mountain ranges where precipitation is greater than in the adjacent valleys (fig. 9). Along some reaches of perennial streams, recharge is continuous; in many areas recharge occurs during and after periods of snowmelt or sustained precipitation; and in some areas recharge is infrequent and years may pass before sufficient moisture is accumulated to initiate recharge. Generally, little or no recharge is considered to originate from precipitation that falls on the valley floors. The Great Basin RASA program supported several studies to better understand the recharge process and to develop improved techniques to estimate recharge (Campana and Boone, 1986; Schulke, 1987).

Processes relating to recharge were evaluated by the University of Nevada Desert Research Institute (Campana and Boone, 1986; Schulke, 1987). Study sites were established in northwestern Nevada (in the Clear Creek drainage near Carson City and in the Virginia City Highlands area) and in southern Nevada (in the Kyle Canyon area northwest of Las Vegas). In addition, psychrometers were set up at sites in northwestern Nevada in the Virginia City Highlands area and in Reno and at sites in southern Nevada in the Kyle Canyon area and in Jean. The northwestern Nevada studies demonstrated deep percolation and consequent recharge beneath the snowpack during winter. Moreover, rain-on-snow storms produced additional pulses of inflow that were superimposed on steady deep percolation. How much winter recharge ultimately flowed from the mountains into the basin-fill deposits of the adjacent valleys and how much was discharged locally as base flow to streams and as evapotranspiration in areas of shallow ground water in the mountains could not be evaluated from these studies. Differing time lags between periods of recharge and water-level rises in wells in the Virginia City Highlands were interpreted as evidence of poor continuity between local aquifers and of complex localized flow patterns. In southern Nevada, several methods were used to study recharge in the Spring Mountains in the Kyle Canyon area, which is underlain by carbonate rocks (Schulke,
1987, p. 70-81). All methods indicated that almost all recharge was in the mountains. Soil-moisture studies in the lower, more arid environments of southern Nevada found prolonged conditions of very low soil moisture and upward potential gradients in soil moisture. These findings indicate that such areas receive little or no recharge.

Estimating natural recharge to the desert basins within the RASA study area is difficult. Several techniques have been used with varying degrees of success. The approach most commonly applied in Nevada and Utah was developed by Maxey and Eakin (1949). The Maxey-Eakin method entails estimating the total volumes of precipitation falling between specified altitudes in the mountains within the basin of interest, reducing these volumes to account for evaporative losses, and summing the resulting recharge volumes to arrive at an estimate of the total natural recharge from the mountains (Maxey and Eakin, 1949). Because this technique is empirical, it is desirable to use more physically based techniques that provide independent estimates to compare with the Maxey-Eakin estimates. Dettinger (1989b) used a chloride-balance method to estimate natural ground-water recharge in 16 basins in the RASA study area. This method equates chloride in recharge water and runoff to chloride deposited in mountainous source areas by precipitation and dry fallout. Given estimates of annual precipitation on these source areas and chloride concentrations of bulk precipitation and recharge water, the rate of recharge can be estimated provided that no other major sources of chloride exist, that direct runoff to discharge areas in the basin is small or can otherwise be taken into account in the balance, and that the recharge sources for the basin are correctly delineated. Preliminary applications of the method to 16 basins in Nevada produced results that generally correlate well with the corresponding Maxey-Eakin estimates. The correlation coefficient between the recharge efficiencies implied by each method is 0.88 (Dettinger, 1989b, p. 73).

Various investigators who have used the Maxey-Eakin method in specific basins have had to make subjective decisions in applying the method to specific case studies. These decisions relate mostly to matching precipitation rates to altitude zones; however, some investigators have also made adjustments to recharge coefficients to account for large areas of precipitation substantially in excess of 20 in/yr and to account for variations in surficial geology in areas of precipitation of 8 to $12 \mathrm{in} / \mathrm{yr}$. Consequently, the various estimates were evaluated as a single set to determine the degree of consistency that was maintained between individual estimates. This was done by a technique developed by the Southwest Alluvial Basins RASA program (Anderson and others, 1992, p. B33-B34), which 


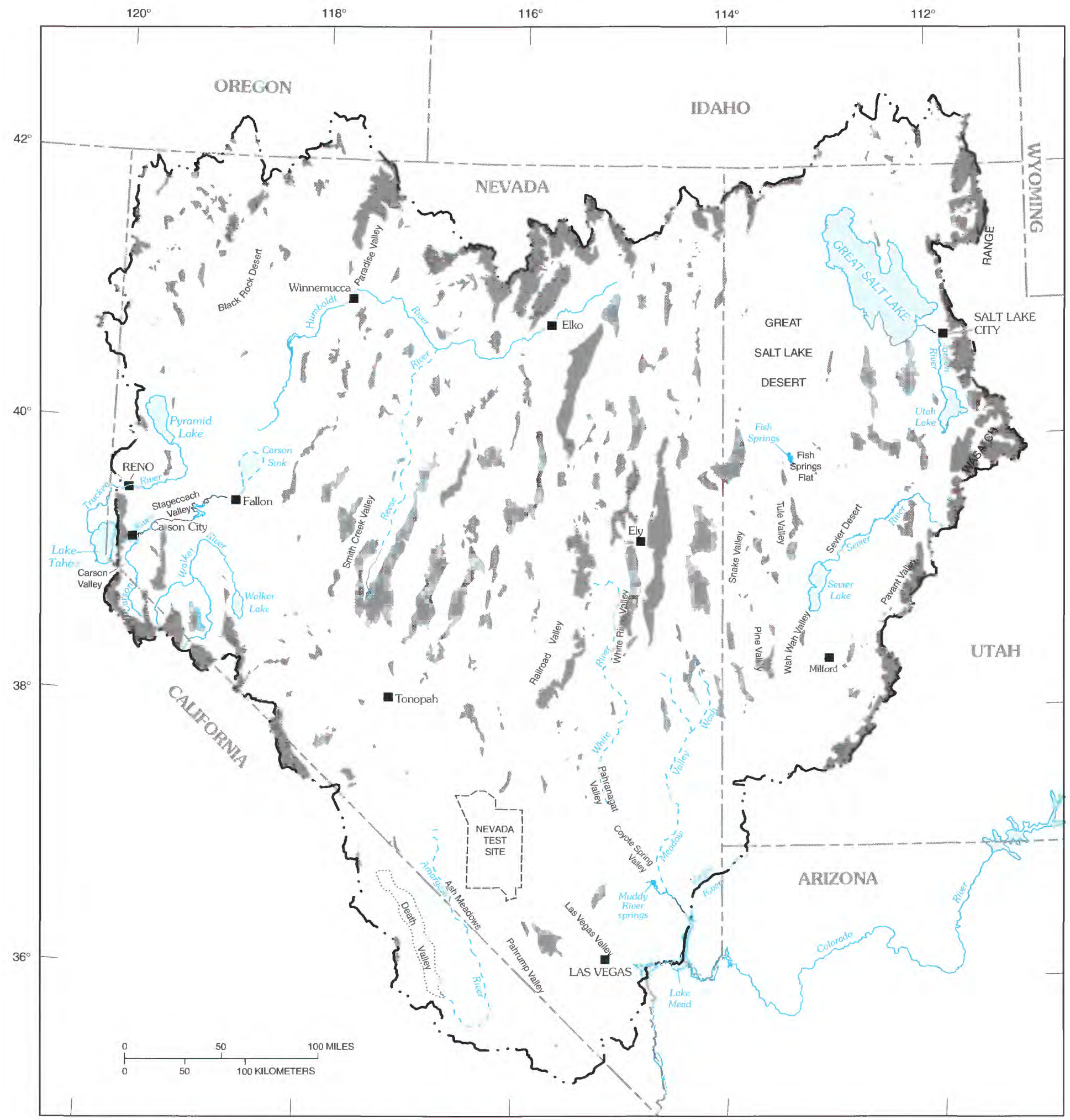

Base from U.S. Geological Survey digital data, 1:100,000, 1978-88, and 1:250,000, 1987 Albers Equal-Area Conic projection

Standard parallels $29^{\circ} 30^{\prime}$ and $45^{\circ} 30^{\prime}$, central meridian $-114^{\circ} 00^{\prime}$

\section{EXPLANATION}

Major source area for ground-water recharge

\section{— - - Boundary of study area, Great Basin Regional Aquifer System}

FIGURE 9.-Major source areas for ground-water recharge. Modified from Mifflin (1988). 
evaluated basin-fill aquifer systems in parts of Arizona and adjacent States. As part of their study, estimates from 12 steady-state flow models were used to develop an empirical relation between mean annual recharge along the mountain front and total volume of annual precipitation on the watershed where annual precipitation exceeds 8 in. Then this relation was extended to all 72 basins in the Southwest Alluvial Basins study area through an iterative process of balancing the individual basin and regional water budgets (Anderson, 1985, p. 102-103). The resulting relation that was developed by Anderson is

$$
\log Q_{\mathrm{r}}=-1.40+0.98 \log P_{P>8},
$$

where $Q_{\mathrm{r}}=$ recharge, in acre-ft/yr; and

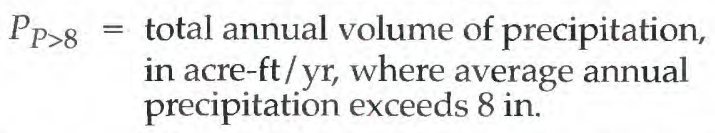

This same general procedure was applied to 167 estimates of recharge in the Great Basin RASA study area (table 3) that were obtained by the Maxey-Eakin method. These estimates were made for basins mostly in Nevada, Utah, and California (fig. 10). The relation between the recharge estimates and estimates of annual precipitation in excess of 8 in. is shown in figure 11. For comparison, Dettinger's (1989b, p. 68-69) 16 recharge estimates obtained by the chloride-balance method are also listed in table 3 (and relevant areas are shown in fig. 10). The resulting equation for the relation between recharge estimated by the Maxey-Eakin method and estimated precipitation volume where annual precipitation exceeds 8 in. is

$$
\log Q_{\mathrm{r}}=-1.74+1.10 \log P_{P>8} .
$$

The various estimates are highly correlated $\left(r^{2}=0.95\right)$. The high correlation indicates that the individual estimates produced by a number of investigators in a number of basins are highly consistent when compared to precipitation and that individual subjective decisions did not impair the overall consistency of the set of estimates. The preceding evaluation does not address the accuracy of the estimates made using this relation; however, the exponential equation developed by the Maxey-Eakin estimates of recharge is similar to the equation for estimates in Arizona that were developed by different techniques. Determining whether the small differences in the two equations could be attributed to differences in precipitation, lithology, altitude, latitude or longitude, or other factors was not possible within the scope of this study. That precipitation estimates used in the Southwest Alluvial Basins RASA were developed from information sources other than those used in the Great Basin RASA may account for the small differences.

\section{GROUND-WATER DISCHARGE}

The Great Basin RASA study area is characterized by internal drainage. Most ground-water discharge is by evapotranspiration, and most spring discharge ultimately is consumed by evapotranspiration. Areas of ground-water discharge typically are in the topographically low parts of valleys where the water table is near the land surface. The principal areas of ground-water discharge and locations of major springs are shown in figure 12. In the carbonate-rock province, much of the discharge from multibasin ground-water flow systems is by springs. This concentration of spring discharge at the terminus of regional ground-water flow systems is characteristic of the carbonate-rock province.

Rates of evapotranspiration for most of the discharge areas shown in figure 12 have been estimated on the basis of field reconnaissance to determine the area and general character of the vegetation and on the basis of lysimeter measurements in several areas. Estimates of groundwater evapotranspiration are not available for every basin in the study area, but if the flow system is considered to be in a general state of dynamic equilibrium, then the total natural ground-water discharge can be considered to be about equal to the recharge, which is about 3,800,000 acre-ft/yr (Harrill and others, 1988).

The need for improved quantitative determinations of evapotranspiration was recognized in the planning phase of the Great Basin RASA study, and some effort was put into addressing this need. Carman $(1985,1989,1993)$ evaluated selected methods for estimating evapotranspiration from areas of phreatophytes under natural conditions. Two sites were selected for field measurements, one in the Carson Desert Hydrographic Area (table 1) and one in Smith Creek Valley. Instruments were set up at the sites, and data were collected during parts of the 1982 and 1983 growing seasons. Using the data collected during the 1983 growing season, Carman (1993) demonstrated the feasibility of making field measurements of evapotranspiration under conditions that exist in the desert areas of the Great Basin and provided preliminary measurements at specific sites. For example, at the site in Smith Creek Valley, where in 1983 about 25 percent of the area was covered by rabbitbrush and depth to the water table was 10 to $15 \mathrm{ft}$, the total evapotranspiration measured by the eddy-correlation method during 1983 was $1.05 \mathrm{ft}$ (Carman, 1993). Total evapotranspiration includes consumption of soil moisture, of precipitation, and of ground water. Ground-water evapotranspiration cannot be measured directly; however, Robinson (1970, p. D29-D30) reported a mean total annual evapotranspiration for rabbitbrush of $1.66 \mathrm{ft}$ for the 1964, 1966, and 1967 growing seasons measured in a lysimeter where depth to 


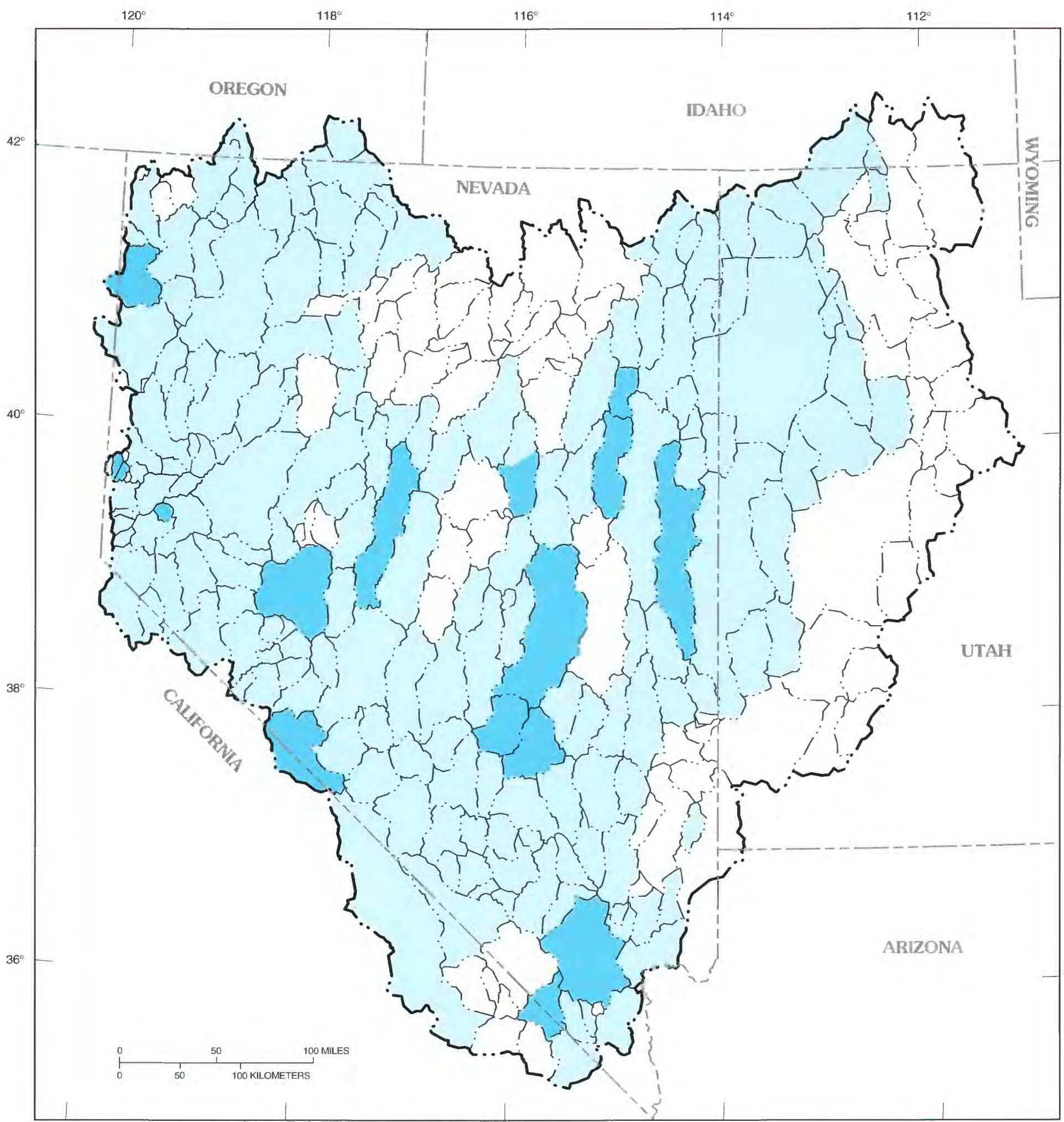

Base from U.S. Geological Survey digital data, 1:100,000, 1978-88, and 1:250,000, 1987 Albers Equal-Area Conic projection

Standard parallels $29^{\circ} 30^{\prime}$ and $45^{\circ} 30^{\prime}$, central meridian $-114^{\circ} 00^{\prime}$

FIGURE 10.-Areas where estimates of recharge (table 3) were used to define relation between recharge and mean annual precipitation in excess of 8 inches (fig. 11). 
the water table ranged from 5 to $6 \mathrm{ft}$. About 64 percent of the total measured evapotranspiration was derived from ground water. If this percentage is representative for Smith Creek Valley, then the estimated consumption of ground water would be about $0.7 \mathrm{ft} / \mathrm{yr}$. Similarly, in the Carson Desert Hydrographic Area, the total evapotranspiration measured by the eddy-correlation method was $1.21 \mathrm{ft}$ in 1983. Depth to water was estimated to be 25 to 30 ft. However, during hand augering, a moist zone was encountered at about $12 \mathrm{ft}$ below land surface. The site was in an area of stabilized dunes with greasewood covering about 5 percent of the area; some shadscale, Great Basin wildrye, and saltcedar were also present, but about 82 percent of the area was bare soil. Robinson (1970, p. D29) reported that the ground-water component of total evapotranspiration by rabbitbrush, measured in a lysimeter, where depth to water ranged from 5 to $7.8 \mathrm{ft}$ during four field seasons, was 50 percent of the total evapotranspiration. If this percentage is representative for the site in the Carson Desert Hydrographic Area, then the estimated rate of ground-water evapotranspiration would be about $0.6 \mathrm{ft} / \mathrm{yr}$.

An alternate method of estimating evapotranspiration rates in Smith Creek Valley was used by Hines (1992). He applied evapotranspiration rates measured in lysimeters by Robinson (1970) to stands of phreatophytic vegetation in Smith Creek Valley. To do this he transferred rates that Robinson had normalized in terms of acre-feet of water consumed per acre-foot of foliage and assumed that the same percentage of the total evapotranspiration as determined by Robinson was supplied by ground water. Native vegetation in Smith Creek Valley was grouped into five zones on the basis of foliage density and plantspecies composition. The estimated ground-water evapotranspiration rate for three stands dominated by greasewood ranged from 0.1 to $0.9 \mathrm{ft} / \mathrm{yr}$, whereas the rate for

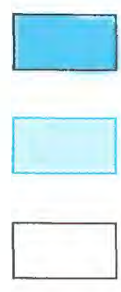

$$
\begin{aligned}
& \text { Recharge } \\
& \text { Estimated by Dettinger's (1989b) chloride- } \\
& \text { balance method } \\
& \text { Estimated by Maxey-Eakin method (Maxey } \\
& \quad \text { and Eakin, 1949) } \\
& \text { Not estimated }
\end{aligned}
$$

Boundary of study area, Great Basin Regional Aquifer System

Boundary of hydrographic area or subarea (fig. 2) stands of pure rabbitbrush was $0.3 \mathrm{ft} / \mathrm{yr}$. Discharge to bare soil in the playa was estimated by using a flow net and Darcy's law. Evaporation rates for bare soil ranged from 0.1 to $0.5 \mathrm{ft} / \mathrm{yr}$ and for the entire main playa averaged about $0.2 \mathrm{ft} / \mathrm{yr}$. The overall estimated volume of evapotranspiration compared well with the existing reconnaissance estimate. However, the rates used by Hines (1992) are slightly higher than some of the average rates used for the reconnaissance study; also, he did more-detailed field evaluation and mapped a slightly smaller area of phreatophytes.

\section{REGIONAL GROUND-WATER FLOW}

\section{CONCEPTS OF REGIONAL FLOW}

To evaluate regional ground-water flow in the Great Basin study area, theoretical aspects of ground-water flow systems were applied to the area. Such theoretical aspects were examined in the 1960's by Tóth $(1962,1963)$ and Freeze and Witherspoon $(1966,1967)$, who modeled hypothetical ground-water flow systems along vertical sections. Tóth (1963, p. 4807) used a system of uniform permeability to demonstrate that, if the potential on the surface of the system differed from a linear gradient, circulation cells would form in response to local areas of recharge and discharge. These recharge and discharge areas correspond to areas of localized high and low potential, respectively. Tóth (1963) was able to identify three types of flow systems-local, intermediate, and regional-on the basis of the length of flow lines and by whether flow passed beneath local or intermediate areas of high or low potential. Tóth's findings that are most applicable to the Great Basin are that (1) deep regional flow can pass beneath shallow local areas of high potential (ground-water divides) and (2) variations in permeability within the system can cause appreciable discharge upgradient from the hydraulic terminus of the system. To evaluate regional ground-water flow in the Great Basin, Prudic and others (1995) represented ground-water flow from recharge areas in the mountains to discharge areas on the basin floors as shown in figure 13. A schematic geohydrologic cross section is shown in figure $13 \mathrm{~A}$. The same concept represented by a finite-difference computer model is depicted in figure $13 B$, in which the shallow-flow and deep-flow regions generally correspond to Tóth's (1963) intermediate and regional flow systems. Local flow systems were ignored in these regional-scale flow patterns. 


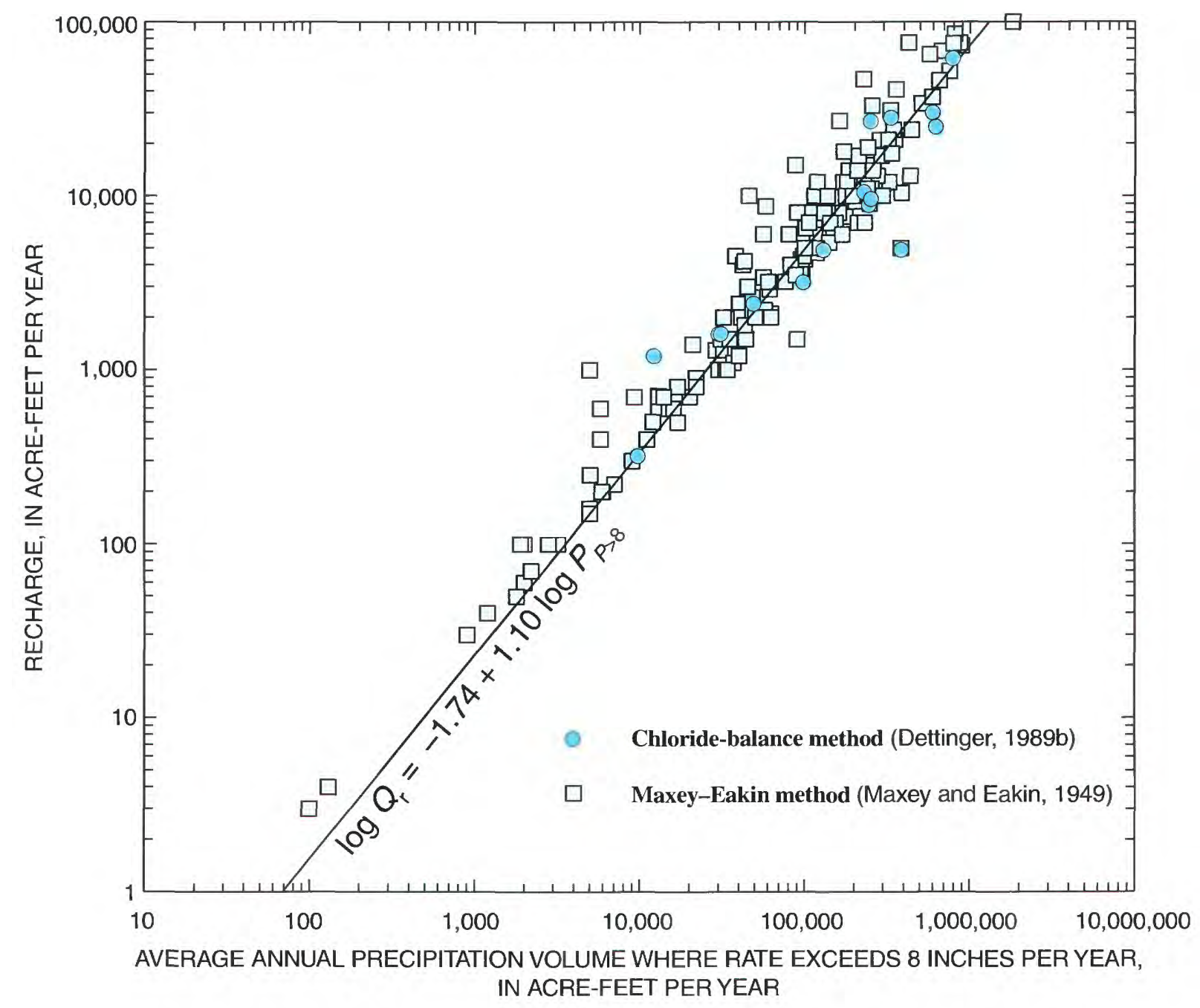

FIGURE 11.- Relation between recharge and mean annual precipitation volume where precipitation rate exceeds 8 inches per year (fig. 10).

\section{POTENTIAL FOR REGIONAL GROUND-WATER FLOW}

Large ground-water flow systems are driven by hydraulic gradients that are continuous over long distances. These large systems generally are the deep-flow regions described in the section "Concepts of Regional Flow." Bredehoeft and others (1982) reviewed the development of concepts relating to regional ground-water flow. One principle they listed as governing regional ground-water flow was that "differences in hydraulic head produced by topographic relief on the boundaries of the system are, in most instances, the driving force for the flow" (Bredehoeft and others, 1982, p. 297). This principle was used to evaluate the potential for regional flow in the Great Basin. The approach taken was to determine the lowest water-level altitude in the basin-fill deposits of each valley, which generally is only slightly below the topographically lowest point in the basin, and then to draw smooth contours through the altitude points for each valley. Regional flow potential obtained by this method is shown in figure 14. If basin-fill deposits and consolidated rocks are sufficiently permeable, regional flow would be toward the Colorado River or major sinks. Thomas and others (1986) developed more detailed information on regional hydraulic gradients, which was used to support simulations discussed in the section "Simulation of Regional Ground-Water Flow in CarbonateRock Province."

\section{DESCRIPTION OF REGIONAL SYSTEMS}

The major flow systems in the Great Basin RASA study area are considered herein to be the local, intermediate, or regional system that is dominant-commonly the one conveying the largest percentage of ground water in a specified area. Where consolidated rocks are permeable 
TABLE 3.-Recharge estimated by Maxey-Eakin and chloride-balance methods for selected areas where annual precipitation exceeds 8 inches in Great Basin study area

[Hydrographic area or subarea: See figure 2 and table 1. Do., ditto]

\begin{tabular}{|c|c|c|c|c|}
\hline \multicolumn{2}{|r|}{ Hydrographic area or subarea } & \multirow{2}{*}{$\begin{array}{l}\text { Precipitation volume } \\
\text { where precipitation rate } \\
\text { exceeds } 8 \text { inches per year } \\
\text { (acre-feet per year) }\end{array}$} & \multirow{2}{*}{$\begin{array}{l}\text { Recharge } \\
\text { (acre-feet } \\
\text { per year) }\end{array}$} & \multirow[b]{2}{*}{ Reference } \\
\hline Number & $\begin{array}{l}\text { Name of area, subarea, } \\
\text { or part of area }\end{array}$ & & & \\
\hline \multicolumn{5}{|c|}{ Maxey-Eakin method } \\
\hline 2 & Continental Lake Valley & 254,000 & 11,000 & Sinclair, 1963d \\
\hline 3 & Gridley Lake Valley & 98,000 & 4,500 & 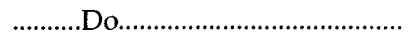 \\
\hline 3 & Massacre Lake Valley & 88,000 & 3,500 & Sinclair, 1963c \\
\hline 4 & Virgin Valley & 230,000 & 7,000 & Sinclair, 1963d \\
\hline 9 & Long Valley & 168,000 & 6,000 & Sinclair, $1963 c$ \\
\hline 12 & Mosquito Valley & 14,000 & 700 & 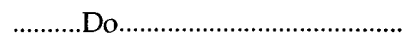 \\
\hline 15 & Boulder Valley & 50,000 & 2,000 & 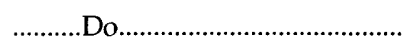 \\
\hline 16 & Duck Lake Valley & 247,000 & 9,000 & Sinclair, $1963 b$ \\
\hline 19 & Dry Valley & 5,900 & 200 & Glancy and Rush, 1968 \\
\hline 20 & Sano Valley & 130 & 4 & 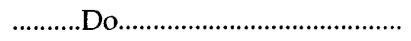 \\
\hline 21 & Smoke Creek Desert & 275,000 & 13,000 & 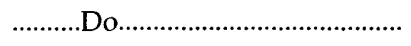 \\
\hline 22 & San Emidio Desert & 48,000 & 2,100 & 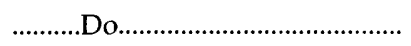 \\
\hline 23 & Granite Basin & 5,800 & 400 & Sinclair, 1963a \\
\hline 24 & Hualapai Flat & 106,000 & 7,000 & Harrill, 1969 \\
\hline 25 & High Rock Lake Valley & 435,000 & 13,000 & Sinclair, 1963a \\
\hline 26 & Mud Meadow & 131,000 & 8,000 & 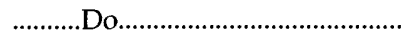 \\
\hline 28 & Black Rock Desert & 258,000 & 14,000 & 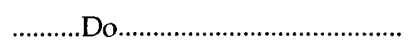 \\
\hline 28 & Summit Lake & 43,000 & 4,200 & 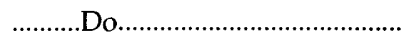 \\
\hline 29 & Pine Forest Valley & 195,000 & 10,000 & Sinclair, $1962 b$ \\
\hline 30 & Kings River Valley & 260,000 & 15,000 & Malmberg and Worts, 1966 \\
\hline 31 & Desert Valley & 100,000 & 5,000 & Sinclair, 1962a \\
\hline 32 & Silver State Valley & 35,000 & 1,400 & Huxel and others, 1966 \\
\hline 33 & Quinn River Valley & 890,000 & 73,000 & 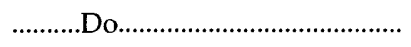 \\
\hline 53 & Pine Valley & 655,000 & 46,000 & Eakin, $1961 b$ \\
\hline 55 & Carico Lake Valley & 95,000 & 4,300 & Everett and Rush, 1966 \\
\hline 56 & Upper Reese River Valley & 591,500 & 37,000 & Eakin and others, 1964 \\
\hline 57 & Antelope Valley & 240,000 & 11,000 & Crosthwaite, 1963 \\
\hline 58 & Middle Reese River Valley & 142,000 & 7,000 & ........Do \\
\hline 67 & Little Humboldt Valley & 443,000 & 24,000 & Harrill and Moore, 1970 \\
\hline 68 & Hardscrabble Area & 115,000 & 9,000 & 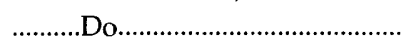 \\
\hline 69 & Paradise Valley & 121,000 & 10,000 & 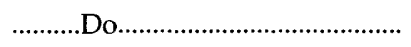 \\
\hline 71 & Grass Valley 1 & 180,000 & 12,000 & Cohen, 1964 \\
\hline 72 & Imlay Area & 82,000 & 4,000 & Eakin, $1962 c$ \\
\hline 73 & Lovelock Valley & 60,000 & 3,200 & Everett and Rush, 1965 \\
\hline 74 & White Plains & 100 & 3 & Glancy and Katzer, 1976 \\
\hline 75 & Bradys Hot Springs Area & 5,000 & 160 & Harrill, 1970 \\
\hline 76 & Fernley Area & 13,000 & 600 & Van Denburgh and others, 1973 \\
\hline 77 & Fireball Valley & 6,000 & 200 & Harrill, 1970 \\
\hline 78 & Granite Springs Valley & 96,000 & 3,500 & 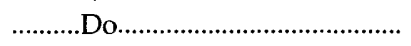 \\
\hline 79 & Kumiva Valley & 30,000 & 1,000 & 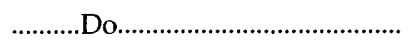 \\
\hline
\end{tabular}


TABLE 3.-Recharge estimated by Maxey-Eakin and chloride-balance methods for selected areas where annual precipitation exceeds 8 inches in Great Basin study area-Continued

\begin{tabular}{|c|c|c|c|c|}
\hline \multicolumn{2}{|r|}{ Hydrographic area or subarea } & \multirow{2}{*}{$\begin{array}{l}\text { Precipitation volume } \\
\text { where precipitation rate } \\
\text { exceeds } 8 \text { inches per year } \\
\text { (acre-feet per year) }\end{array}$} & \multirow{2}{*}{$\begin{array}{l}\text { Recharge } \\
\text { (acre-feet } \\
\text { per year) }\end{array}$} & \multirow[b]{2}{*}{ Reference } \\
\hline Number & $\begin{array}{l}\text { Name of area, subarea, } \\
\text { or part of area }\end{array}$ & & & \\
\hline \multicolumn{5}{|c|}{ Maxey-Eakin method-Continued } \\
\hline 80 & Winnemucca Lake Valley & 61,000 & 2,900 & Van Denburgh and others, 1973 \\
\hline 81 & Pyramid Lake Valley & 103,000 & 6,600 & 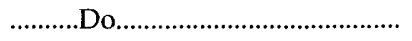 \\
\hline 82 & Dodge Flat & 21,000 & 1,400 & 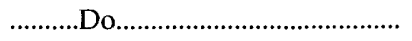 \\
\hline 83 & Tracy Segment & 121,000 & 6,000 & 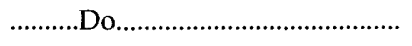 \\
\hline 84 & Warm Springs Valley & 96,000 & 6,000 & Rush and Glancy, 1967 \\
\hline 85 & Spanish Springs Valley & 16,000 & 600 & 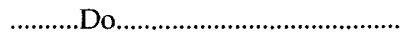 \\
\hline 86 & Sun Valley & 1,800 & 50 & 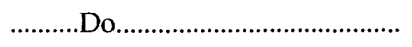 \\
\hline 87 & Truckee Meadows & 161,900 & 27,000 & Van Denburgh and others, 1973 \\
\hline 88 & Pleasant Valley & 46,000 & 10,000 & 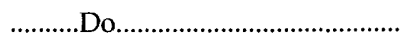 \\
\hline 89 & Washoe Valley & 87,000 & 15,000 & Rush, 1967 \\
\hline 92 & Lemmon Valley & 44,000 & 1,500 & Harrill, 1973 \\
\hline 93 & Antelope Valley & 9,000 & 300 & Rush and Glancy, 1967 \\
\hline $103 \mathrm{~A}$ & Packard Valley & 13,000 & 710 & Glancy and Katzer, 1976 \\
\hline $101 B$ & Lahontan Valley & 29,000 & 1,300 & 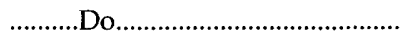 \\
\hline 102 & Churchill Valley & 32,000 & 1,300 & 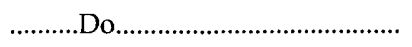 \\
\hline 103 & Dayton Valley & 125,000 & 7,900 & 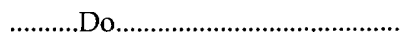 \\
\hline 104 & Eagle Valley & 58,000 & 8,700 & Worts and Malmberg, 1966 \\
\hline 105 & Carson Valley & 357,000 & 41,000 & Glancy and Katzer, 1976 \\
\hline 106 & Antelope Valley & 172,000 & 18,000 & Glancy, 1971 \\
\hline 107 & Smith Valley & 210,000 & 17,000 & Rush and Schroer, 1976 \\
\hline 108 & Mason Valley & 32,000 & 2,000 & Huxel and Harris, 1969 \\
\hline 109 & East Walker Area & 331,000 & 31,000 & Glancy, 1971 \\
\hline 110 & Walker Lake Valley & 101,000 & 6,500 & Everett and Rush, 1967 \\
\hline 113 & Huntoon Valley & 22,000 & 800 & Van Denburgh and Glancy, 1970 \\
\hline 114 & Teels Marsh Valley & 38,000 & 1,300 & Van Denburgh and Glancy, 1970 \\
\hline 117 & Fish Lake Valley & 255,000 & 33,000 & Rush and Katzer, 1973 \\
\hline 118 & Columbus Salt Marsh Valley & 13,000 & 700 & Van Denburgh and Glancy, 1970 \\
\hline 119 & Rhodes Salt Marsh Valley & 12,000 & 500 & 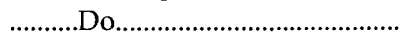 \\
\hline 120 & Garfield Flat & 9,000 & 300 & 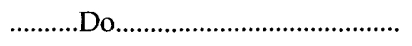 \\
\hline 121 & Soda Spring Valley & 20,000 & 700 & 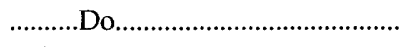 \\
\hline 122 & Gabbs Valley & 383,000 & 5,000 & Eakin, $1962 b$ \\
\hline 123 & Rawhide Flats & 5,000 & 150 & Everett and Rush, 1967 \\
\hline 124 & Fairview Valley & 17,000 & 500 & Cohen and Everett, 1963 \\
\hline 128 & Dixie Valley & 80,000 & 6,000 & 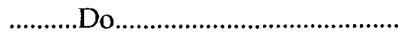 \\
\hline 130 & Pleasant Valley & 45,000 & 3,000 & 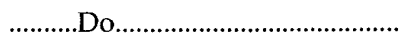 \\
\hline 132 & Jersey Valley & 17,000 & 800 & 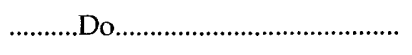 \\
\hline 133 & Edwards Creek Valley & 111,000 & 8,000 & Everett, 1964 \\
\hline 134 & Smith Creek Valley & 119,000 & 12,000 & Everett and Rush, 1964 \\
\hline 135 & Ione Valley & 90,000 & 8,000 & 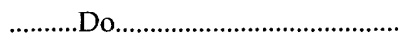 \\
\hline 136 & Monte Cristo Valley & 12,000 & 500 & Van Denburgh and Glancy, 1970 \\
\hline
\end{tabular}


TABLE 3.-Recharge estimated by Maxey-Eakin and chloride-balance methods for selected areas where annual precipitation exceeds 8 inches in Great Basin study area-Continued

[Hydrographic area or subarea: See figure 2 and table 1. Do., ditto]

\begin{tabular}{|c|c|c|c|c|}
\hline \multicolumn{2}{|r|}{ Hydrographic area or subarea } & \multirow{2}{*}{$\begin{array}{c}\text { Precipitation volume } \\
\text { where precipitation rate } \\
\text { exceeds } 8 \text { inches per year } \\
\text { (acre-feet per year) }\end{array}$} & \multirow{2}{*}{$\begin{array}{l}\text { Recharge } \\
\text { (acre-feet } \\
\text { per year) }\end{array}$} & \multirow[b]{2}{*}{ Reference } \\
\hline Number & $\begin{array}{c}\text { Name of area, subarea, } \\
\text { or part of area }\end{array}$ & & & \\
\hline \multicolumn{5}{|c|}{ Maxey-Eakin method-Continued } \\
\hline $137 \mathrm{~A}$ & Tonopah Flat & 171,000 & 12,000 & Rush and Schroer, 1971 \\
\hline $137 \mathrm{~B}$ & Big Smoky Valley (Northern Part) & 570,000 & 65,000 & 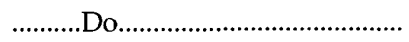 \\
\hline 138 & Grass Valley ${ }^{1}$ & 211,000 & 13,000 & Everett and Rush, 1966 \\
\hline 141 & Ralston Valley & 115,000 & 5,000 & Rush, 1968b \\
\hline 143 & Clayton Valley & 35,000 & 1,500 & 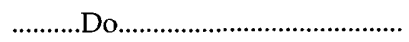 \\
\hline 145 & Stonewall Flat & 1,900 & 100 & 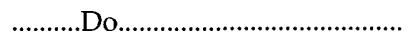 \\
\hline 146 & Sarcobatus Flat & 40,000 & 1,200 & Malmberg and Eakin, 1962 \\
\hline 147 & Gold Flat & 94,000 & 3,800 & Rush, 1971 \\
\hline 148 & Cactus Flat & 15,000 & 600 & 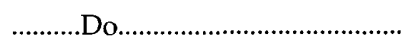 \\
\hline 149 & Stone Cabin Valley & 103,000 & 5,000 & Rush, $1968 b$ \\
\hline 150 & Little Fish Lake Valley & 181,000 & 11,000 & Rush and Everett, 1966 \\
\hline 153 & Diamond Valley & 319,000 & 21,000 & Harrill, 1968 \\
\hline 154 & Newark Valley & 335,000 & 17,500 & Eakin, 1960 \\
\hline 155 & Little Smoky Valley & 140,000 & 5,400 & Rush and Everett, 1966 \\
\hline 156 & Hot Creek Valley & 153,000 & 7,000 & 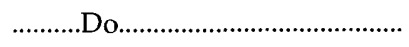 \\
\hline 157 & Kawich Valley & 88,000 & 3,500 & Rush, 1971 \\
\hline $158 \mathrm{~A}$ & Groom Lake Valley & 76,000 & 3,200 & Rush, 1971 \\
\hline 158B & Papoose Lake Valley & 130 & 4 & 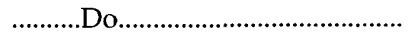 \\
\hline 159 & Yucca Flat & 9,300 & 700 & 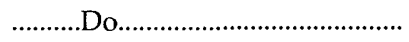 \\
\hline 161 & Indian Springs Valley & 115,000 & 10,000 & 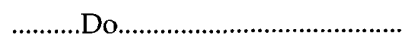 \\
\hline 163 & Mesquite Valley & 31,000 & 1,500 & Glancy, $1968 b$ \\
\hline 164 & Ivanpah Valley & 36,000 & 1,500 & 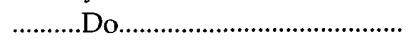 \\
\hline 165 & Jean Lake Valley & 2,000 & 100 & 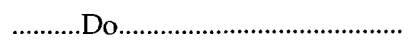 \\
\hline 167 & Eldorado Valley & 37,000 & 1,100 & Rush and Huxel, 1966 \\
\hline 168 & Three Lakes Valley (Northern Part) & 41,000 & 2,000 & Rush, 1971 \\
\hline 169 & Tikapoo Valley & 115,000 & 6,000 & 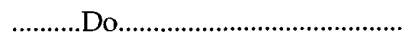 \\
\hline 170 & Penoyer Valley & 100,000 & 4,300 & Van Denburgh and Rush, 1974 \\
\hline 171 & Coal Valley & 62,000 & 2,000 & Eakin, $1963 b$ \\
\hline 172 & Garden Valley & 137,000 & 10,000 & 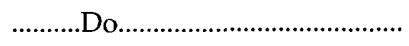 \\
\hline 173 & Railroad Valley & 754,000 & 52,000 & Van Denburgh and Rush, 1974 \\
\hline 175 & Long Valley & 297,000 & 10,000 & Eakin, 1961a \\
\hline 176 & Ruby Valley & 674,000 & 68,000 & Eakin and others, 1951 \\
\hline 177 & Clover Valley & 285,000 & 21,000 & 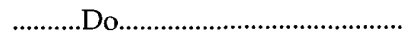 \\
\hline 178 & Butte Valley & 240,000 & 19,000 & Glancy, 1968a \\
\hline 179 & Steptoe Valley & 810,000 & 85,000 & Eakin and others, 1967 \\
\hline 180 & Cave Valley & 207,000 & 14,000 & Eakin, 1962a \\
\hline 181 & Dry Lake Valley & 118,000 & 5,000 & Eakin, $1963 a$ \\
\hline 182 & Delamar Valley & 34,000 & 1,000 & 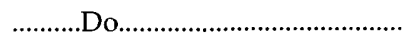 \\
\hline 183 & Lake Valley & 229,000 & 13,000 & Rush and Eakin, 1963 \\
\hline
\end{tabular}


TABLE 3.-Recharge estimated by Maxey-Eakin and chloride-balance methods for selected areas where annual precipitation exceeds 8 inches in Great Basin study area-Continued

[Hydrographic area or subarea: See figure 2 and table 1. Do., ditto]

\begin{tabular}{|c|c|c|c|c|}
\hline \multicolumn{2}{|r|}{ Hydrographic area or subarea } & \multirow{2}{*}{$\begin{array}{l}\text { Precipitation volume } \\
\text { where precipitation rate } \\
\text { exceeds } 8 \text { inches per year } \\
\text { (acre-feet per year) }\end{array}$} & \multirow{2}{*}{$\begin{array}{l}\text { Recharge } \\
\text { (acre-feet } \\
\text { per year) }\end{array}$} & \multirow[b]{2}{*}{ Reference } \\
\hline Number & $\begin{array}{c}\text { Name of area, subarea, } \\
\text { or part of area }\end{array}$ & & & \\
\hline \multicolumn{5}{|c|}{ Maxey-Eakin method-Continued } \\
\hline 184 & Spring Valley & 791,000 & 75,000 & Rush and Kazmi, 1965 \\
\hline 185 & Tippett Valley & 114,000 & 6,900 & Harrill, 1971 \\
\hline 186 & Antelope Valley & 117,000 & 4,700 & 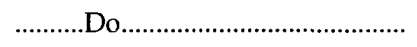 \\
\hline 187 & Goshute Valley & 386,000 & 10,400 & Eakin and others, 1951 \\
\hline 188 & Independence Valley (Pequop Valley) & 203,000 & 9,300 & 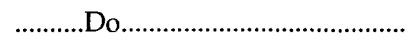 \\
\hline 189 & Thousand Springs Valley & 325,000 & 12,000 & Rush, 1968d \\
\hline 191 & Pilot Creek Valley & 40,000 & 2,400 & Harrill, 1971 \\
\hline 142 & Alkali Spring Valley & 2,800 & 100 & Rush, 1968b \\
\hline 201 & Spring Valley & 177,000 & 10,000 & Rush, 1964 \\
\hline 202 & Patterson Valley & 137,000 & 8,000 & 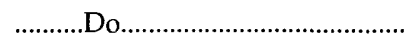 \\
\hline 208 & Pahroc Valley & 57,000 & 2,200 & Eakin, $1963 c$ \\
\hline 209 & Pahranagat Valley & 43,000 & 1,800 & 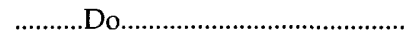 \\
\hline 210 & Coyote Spring Valley & 48,000 & 2,600 & Eakin, 1964 \\
\hline 211 & Three Lakes Valley (Southern Part) & 56,000 & 6,000 & Rush, 1971 \\
\hline 215 & Black Mountains Area & 2,200 & 70 & Rush, $1968 c$ \\
\hline 216 & Garnet Valley & 11,000 & 400 & 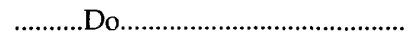 \\
\hline 217 & Hidden Valley (North) & 11,000 & 400 & 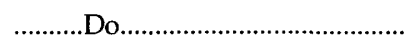 \\
\hline 218 & California Wash & 2,000 & 60 & 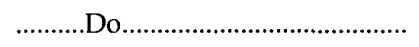 \\
\hline 220 & Lower Moapa Valley & 1,200 & 40 & . Do \\
\hline 221 & Tule Desert & 62,000 & 2,100 & Glancy and Van Denburgh, 1969 \\
\hline 225 & Mercury Valley & 5,000 & 250 & Rush, 1971 \\
\hline 226 & Rock Valley & 900 & 30 & 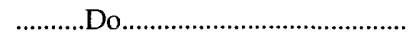 \\
\hline $227 \mathrm{~A}$ & Jackass Flats & 22,000 & 900 & 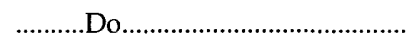 \\
\hline $227 \mathrm{~B}$ & Buckboard Mesa & 39,000 & 1,400 & 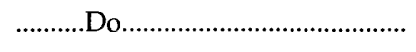 \\
\hline 228 & Oasis Valley & 33,000 & 1,000 & Do \\
\hline 229 & Crater Flat & 7,000 & 220 & 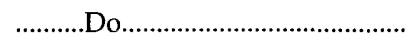 \\
\hline 230 & Amargosa Desert & 90,000 & 1,500 & Walker and Eakin, 1963 \\
\hline 243 & Death Valley & 140,000 & 8,000 & Miller, 1977 \\
\hline 251 & Grouse Creek Valley & 254,000 & 14,000 & Hood and Price, 1970 \\
\hline 252 & Pilot Valley & 56,000 & 3,400 & Stephens and Hood, 1973 \\
\hline 253 & Deep Creek Valley & 290,000 & 17,000 & Hood and Waddell, 1969 \\
\hline 254 & Snake Valley & $1,817,000$ & 100,000 & Hood and Rush, 1965 \\
\hline 255 & Pine Valley & 351,000 & 21,000 & Stephens, 1976 \\
\hline 256 & Wah Wah Valley & 209,000 & 7,000 & Stephens, $1974 b$ \\
\hline 257 & Tule Valley & 176,000 & 7,600 & Stephens, 1977 \\
\hline 258 & Fish Springs Flat & 42,000 & 4,000 & Bolke and Sumsion, 1978 \\
\hline 259 & Dugway-Government Creek Valley & 143,000 & 7,000 & Stephens and Sumsion, 1978 \\
\hline 260 & Park Valley & 344,000 & 24,000 & Hood, 1971b \\
\hline \multirow[t]{2}{*}{261} & Great Salt Lake Desert (southern) & 226,000 & 47,000 & Gates and Kruer, 1981 \\
\hline & Great Salt Lake Desert (northern) & 38,000 & 4,500 & Stephens, 1974a \\
\hline
\end{tabular}


TABLE 3.-Recharge estimated by Maxey-Eakin and chloride-balance methods for selected areas where annual precipitation exceeds 8 inches in Great Basin study area-Continued

[Hydrographic area or subarea: See figure 2 and table 1. Do., ditto]

\begin{tabular}{|c|c|c|c|c|}
\hline \multicolumn{2}{|r|}{ Hydrographic area or subarea } & \multirow{2}{*}{$\begin{array}{c}\text { Precipitation volume } \\
\text { where precipitation rate } \\
\text { exceeds } 8 \text { inches per year } \\
\text { (acre-feet per year) }\end{array}$} & \multirow{2}{*}{$\begin{array}{l}\text { Recharge } \\
\text { (acre-feet } \\
\text { per year) }\end{array}$} & \multirow[b]{2}{*}{ Reference } \\
\hline Number & $\begin{array}{c}\text { Name of area, subarea, } \\
\text { or part of area }\end{array}$ & & & \\
\hline \multicolumn{5}{|c|}{ Maxey-Eakin method-Continued } \\
\hline 263 & Rush Valley & 510,000 & 34,000 & Hood and others, 1969 \\
\hline 269 & West Shore Area & 5,800 & 600 & Price and Bolke, 1976 \\
\hline 276 & Hansel and Northern Rozel Flat & 160,000 & 8,000 & Hood, 1971a \\
\hline 271 & Sink Valley & 5,000 & 1,000 & Price and Bolke, 1976 \\
\hline 275 & Blue Creek Valley & 184,000 & 14,000 & Bolke and Price, 1972 \\
\hline 278 & Curlew Valley & 868,000 & 75,600 & Bolke and Price, 1969 \\
\hline & & 426,000 & 76,000 & Baker, 1974 \\
\hline \multicolumn{5}{|c|}{ Chloride-balance method } \\
\hline 16 & Duck Lake Valley & 243,000 & 8,900 & Dettinger, $1989 \mathrm{~b}$ \\
\hline 36 & Independence Valley² & 251,000 & 9,700 & 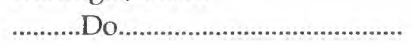 \\
\hline 56 & Upper Reese River Valley & 592,000 & 30,000 & 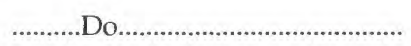 \\
\hline 92 & Lemmon Valley & 30,800 & 1,600 & 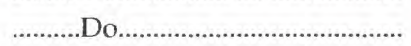 \\
\hline $103 B$ & Stagecoach Valley & 9,700 & 320 & 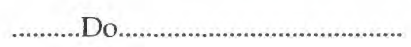 \\
\hline 117 & Fish Lake Valley & 251,000 & 26,800 & 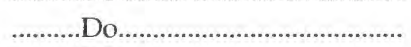 \\
\hline 122 & Gabbs Valley & 381,000 & 4,900 & Do \\
\hline 153 & Diamond Valley & 227,000 & 10,500 & 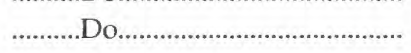 \\
\hline 163 & Mesquite Valley & 30,000 & 1,600 & 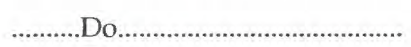 \\
\hline 170 & Penoyer Valley & 97,300 & 3,200 & 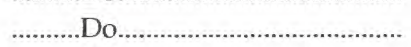 \\
\hline $173 \mathrm{~A}$ & Railroad Valley (Southern Part) & 130,000 & 4,900 & 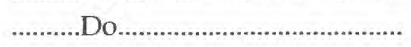 \\
\hline $173 B$ & Railroad Valley (Northern Part) & 616,000 & 24,800 & 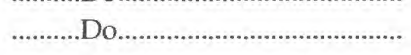 \\
\hline $178 \mathrm{~A}$ & Butte Valley (Northern Part) & 48,700 & 2,400 & 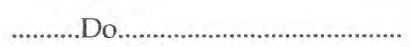 \\
\hline $178 \mathrm{~B}$ & Butte Valley (Southern Part) & 12,200 & 1,200 & Do \\
\hline 184 & Spring Valley & 787,000 & 61,600 & 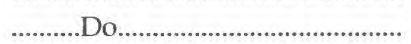 \\
\hline 212 & Las Vegas Valley & 332,500 & 28,000 & 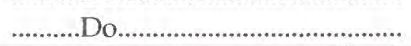 \\
\hline
\end{tabular}

${ }^{1}$ Two areas are called Grass Valley. Area 71 is part of Humboldt flow system; area 138 forms Grass Valley flow system (see table 4 and fig. 15).

${ }^{2}$ Although data from area 36 (Independence Valley) is used in estimating recharge, area is just outside Great Basin study area.

enough to afford significant identifiable hydraulic continuity on a regional scale, the local and intermediate types of systems are considered to be subsystems within regional flow systems. Where consolidated rocks have only low permeability and where water-budget studies do not indicate interbasin flow, regional flow was considered insignificant and the local and intermediate systems were considered to be the major flow systems. Where several basins are traversed by a major stream, and continuity between the basins is provided primarily by the stream, these interconnected basins constitute a complex regional flow system involving substantial interaction between ground water and surface water. The Humboldt River, Truckee River, Carson River, and Walker River Basins of Nevada are examples of this type of system. A basic premise is that each flow system terminates in a dis- charge area. Consequently, if all terminal discharge areas are identified, the task of delineating a flow system is reduced to identifying those areas that contribute flow toward a specified discharge area. For local systems consisting of only one basin or of a discharge area and one or more tributary basins, the task is simple, providing adequate hydrologic data are available. However, some larger regional systems extend for more than $100 \mathrm{mi}$ and have flow paths that traverse as many as seven basins. In most such systems, some water discharges at intermediate points along a regional-flow path from intervening local or intermediate flow systems; consequently, only some of the water flows all the way to the regional discharge area. Boundaries between systems are defined only generally; some are physical barriers to flow, such as masses of intrusive rocks, and others represent ground- 


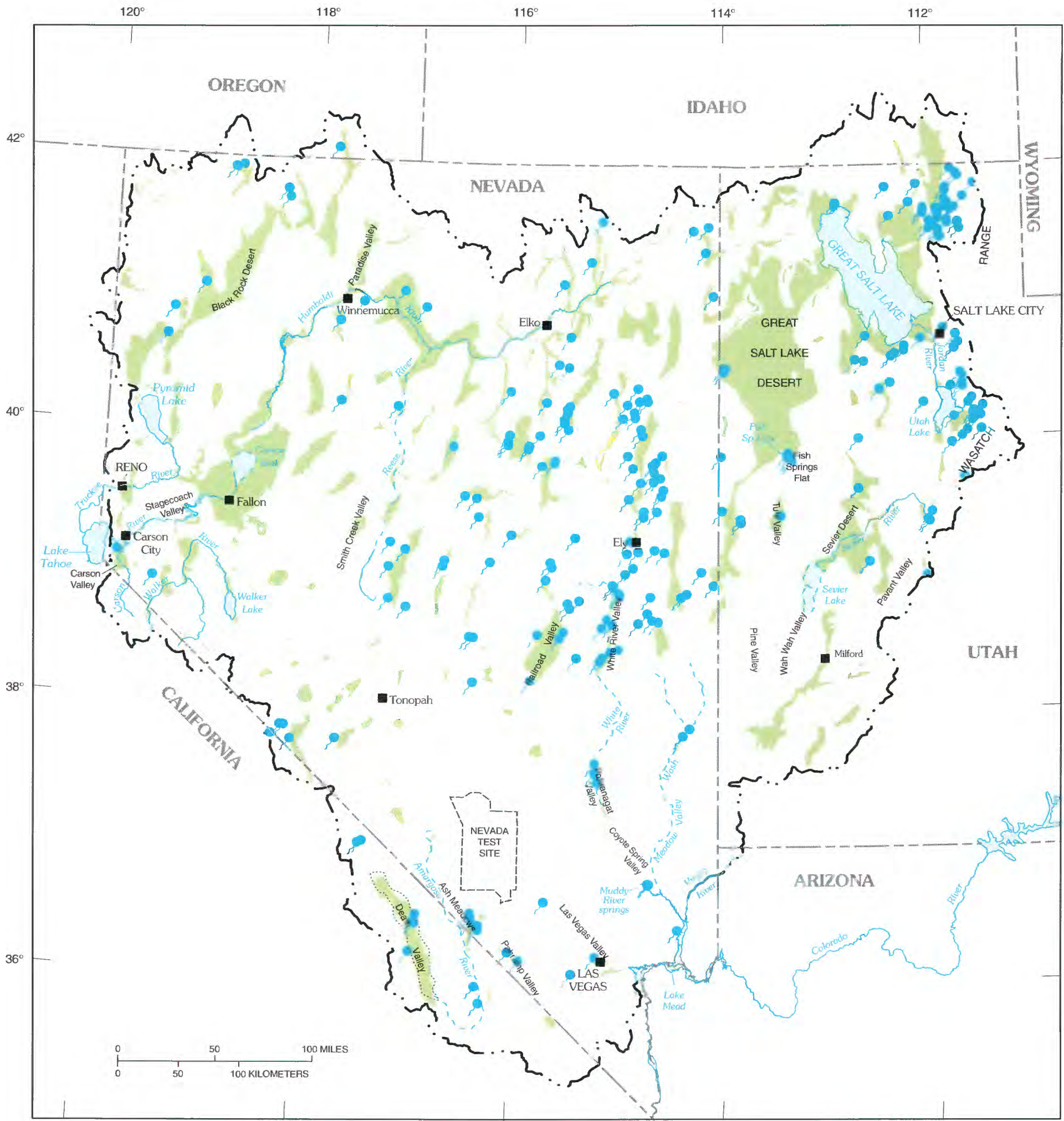

Base from U.S. Geological Survey digital data. 1:100,000, 1978-88, and 1:250,000, 1987 Albers Equal-Area Conic projection

Standard parallels $29^{\circ} 30^{\prime}$ and $45^{\circ} 30^{\prime}$, central meridian $-114^{\circ} 00^{\prime}$

FIGURE 12.-Locations of large springs and areas of ground-water discharge by evapotranspiration. Modified from Harrill and others (1988). 
water divides or areas where flow paths are parallel but ultimately diverge downgradient. For much of the Great Basin, adequate data to precisely define flow-system boundaries currently are not available.

The 39 major flow systems (fig. 15; Harrill and others, 1988) were delineated by applying the general procedures outlined in the section "Regional Ground-Water Flow" to data collected mostly in the shallower parts of the systems. Consequently, the boundaries of the deeper parts of the major flow systems are based primarily on information from the shallow parts of the systems. Recharge and storage data for the 39 flow systems are summarized in table 4.

The 39 major flow systems range in area from 30 to $18,000 \mathrm{mi}^{2}$ (table 4). Of the 39 flow systems, 16 are singlebasin local systems and 23 are multibasin intermediate or regional systems, some of which include as many as 34 hydrographic areas or subareas. Large multibasin flow systems outside the carbonate-rock province are generally coincident with major river systems. Large multibasin systems within the carbonate-rock province typically do not have much surface flow; instead, they may contain ground-water flow paths more than $100 \mathrm{mi}$ long that traverse several basins. Discharge from these systems is typically from large springs. This discharge generally is consumed by evapotranspiration in the vicinity of a spring. Altitudes of terminal discharge areas range from about 5,800 ft in high parts of central Nevada to about 200 $\mathrm{ft}$ below sea level in Death Valley, Calif.

An alternate classification of flow systems in Utah is possible. The Sevier Lake, Great Salt Lake Desert, and Great Salt Lake systems could have been grouped into a large system with its terminus at the Great Salt Lake. Some geologic and hydrologic evidence supports regional continuity between these areas, but significant hydraulic gradients between the areas are virtually nonexistent; consequently, the volume of subsurface flow is relatively small. Moreover, each of the three areas has a distinctive hydrologic character. Therefore this part of the region is described as three major flow systems with three terminal discharge areas.

\section{EXPLANATION}

Area of shallow ground-water discharge by evapotranspiration

Boundary of study area, Great Basin Regional Aquifer System

Large spring - In Utah and most of Nevada, springs having discharge generally greater than 1,000 gallons per minute; in more-arid parts of Nevada, Oregon, and California, regionally significant springs having discharges greater than 200 gallons per minute
In southern Nevada, the hydrologic character of parts of the west boundary of the Colorado system (Harrill and others, 1988) is not well understood and its location is uncertain.

\section{SIMULATION OF GROUND-WATER FLOW}

Simulation results were used in the evaluations and analyses of ground-water flow systems in the Great Basin. Model simulations include a conceptual evaluation of regional ground-water flow in the carbonate-rock province in the eastern Great Basin (hereafter referred to as the carbonate-rock province model), an evaluation of regional ground-water flow in the Fish Springs flow system in western Utah, and detailed evaluations and analyses of selected basin-fill aquifers in five hydrographic areas (fig. 16) in Utah (the Milford area) and in Nevada (Carson, Paradise, Smith Creek, and Stagecoach Valleys). Evaluations and analyses are based on simulations using McDonald and Harbaugh's (1988) finite-difference ground-water flow model.

The following sections describe the simulation of regional ground-water flow in the carbonate-rock province and discuss the results; compare those results, as they apply to the Fish Springs flow system, with findings of the more detailed, independent simulation of regional flow in that system; and describe and compare simulation results for five basin-fill aquifers in Utah and Nevada.

\section{SIMULATION OF REGIONAL GROUND-WATER FLOW IN CARBONATE-ROCK PROVINCE}

A three-dimensional ground-water flow model was used to simulate the concept of shallow ground-water flow systems superimposed on deeper flow systems and to evaluate regional ground-water flow in the carbonaterock province, a $100,000-\mathrm{mi}^{2}$ area that is mostly in eastern Nevada and western Utah (figs. 5 and 16). Detailed analyses of the model results were presented by Prudic and others (1995), and only a summary of the major findings is presented herein. The modeled area is divided into rectangular cells that represent areas $5 \mathrm{mi}$ wide and $7.5 \mathrm{mi}$ long, elongated in a north-northeastward direction. Two model layers are used to simulate the shallow- and deepflow systems; the shallow system is equivalent to Tóth's (1962) intermediate system. The concept of regional-scale ground-water flow and its representation in the threedimensional model are shown in figure 13.

The ground-water flow model of the carbonate-rock province is highly generalized because of the complex geology, scarcity of water-level data, uncertainty in the thickness and extent of aquifers, and uncertainty in estimates of ground-water recharge and evapotranspiration. 

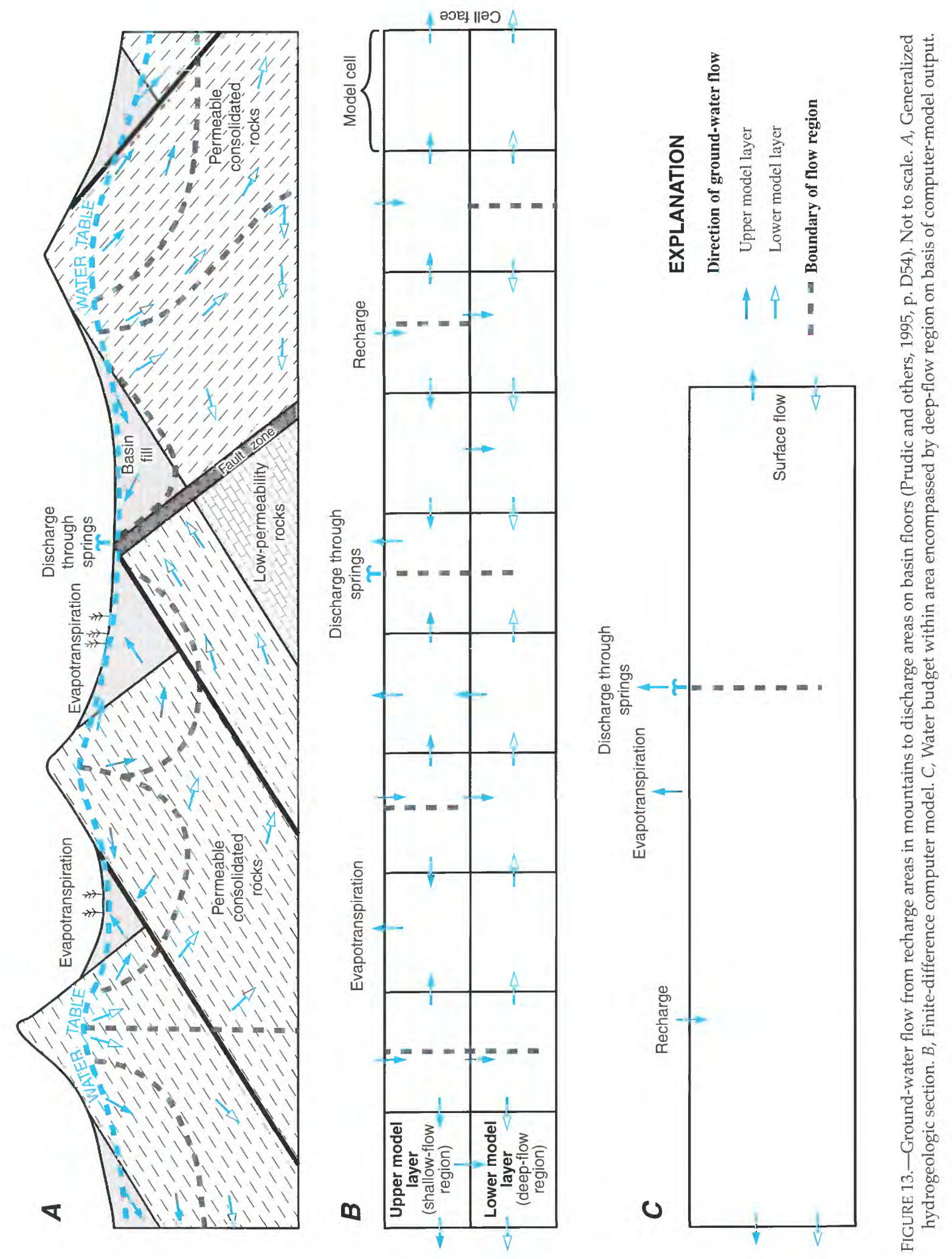
By necessity, several simplifying assumptions are used in the conceptualization and simulation of regional groundwater flow (Prudic and others, 1995, p. D94). The assumptions are important in understanding the limitations of the model results and are summarized as follows: (1) Consolidated rock having abundant fractures and solution openings can be represented on a regional scale as a porous medium. (2) Darcy's law is applicable on a regional scale to flow through the fractures and solution openings and across abrupt changes in lithology. (3) Steady-state conditions prevail: Estimated recharge equals estimated discharge prior to any ground-water development. (Therefore, pumping is not included in the simulation.) (4) Horizontal transmissivity is heterogeneous on a regional scale but is considered to be homogeneous and isotropic within each model cell. (5) Recharge is from precipitation in the mountains and is simulated as a constant rate to model cells in the upper layer. (6) Rivers and lakes that border the modeled area, as well as the Death Valley playa, can be either a source or a sink for ground-water flow. (7) Discharge from regional springs is known, and flow to these springs is through carbonate rocks in the deep-flow system or lower model layer (fig. 13). (8) Spring flow not simulated as discharging from the deep-flow system is included as part of the discharge from shallow ground water, which is simulated as evapotranspiration from the upper model layer.

The validity of each assumption for the entire model is unknown, although each is probably valid for parts of the modeled area. Because of the uncertainty of these assumptions and because the extent, thickness, and hydraulic properties of the aquifers in the region are largely unknown, simulation results do not perfectly replicate ground-water flow. The results do, however, provide a simplified concept of recharge, discharge, and flow in the eastern Great Basin within the limitations of current understanding and the limitations of the model simulations.

The model was calibrated by adjustment of transmissivity and vertical hydraulic conductivity to match observed water levels, areas of evapotranspiration, and discharges from regional springs. Generally, transmissivities in the upper model layer are greater in cells corresponding to basin fill and carbonate rocks and are less in cells corresponding to clastic sedimentary, metamorphic, and igneous rocks. Transmissivities in the lower model layer (fig. 17) are greatest near regional springs and in the vicinity of basins where ground-water discharge is considerably more than the estimated recharge from the immediately surrounding drainage area. In the lower model layer, high transmissivities (values exceeding 0.006 $\mathrm{ft}^{2} / \mathrm{s}$; Prudic and others, 1995, p. D49) may reflect areas where carbonate rocks are thick and generally continuous. High transmissivities extending from east-central
Nevada into southern Nevada correspond to such an area (Dettinger, 1989a, p. 13-16). Similarly, high transmissivities in west-central Utah correspond to an area where carbonate rocks are continuous and relatively thick (Carlton, 1985, p. 11). This area is simulated as a major conduit for northward flow from western Utah into the southern part of the Great Salt Lake Desert.

The model simulates the concept of numerous shallowflow regions superimposed on fewer deep-flow regions. In the upper model layer, 45 shallow-flow regions are distinguished on the basis of horizontal flow between cells (Prudic and others, 1995, p. D53). In the lower layer, flow is grouped into 17 deep-flow subregions, also on the basis of horizontal flow between cells (fig. 18). Because boundaries of the deep-flow subregions do not everywhere correspond to shallow-flow regions, shallow flow moves across underlying deep-flow boundaries at some places and shallow flow moves in a different direction from that of deep flow. Dinwiddie and Schroder (1971) reported different directions of shallow and deeper flow in central Nevada on the basis of water-level data.

Although the number of deep-flow subregions is the same as the number of flow systems delineated by Harrill and others (1988, pl. 2) for the area represented by the model, few of the boundaries between subregions correspond to those of the flow systems (fig. 15). Flow-system boundaries are drawn along topographic divides between basins and are based on water-level gradients and estimated flow budgets in each basin. In contrast, the deep-flow subregion boundaries are based on the area within the lower model layer that contributes horizontal flow to model cells having inward flow. Major differences are apparent in western Utah, where the northern half of the Sevier Lake flow system (number 39 in fig. 15) is part of a deep-flow subregion that includes the Great Salt Lake Desert and the Great Salt Lake, and in southern Nevada, where the Colorado River flow system (number 34 in fig. 15 ) is divided into three deep-flow subregions. These three deep-flow subregions would have been combined as one if the Colorado and Virgin Rivers had been considered to be one discharge area.

The deep-flow subregions are further grouped into five deep-flow regions on the basis of areas having simulated water levels that generally decline toward one of five regional discharge areas. These are named the Death Valley, Colorado River, Bonneville, Railroad Valley, and upper Humboldt River regions (fig. 18). The Bonneville region is the largest and includes about $39,000 \mathrm{mi}^{2}$ in western Utah and eastern Nevada, or about 42 percent of the total modeled area. The Railroad Valley and upper Humboldt River regions are the smallest; each includes about $7,200 \mathrm{mi}^{2}$ or about 8 percent of the modeled area. 


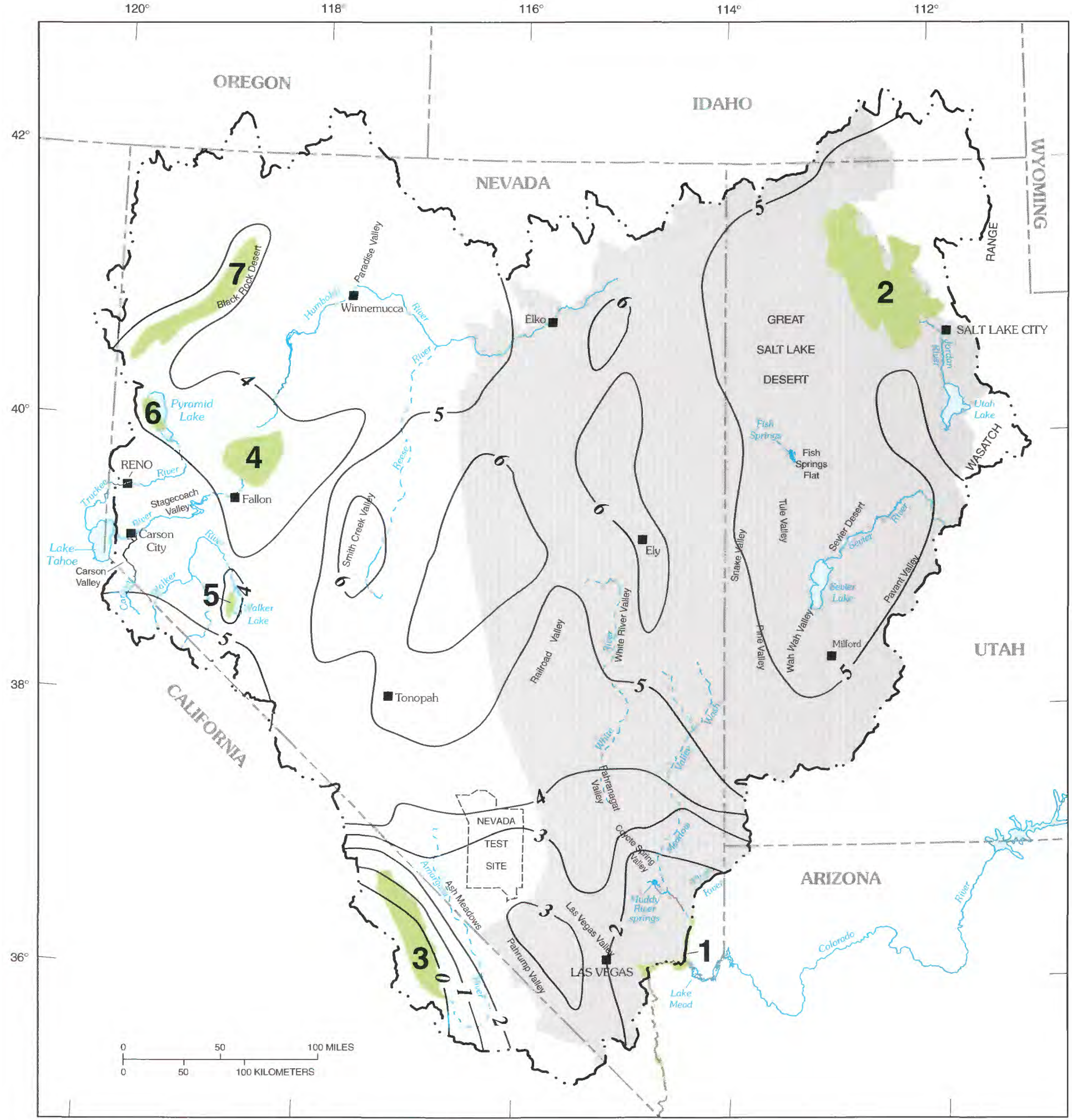

Base from U.S. Geological Survey digital data, 1:100,000, 1978-88, and 1:250,000, 1987 Albers Equal-Area Conic projection

Standard parallels $29^{\circ} 30^{\prime}$ and $45^{\circ} 30^{\prime}$, central meridian $-114^{\circ} 00^{\prime}$ 
Water budgets for each of the deep-flow regions are summarized in table 5. The listed rates of recharge and discharge are assumed to represent long-term steady-state, predevelopment conditions.

The total simulated inflow to the modeled area is about 1.5 million acre-ft/ yr, which corresponds to only 3 percent of the estimated precipitation. About 56 percent of this inflow is in the Bonneville region, where precipitation in the mountains is generally greater than elsewhere in the province. The total simulated inflow does not include recharge that is discharged locally within the $37.5-\mathrm{mi}^{2}$ area represented by each model cell. Most ground-water flow is simulated as shallow flow in the upper model layer. Flow is generally from recharge areas in the mountains to adjacent valley lowlands, where it is discharged by evapotranspiration, which accounts for 79 percent of the simulated discharge from the RASA study area.

In the lower model layer, simulated flow is 428,000 acre$\mathrm{ft} / \mathrm{yr}$, or only 28 percent of the total inflow. About half of this flow is discharged to regional springs as deep flow through carbonate rocks. Much of the discharge to regional springs is in the Colorado River region, which accounts for nearly 46 percent of all regional-spring discharge in the simulation. In this region, simulated discharge to regional springs exceeds evapotranspiration (table 5). This contrasts with the upper Humboldt River region, where regional-spring discharge is only 3 percent of the simulated evapotranspiration.

\section{EXPLANATION}

\section{Carbonate-rock province}

$$
\begin{aligned}
& \text { Regional-discharge area } \\
& 1 \text { Colorado River } \\
& 2 \text { Great Salt Lake } \\
& 3 \text { Death Valley } \\
& 4 \text { Carson Sink } \\
& 5 \text { Walker Lake } \\
& 6 \text { Pyramid Lake } \\
& 7 \text { Black Rock Desert }
\end{aligned}
$$

- 3 - Line of equal regional-flow potential-Number is altitude, in thousands of feet

Boundary of study area, Great Basin Regional Aquifer System
Simulated flow in the lower model layer (deep-flow system) is generally southward and northward from a large, topographic high in east-central Nevada and southwestern Utah. Southward flow is toward Death Valley and the Colorado and Virgin Rivers; northward flow is toward the Great Salt Lake Desert and the upper Humboldt River. Within the topographically high area of eastcentral Nevada, some deep ground water flows to a landsurface depression in Railroad Valley.

The model is a simplification of flow through a geologically complex region, in which hydraulic properties can change abruptly because of changes in lithology and geologic structure. The sparseness of information on the extent of aquifers, their hydraulic properties, and the distribution of water levels precludes developing a model in which only one distribution of transmissivity is possible. Nevertheless, several general statements can be made from the available information and model simulations:

- Most ground-water flow is relatively shallow and moves from recharge areas in the mountain ranges to discharge areas in adjacent valleys.

- Interbasin movement of ground water to the larger regional springs is through permeable carbonate rock in areas where the rock is thick and continuous.

- Where carbonate rock is not thick and continuous, consolidated rock beneath the valleys and surrounding mountains is not highly transmissive. Thus, apparently not all carbonate rock is highly permeable nor are all valleys and surrounding mountains underlain by carbonate rock.

- Carbonate rock may be highly transmissive in some areas, but the rock is separated from overlying aquifers by poorly permeable consolidated rocks and semiconsolidated deposits.

- Only small quantities of deep flow discharge at terminal sinks of the Great Salt Lake, the Great Salt Lake Desert, the Railroad Valley and Death Valley playas, and the Colorado and Virgin Rivers. Instead, deep flow discharges to regional springs and areas of evapotranspiration upgradient from the sinks.

- Only small quantities of deep flow are simulated in the upper Humboldt River region because most of the ground water discharging along the river is from local flow associated with the river. 


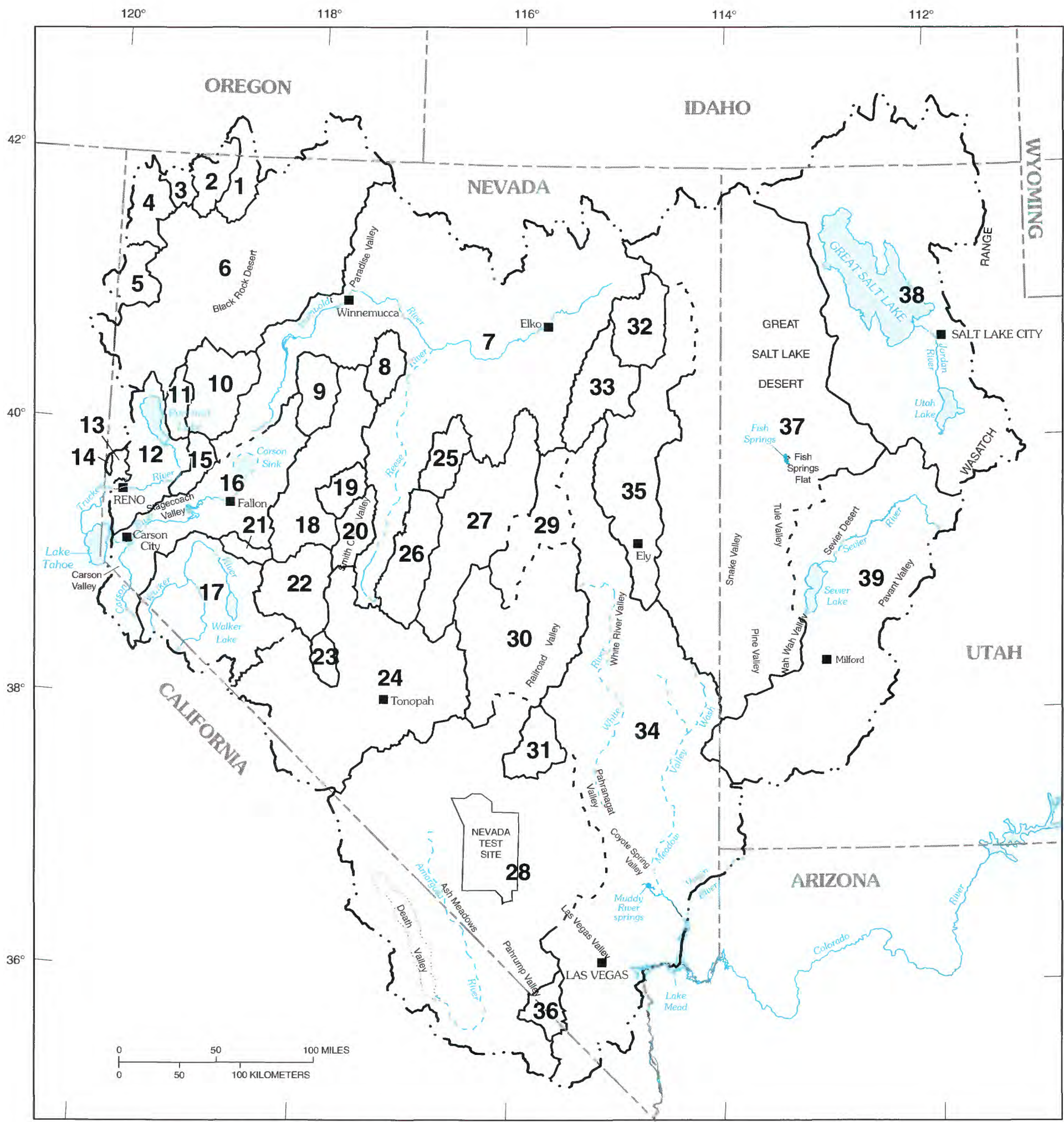

Base from U.S. Geological Survey digital data, 1:100,000, 1978-88, and 1:250,000, 1987

\section{EXPLANATION}

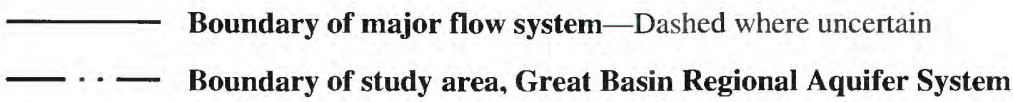

FIGURE 15.-Major ground-water flow systems (cross-referenced by number in table 4) 
TABLE 4.- Selected characteristics of major ground-water flow systems in Great Basin study area

\begin{tabular}{|c|c|c|c|c|c|}
\hline \multicolumn{2}{|c|}{ Major ground-water flow system } & \multirow{2}{*}{$\begin{array}{c}\text { Area } \\
\text { (square miles) }\end{array}$} & \multirow{2}{*}{$\begin{array}{l}\text { Total number } \\
\text { of included } \\
\text { hydrographic } \\
\text { areas or subareas }\end{array}$} & \multirow{2}{*}{$\begin{array}{l}\text { Ground-water } \\
\text { recharge } \\
\text { (acre-feet } \\
\text { per year) }\end{array}$} & \multirow{2}{*}{$\begin{array}{l}\text { Ground-water } \\
\text { storage } \\
\text { (acre-feet } \\
\text { per foot) }\end{array}$} \\
\hline Number & Name & & & & \\
\hline 1 & Continental Lake system & 400 & 2 & 16,000 & 6,100 \\
\hline 2 & Virgin Valley & 494 & 1 & 7,000 & 420 \\
\hline 3 & Swan Lake Valley & 226 & 1 & 6,700 & - \\
\hline 4 & Long Valley system & 729 & 4 & 12,000 & 12,000 \\
\hline 5 & Duck Lake Valley & 533 & 1 & 9,000 & 5,600 \\
\hline 6 & Black Rock Desert system & 9,100 & 18 & 170,000 & 230,000 \\
\hline 7 & Humboldt system & 16,800 & 34 & 500,000 & 330,000 \\
\hline 8 & Buffalo Valley & 504 & 1 & 12,000 & 17,000 \\
\hline 9 & Buena Vista Valley & 742 & 1 & 10,000 & 24,000 \\
\hline 10 & Granite Springs system & 1,300 & 2 & 4,500 & 36,000 \\
\hline 11 & Winnemucca Lake Valley & 371 & 1 & 2,900 & 9,600 \\
\hline 12 & Truckee system & 1,700 & 9 & 73,000 & 36,000 \\
\hline 13 & Lemmon Valley & 111 & 3 & 1,800 & 4,100 \\
\hline 14 & Cold Spring Valley & 30 & 1 & 900 & 450 \\
\hline 15 & Fernley Sink system & 356 & 3 & 960 & 9,000 \\
\hline 16 & Carson system & 3,520 & 7 & 45,000 & 110,000 \\
\hline 17 & Walker system & 3,220 & 9 & 47,000 & 78,000 \\
\hline 18 & Dixie Valley system & 2,380 & 7 & 15,000 & 56,000 \\
\hline 19 & Edwards Creek Valley & 416 & 1 & 8,000 & 7,000 \\
\hline 20 & Smith Creek Valley & 582 & 1 & 12,000 & 15,000 \\
\hline 21 & Rawhide Flats & 227 & 1 & 150 & 600 \\
\hline 22 & Gabbs Valley & 1,280 & 1 & 5,000 & 16,000 \\
\hline 23 & Monte Cristo Valley & 284 & 1 & 500 & 7,200 \\
\hline 24 & South-Central Marshes & 6,790 & 13 & 65,000 & 190,000 \\
\hline 25 & Grass Valley & 595 & 1 & 12,000 & 16,000 \\
\hline 26 & Northern Big Smoky Valley & 1,320 & 1 & 65,000 & 50,000 \\
\hline 27 & Diamond Valley system & 3,120 & 6 & 58,000 & 88,000 \\
\hline 28 & Death Valley system & 15,800 & 30 & 98,000 & 380,000 \\
\hline 29 & Newark Valley system & 1,450 & 3 & 22,000 & 17,000 \\
\hline 30 & Railroad Valley system & 4,130 & 4 & 65,000 & 92,000 \\
\hline 31 & Penoyer Valley & 700 & 1 & 4,300 & 22,000 \\
\hline 32 & Independence Valley system & 1,030 & 2 & 30,000 & 33,000 \\
\hline 33 & Ruby Valley system & 1,280 & 2 & 72,000 & 43,000 \\
\hline 34 & Colorado system & 16,300 & 35 & 200,000 & 440,000 \\
\hline 35 & Goshute Valley system & 3,640 & 3 & 110,000 & 94,000 \\
\hline 36 & Mesquite Valley & 236 & 1 & 1,400 & 7,000 \\
\hline 37 & Great Salt Lake Desert system & 18,000 & 20 & 370,000 & 430,000 \\
\hline 38 & Great Salt Lake system & 12,900 & 22 & $1,380,000$ & 310,000 \\
\hline 39 & Sevier Lake system & 9,100 & 8 & 310,000 & 310,000 \\
\hline \multicolumn{2}{|c|}{ Totals } & 140,000 & 262 & $3,800,000$ & $3,500,000$ \\
\hline
\end{tabular}




\section{FISH SPRINGS FLOW SYSTEM}

Interbasin ground-water flow to Fish Springs in western Utah was analyzed using a three-dimensional ground-water flow model (Carlton, 1985). At Fish Springs, located at the south end of the Great Salt Lake Desert in western Utah (fig. 16), ground water discharges from carbonate-rock aquifers. Discharge at these springs is about 27,000 acre-ft/ yr (Bolke and Sumsion, 1978, p. 10) and greatly exceeds the estimated recharge in the nearby mountains. Gates and Kruer (1981) reported recharge in excess of local discharge in basins to the west and south of the springs, including Tule, Wah Wah, Pine, and Snake Valleys. Simulation of predevelopment steady-state ground-water flow in this region was selected herein for comparison with the results from the simulation of regional ground-water flow in the carbonate-rock province.

The ground-water model of the Fish Springs flow system represents an area of $7,600 \mathrm{mi}^{2}$. The model is divided into a grid of cells each of which represents an area $3 \mathrm{mi}$ by $3 \mathrm{mi}$ (about one-quarter the cell size used in the carbonate-rock province model). The grid is oriented in a north-south direction (fig. 16), about 10 azimuth degrees different from the grid orientation of the carbonate-rock province model. One model layer simulates shallow flow through basin fill in the valleys and consolidated rock in the mountains, and a second model layer simulates deep flow through consolidated rock beneath the valleys and mountains. Consolidated rocks exposed in the area include thick sequences of carbonate rocks and sequences of metasedimentary and igneous (plutonic and volcanic) rocks. Basin fill and carbonate rock form the principal aquifers in the area, whereas noncarbonate consolidated rock is considered to form confining units.

COMPARISON OF SIMULATION RESULTS FROM FISH SPRINGS MODEL AND RESULTS FROM CARBONATE-ROCK PROVINCE MODEL FOR CORRESPONDING AREA

Ground-water flow as simulated by the Fish Springs model was compared to simulations from the carbonaterock province model for the corresponding area. Simulated water budgets, transmissivity distributions, and simulated hydraulic heads are the three main types of information used in the comparison. This comparison is included herein primarily because most future models probably will include only parts of the carbonate-rock model area. Such a comparison provides an opportunity to evaluate problems with boundary conditions that may occur when only part of a regional flow system is simulated.

\section{SIMULATED WATER BUDGETS}

Simulated water budgets from the Fish Springs and carbonate-rock province models are listed in table 6. Budgets from the two models are not comparable in every way because orientation of the model grids differs slightly and the lateral boundaries are represented differently. In the Fish Springs model, the boundaries are generally no-flow, assigned-flux, or head-dependent flux boundaries. In the carbonate-rock province model, the Fish Springs flow system is one of several internal subsystems. No special conditions are assigned to model cells at the boundary of the Fish Springs flow system. If a ground-water divide exists because of the distributions of recharge, land-surface altitude, and transmissivity, then no simulated flow crosses the boundary. A gradient across the boundary indicates subsurface inflow or outflow. Tc simplify the budget shown in table 6, quantities of subsurface inflow and outflow for both models are net values.

Two comparisons were made: One is an overall budget that includes both the upper and lower layers of the models, and the other is a budget for just the lower layer. For the overall model, the inflow and outflow simulated by the Fish Springs model (about $210 \mathrm{ft}^{3} / \mathrm{s}$ ) was smaller than that simulated by the carbonate-rock province model (about $244 \mathrm{ft}^{3} / \mathrm{s}$ ) for the same area. The difference was only about 16 percent of the inflow and outflow simulated by the Fish Springs model. Considering the potential errors in available hydrologic information and that the models were developed independently, this 16-percent difference indicates relatively good agreement. The main

\section{EXPLANATION}

\section{Regional-scale model area}

Carbonate-rock province

Fish Springs flow system

Model area of basin-fill aquifer, by hydrographic area

(69) Paradise Valley

โ(1)8圆 Stagecoach Valley

โ(105 Carson Valley

โ็ด4 Smith Creek Valley

2844 Milford Area

- - - Boundary of study area, Great Basin Regional Aquifer System

\section{Spring}




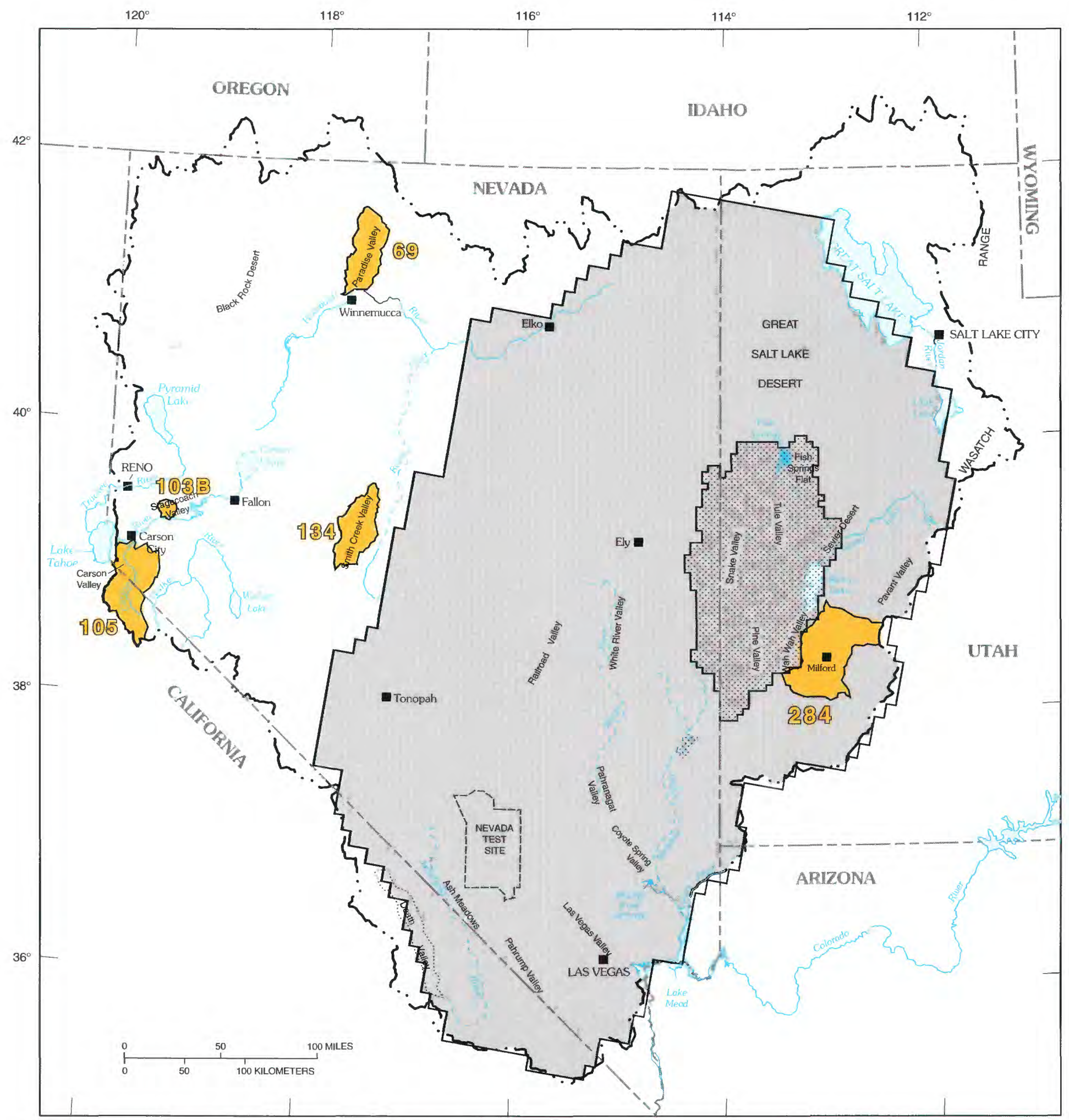

Base from U.S. Geological Survey digital data, 1:100,000, 1978-88, and 1:250,000, 1987 Albers Equal-Area Conic projection

Standard parallels $29^{\circ} 30^{\prime}$ and $45^{\circ} 30^{\prime}$, central meridian $-114^{\circ} 00^{\prime}$

FIGURE 16.-Representative basins, by hydrographic area or subarea (fig. 2, table 1), and regional systems that were used to model ground-water flow in Great Basin Regional Aquifer-System Analysis. 


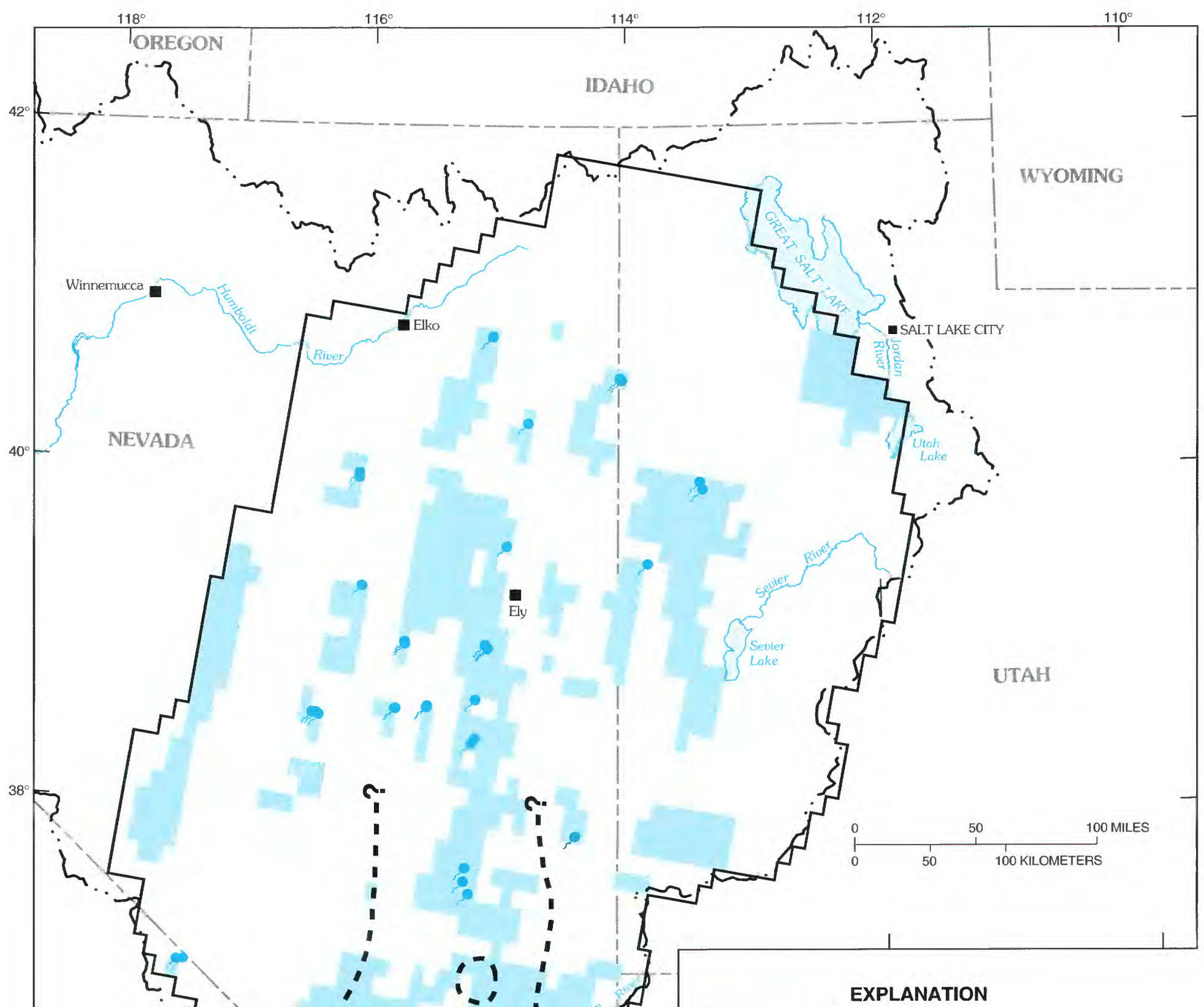

High-transmissivity zone-Shows area where estimated transmissivities in lower layer exceed 0.006 square feet per second

- - - Boundary of central corridor of thick carbonate rocks-Approximately located. Queried where not further delinated. Modified from Dettinger (1989a, p. 14)

ARIZONA

Boundary of carbonate-rock province model

- - - Boundary of study area, Great Basin Regional Aquifer System

Spring used in model simulations

Base from U.S. Geological Survey digital data, 1:100,000, 1978-88, and 1:250,000, 1987

Albers Equal-Area Conic projection

Standard parallels $29^{\circ} 30^{\prime}$ and $45^{\circ} 30^{\prime}$. central meridian $-114^{\circ} 00^{\prime}$

FIGURE 17.-High transmissivity in lower model layer (carbonate-rock aquifers) in relation to springs used in model simulations and to boundary of central corridor of thick carbonate rocks in south-central Nevada. Area of figure is same as for figure 8. 
TABLE 5.-Simulated predevelopment ground-water flow budgets for five deep-flow regions of carbonate-rock province [All values are in acre-feet per year (acre-ft/yr), rounded to nearest 1,000. Modified from Prudic and others (1995)]

\begin{tabular}{|c|c|c|c|c|c|c|}
\hline \multirow[b]{2}{*}{$\begin{array}{l}\text { Budget component and } \\
\text { model layer(s) involved }\end{array}$} & \multicolumn{5}{|c|}{ Deep-flow regions } & \multirow[b]{2}{*}{$\begin{array}{l}\text { Entire } \\
\text { modeled } \\
\text { area }\end{array}$} \\
\hline & $\begin{array}{l}\text { Death } \\
\text { Valley } \\
\text { region }\end{array}$ & $\begin{array}{l}\text { Colorado } \\
\text { River } \\
\text { region }\end{array}$ & $\begin{array}{c}\text { Bonneville } \\
\text { region }\end{array}$ & $\begin{array}{l}\text { Railroad } \\
\text { Valley } \\
\text { region }\end{array}$ & $\begin{array}{l}\text { Upper } \\
\text { Humboldt } \\
\text { River region }\end{array}$ & \\
\hline \multicolumn{7}{|c|}{ Inflow } \\
\hline Mountain recharge (upper layer) & 161,000 & 202,000 & 855,000 & 132,000 & 174,000 & $1,524,000$ \\
\hline $\begin{array}{l}\text { Subsurface inflow from adjacent } \\
\text { region (both upper and lower } \\
\text { layers). }\end{array}$ & ${ }^{1} 16,000$ & 25,000 & 334,000 & ${ }^{4} 2,000$ & ${ }^{5} 12,000$ & $\left({ }^{6}\right)$ \\
\hline Leakage (upper layer) & 0 & 0 & 0 & 0 & ${ }^{7} 3,000$ & 3,000 \\
\hline Total & 177,000 & 207,000 & 889,000 & 134,000 & 189,000 & ${ }^{6} 1,527,000$ \\
\hline \multicolumn{7}{|c|}{ Outflow } \\
\hline Evapotranspiration $^{8}$ (upper layer) & 147,000 & 91,000 & 758,000 & 86,000 & 131,000 & $1,213,000$ \\
\hline Regional springs (lower layer) & 22,000 & 97,000 & 64,000 & 24,000 & 4,000 & 211,000 \\
\hline $\begin{array}{l}\text { Subsurface outflow to adjacent } \\
\text { regions (both upper and lower } \\
\text { layers). }\end{array}$ & ${ }^{9} 3,000$ & ${ }^{10} 10,000$ & ${ }^{11} 8,000$ & 1223,000 & ${ }^{13} 25,000$ & $\left({ }^{6}\right)$ \\
\hline Leakage (upper layer) & ${ }^{14} 8,000$ & 157,000 & ${ }^{16} 59,000$ & 0 & ${ }^{17} 28,000$ & 102,000 \\
\hline Total & 180,000 & 205,000 & 889,000 & 133,000 & 188,000 & ${ }^{6} 1,526,000$ \\
\hline $\begin{array}{l}{ }^{1} \text { Comprises } 8,000 \text { acre-ft/yr from Col } \\
{ }^{2} \text { Comprises 2,000 acre-ft/yr from Bon } \\
{ }^{3} \text { Comprises 4,000 acre-ft/yr from Rail } \\
{ }^{4} \text { Entirely from Bonneville region. } \\
{ }^{5} \text { Comprises } 10,000 \text { acre-ft/yr from Ra } \\
{ }^{6} \text { Net flow among regions within mod } \\
{ }^{7} \text { From Humboldt River and selected t } \\
{ }^{8} \text { Includes evapotranspiration of flow } \\
\text { springs that are simulated to be discharging fro } \\
{ }^{9} \text { Comprises 1,000 acre-ft/yr to upper } \\
{ }^{10} \text { Comprises 2,000 acre-ft/yr to Bonner } \\
{ }^{11} \text { Comprises 5,000 acre-ft/yr to Colora } \\
{ }^{12} \text { Comprises 8,000 acre-ft/yr to Death } \\
\text { to Colorado River region. } \\
{ }^{13} \text { Entirely to Bonneville region. } \\
{ }^{14} \text { Entirely to Death Valley playa, ultim } \\
{ }^{15} \text { Comprises 5,000 acre-ft/yr to Virgin } \\
{ }^{16} \text { Comprises 34,000 acre-ft/yr to Sevier } \\
{ }^{17} \text { To Humboldt River and selected trib }\end{array}$ & $\begin{array}{l}\text { River regior } \\
\text { lle region, } 1,0 \\
\text { Valley region } \\
\text { d Valley regis } \\
\text { area is zero. } \\
\text { aries. } \\
\text { small springs } \\
\text { wer layer. } \\
\text { boldt River r } \\
\text { region and } 8, \\
\text { iver region, } 2 \\
\text { y region, } 10,0\end{array}$ & $\begin{array}{l}\text { re assumed to } \\
\text { e-ft/yr to Dea } 2,000 \text { acre } \\
\text { re-ft/yr to } \mathrm{Ra} \\
\text {-ft/yr to upp }\end{array}$ & $\begin{array}{l}\text { charging from } \\
\text { o Colorado Ri } \\
\text { ey region. } \\
\text { Valley region, } \\
\text { hboldt River r }\end{array}$ & $\begin{array}{l}\text { on. } \\
\text { region, and } 5 \\
\text { d } 600 \text { acre-ft } / \mathrm{y}\end{array}$ & $\begin{array}{l}\text { Death Valley reg } \\
\text { re-ft/yr from Co } \\
\text { n Bonneville reg }\end{array}$ & River region. \\
\hline
\end{tabular}


TABLE 6.-Predevelopment ground-water budgets from Fish Springs ground-water flow model and from carbonate-rock province ground-water flow model for comparable area

[All values are listed in cubic feet per second, which are the units used in the models, and are reported to two decimal places to allow for comparisons of small differences between model estimates]

\begin{tabular}{|c|c|c|}
\hline & \multicolumn{2}{|c|}{$\begin{array}{l}\text { Ground-water budgets } \\
\text { (cubic feet per second) }\end{array}$} \\
\hline & Carbonate-rock province model & Fish Springs model \\
\hline \multicolumn{3}{|c|}{ Upper and lower model layers } \\
\hline \multicolumn{3}{|l|}{ Inflow: } \\
\hline Constant head & 0.00 & 0.00 \\
\hline Constant fluxes ${ }^{1}$ & .00 & 8.90 \\
\hline Springs $^{2}$ & .00 & .00 \\
\hline Recharge & 243.89 & 198.22 \\
\hline Evapotranspiration & .00 & .00 \\
\hline Head-dependent boundaries & .00 & 2.84 \\
\hline Subsurface inflow (net) & .00 & .00 \\
\hline Total & 243.89 & 209.96 \\
\hline \multicolumn{3}{|l|}{ Outflow: } \\
\hline Constant head & 0.00 & 0.00 \\
\hline Constant fluxes ${ }^{1}$ & .00 & 9.66 \\
\hline Springs $^{2}$ & 41.01 & 39.02 \\
\hline Recharge & .00 & .00 \\
\hline Evapotranspiration & 155.82 & 161.76 \\
\hline Head-dependent boundaries & 15.76 & .00 \\
\hline Subsurface outflow (net) & 31.32 & .00 \\
\hline Total & 243.91 & 210.44 \\
\hline \multicolumn{3}{|c|}{ Lower model layer } \\
\hline \multicolumn{3}{|l|}{ Inflow: } \\
\hline Constant head & 0.00 & 0.00 \\
\hline Constant fluxes ${ }^{1}$ & .00 & 5.52 \\
\hline Springs ${ }^{2}$ & .00 & .00 \\
\hline Recharge & .00 & .00 \\
\hline Evapotranspiration & .00 & .00 \\
\hline Head-dependent boundaries & .00 & 2.76 \\
\hline Inflow from top layer (net) & 38.42 & 30.24 \\
\hline Subsurface inflow (net) & 2.59 & .00 \\
\hline Total & 41.01 & 38.52 \\
\hline \multicolumn{3}{|l|}{ Outflow: } \\
\hline Constant head & 0.00 & 0.00 \\
\hline Constant fluxes ${ }^{1}$ & .00 & .00 \\
\hline Springs $^{2}$ & 41.01 & 39.12 \\
\hline Recharge & .00 & .00 \\
\hline Evapotranspiration & .00 & .00 \\
\hline Head-dependent boundaries & .00 & .00 \\
\hline Outflow to top layer (net) & .00 & .00 \\
\hline Subsurface outflow (net) & .00 & .00 \\
\hline Total & 41.01 & 39.12 \\
\hline
\end{tabular}

${ }^{1}$ Assigned values simulated by well functions.

${ }^{2}$ Values simulated by drain functions. 
differences are that in the carbonate-rock province model a larger value of recharge was assigned, and in the Fish Springs model this was not fully offset by inflow from head-dependent boundaries and some assigned recharge (simulated as inflow from wells). The difference in simulated evapotranspiration was only about 4 percent. However, the smaller grid size of the Fish Springs model allowed a more refined depiction of the simulated area of evapotranspiration. Simulated outflow differed primarily in that the carbonate-rock model allowed for a net subsurface outflow of about $31 \mathrm{ft}^{3} / \mathrm{s}$, whereas the Fish Springs model simulated none. However, the carbonate-rock model simulated the combined net outflow from headdependent boundaries and subsurface outflow as about $47 \mathrm{ft}^{3} / \mathrm{s}$. In contrast, the Fish Springs model simulated no net subsurface outflow from head-dependent boundaries and only about $10 \mathrm{ft}^{3} / \mathrm{s}$ net subsurface outflow as discharge from wells (assuming constant fluxes). Thus, the larger amount of inflow simulated in the corresponding area of the carbonate-rock model is discharged primarily by subsurface outflow.

For the lower model layer, the inflow and outflow simulated by the carbonate-rock model (about $41 \mathrm{ft}^{3} / \mathrm{s}$ ) was larger than that simulated by the Fish Springs model (about $39 \mathrm{ft}^{3} / \mathrm{s}$ ). The difference was only about 5 percent. This agreement is close because in both models the outflow represents only discharge from Fish Springs. Simulated inflow to the lower layer consisted primarily of downward leakage from the upper layer in both models. The carbonate-rock model simulated some additional net subsurface inflow, and the Fish Springs model simulated some additional subsurface inflow (simulated by wells and head-dependent boundaries).

The budgets for the carbonate-rock and Fish Springs ground-water flow models are similar in many aspects. Most of the differences noted are due to differences in assigned conditions at the boundary of the Fish Springs model as contrasted to calculated flows along the Fish Springs model boundary in the carbonate-rock model.

\section{TRANSMISSIVITY DISTRIBUTIONS}

Transmissivity distributions in the lower layer of the Fish Springs and carbonate-rock province models are shown in figure 19. Transmissivity values in the lower layer of each model are not strictly comparable because simulating anisotropic conditions in the lower layer of the Fish Springs model resulted in an improved fit of the hydraulic-head data used for calibration. The best fit was obtained when transmissivity in the north-south direction was greater than transmissivity in the east-west direction by factor of 1.5 (Carlton, 1985, p. 76). The northsouth direction was used for the lower layer of the Fish Springs model (fig. 19A) because that direction better par- allels regional flow. Isotropic values of transmissivity were used in the carbonate-rock province model (fig. 19B).

Transmissivity distributions from the Fish Springs and the carbonate-rock province models show similar areas of relatively high and low values. However, values for the lower layer of the Fish Springs model are generally larger than the values for the lower layer of the carbonate-rock province model. The larger values are due in part to the previously discussed factor of directional anisotropy in the Fish Springs model. They are also due to the fact that simulated subsurface inflow and outflow across the Fish Springs flow-system boundary in the carbonate-rock province model produced a higher flux in the lower layer. This allowed the observed hydraulic-head distribution to be matched by using lower values of transmissivity.

The most significant similarity between the two transmissivity distributions is that both indicate an area of high transmissivity beneath parts of Tule Valley and the House Range. In the carbonate-rock model the area of highest transmissivity is offset slightly to the west and lies principally beneath Tule Valley. However, both models support the conclusion that the House Range and parts of adjacent Tule Valley act as a regional subsurface drain that transports water north to Fish Springs and adjacent discharge areas.

\section{SIMULATED HYDRAULIC HEADS}

Simulated hydraulic heads in the upper and lower layers of the Fish Springs and carbonate-rock province models indicate the same general pattern of ground-water flow. Ground water flows from recharge areas that are along the southwest boundary of the modeled area northward and eastward toward the regional discharge area in Fish Springs Flat at the northeast corner of the modeled area. However, the two models also differ significantly. For example, water-level contours simulated for the upper layer (basin-fill deposits) in the eastern and southern parts of the modeled area (Sevier Desert, Wah Wah Valley, Pine Valley, and southern Snake Valley) are consistently higher in the carbonate-rock province model than in the Fish Springs model (fig. 20A). Moreover, contours of heads simulated by the carbonate-rock model indicate subsurface inflow along the southeast boundary of the modeled area and contours simulated by the Fish Springs model indicate little inflow along this boundary.

Simulated hydraulic heads in the lower layer of the two models (fig. 20B) show the same general differences as previously discussed regarding the upper model layer. In the lower layer, heads simulated by the carbonate-rock province model are higher than heads simulated by the Fish Springs model throughout almost all the area represented by the Fish Springs model. 
Differences in the simulated hydraulic heads are attributed primarily to differences in simulated subsurface inflow and outflow at the boundary of the Fish Springs model area. Also, transmissivity values used in the carbonate-rock province model are lower than those used in the Fish Springs model. This difference caused the carbonate-rock province model to simulate higher heads, assuming similar fluxes for the two models.

\section{SIMULATION OF GROUND-WATER FLOW IN BASIN-FILL AQUIFERS}

The Great Basin RASA study area includes 260 hydrographic areas. Most contain a basin-fill aquifer and include the drainage area of adjacent mountains. Because not all basin-fill aquifers could be modeled, the approach taken was to model selected areas that represent the large range of conditions across the study area. The five hydrographic areas that were selected (fig. 16) are the Milford Area in Utah and Carson, Paradise, Smith Creek, and Stagecoach Valleys in Nevada (Thomas, Carlton, and Hines, 1989; Harrill and Preissler, 1994; Prudic and Wood, 1995; Prudic and Herman, 1996; Mason, 1998). In general, the Milford area represents a large basin-fill reservoir under sustained development; Carson Valley represents a basin-fill aquifer dominated by a through-flowing river; Paradise Valley represents a basin-fill reservoir having an upgradient part dominated by streams and an arid lower part; Smith Creek Valley represents a topographically closed, arid basin; and Stagecoach Valley represents a small, topographically closed basin that is partly drained by subsurface outflow.

Each basin-fill aquifer was simulated by using the USGS finite-difference ground-water flow model developed by McDonald and Harbaugh (1988). In each valley, the basin-fill aquifer was modeled as a three-dimensional system composed of two or three layers (fig. 21). This concept can be applied to many parts of the Great Basin, although, depending on specific conditions, use of fewer than or more than the three layers shown in figure $21 B$ may be desirable. Selected characteristics and hydraulic properties of the five basin-fill aquifer models are listed in table 7.

Each model was used to simulate several hypothetical development scenarios that illustrate effects of variations in pumping rate, location of pumping, and the degree to which pumping was concentrated. Pumping rates were normalized in terms of the simulated steady-state (predevelopment or natural) recharge to and discharge from each basin-fill aquifer.

Rates equal to or twice the simulated steady-state recharge and discharge were used to simulate the development scenarios. Pumping location was approximately standardized relative to areas of natural discharge. The degree to which pumping was concentrated was simulated by either distributing the pumping locations or concentrating the pumping at one location.

Standard scenarios using selected combinations of the above factors were run with each of the five models. Because the objective was to illustrate the long-term response to pumping, the modeled systems were stressed for simulated 300-yr periods and then allowed to recover for $300 \mathrm{yr}$. Shorter pumping periods were used in several of the model runs for scenarios where concentrated pumping caused large drawdowns. One scenario involved variable pumping. In that scenario, the modeled systems were stressed for $50 \mathrm{yr}$ at twice the rate of recharge and discharge and then pumping was reduced to a rate equal to the steady-state recharge and discharge and the simulation was continued for another $250 \mathrm{yr}$.

Simulated responses of the five models to the scenario in which pumping equals the steady-state recharge and discharge and wells are distributed strategically to capture discharge are compared in table 8. In all five models the long-term maximum water-level declines were minimal (ranging from 20 to $99 \mathrm{ft}$ ) and a new equilibrium was either approached or attained by the end of the 300-yr pumping period. The results of this scenario suggest that if pumping is located strategically with respect to areas of natural discharge, then management of basins on the basis of a sustained-yield concept may be a viable option. If pumping is not located strategically with respect to discharge or is highly concentrated, the sustained-yield concept may not be viable because excessive drawdowns may occur before all natural discharge is captured.

Simulated responses of the five models to other scenarios indicated that location of pumping and the degree to which pumping is concentrated are factors that can be as significant as the overall pumping rate in determining the response to development by pumping. Also, the location of pumping with respect to streams and rivers in hydraulic continuity with the ground-water system is important in determining the response to pumping.

The long-term drawdowns for the scenarios in which a variable pumping rate was used were about the same as for scenarios with similar distributions of pumping held equal to the steady-state recharge and discharge for the entire $300-y r$ pumping period. This scenario illustrated the feasibility of managing basins under an optimal-yield concept, by which the overall pumping rate was allowed to exceed the steady-state recharge and discharge for a short period of time instead of being limited to the steadystate recharge and discharge throughout the entire period of pumping. 
A

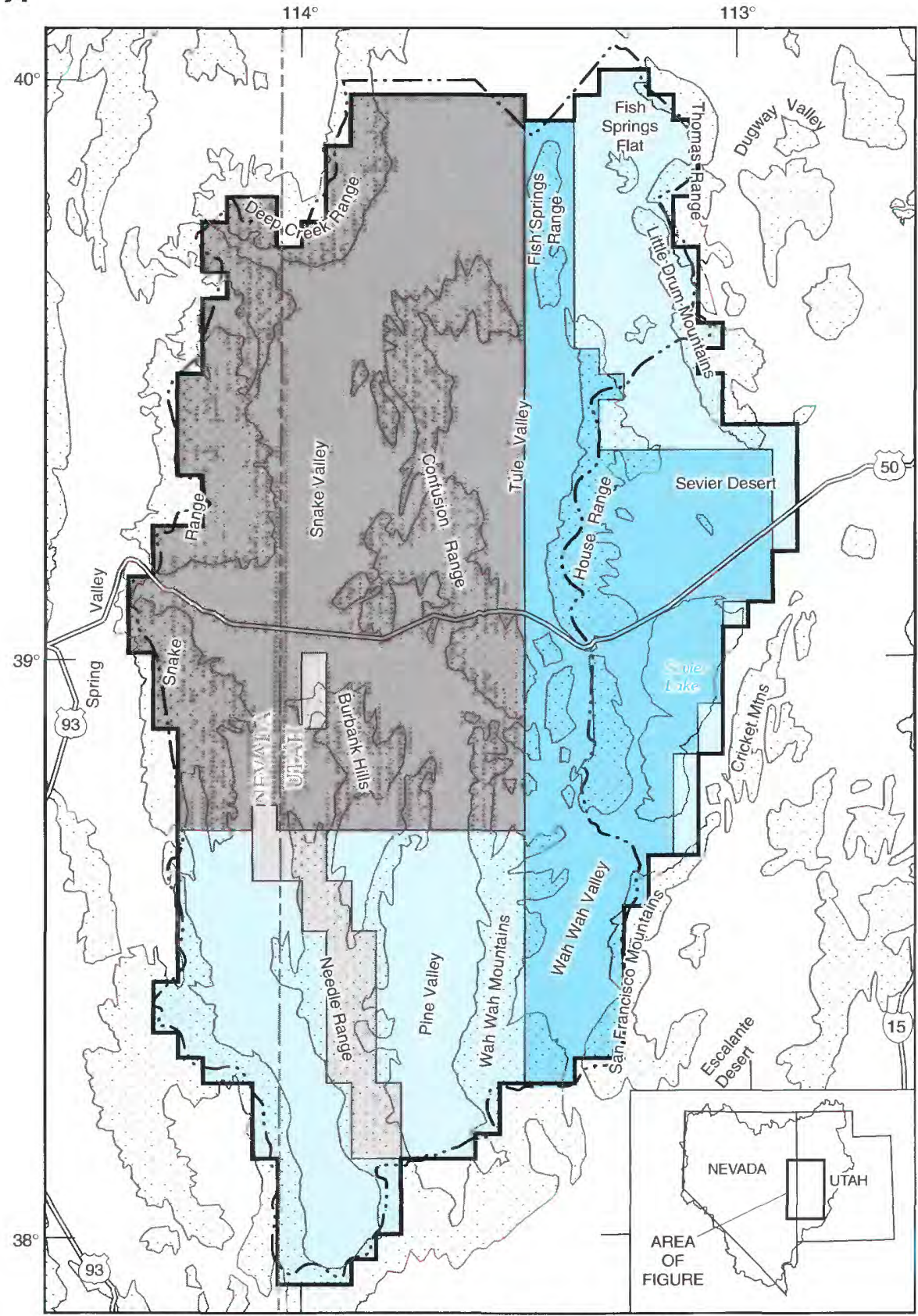

Base from U.S. Geological Survey digital data, 1:100,000, 1978-88, and 1:250,000, 1987

Albers Equal-Area Conic projection

Standard parallels $29^{\circ} 30^{\prime}$ and $45^{\circ} 30^{\prime}$, central meridian $-114^{\circ} 00^{\prime}$

\section{EXPLANATION}

Basin fill

Consolidated rock

Transmissivity, in feet squared per second

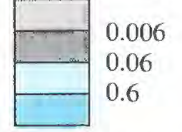

\section{- -.- Boundary of Fish Springs} ground-water flow system

Boundary of active cells in Fish Springs model

Spring

FIGURE 19.--Transmissivity in lower layers of ground-water flow models. A, Fish Springs flow system (Carlton, 1985). B, Carbonate-rock province (Prudic and others, 1995). 


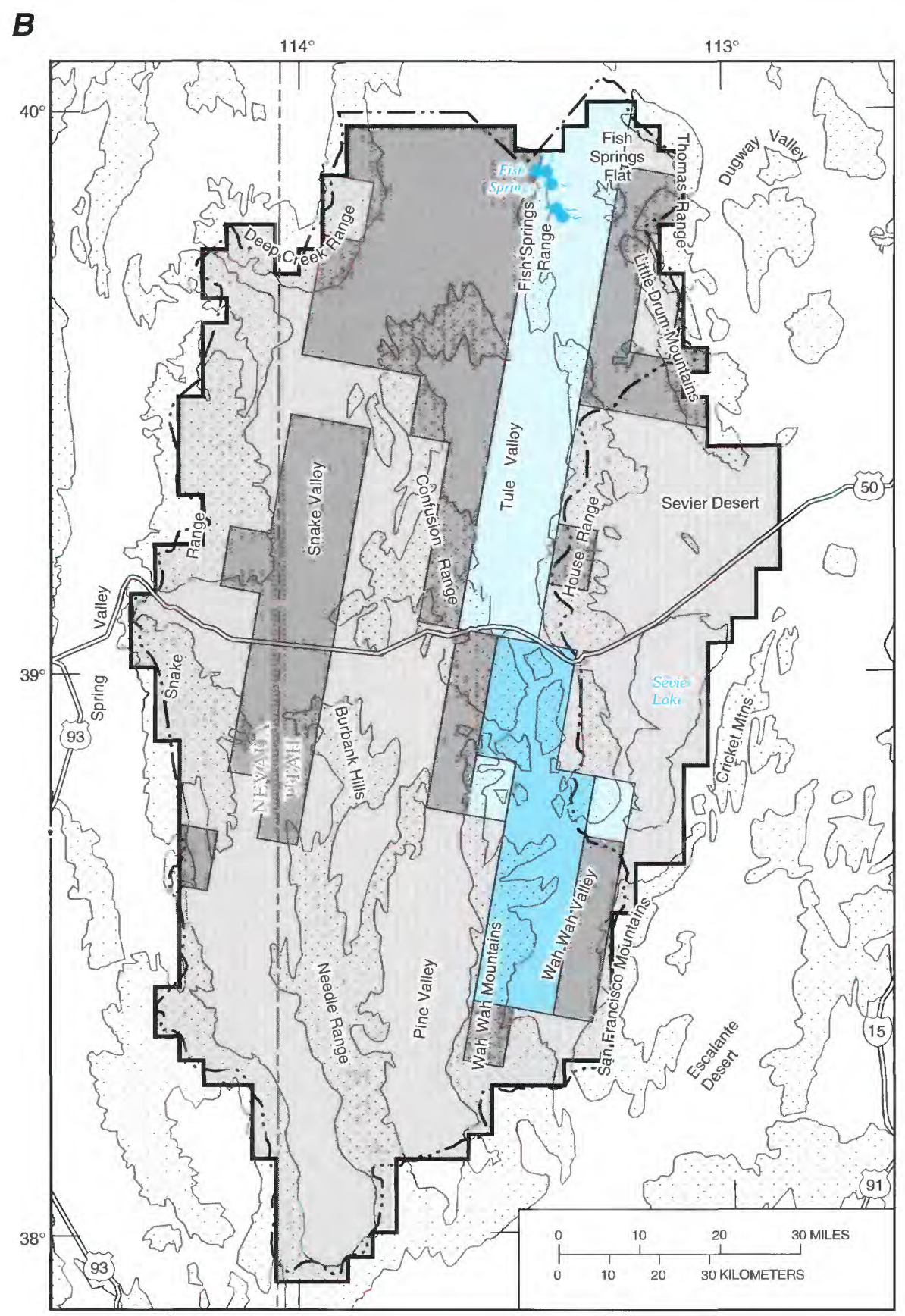


$\boldsymbol{A}$

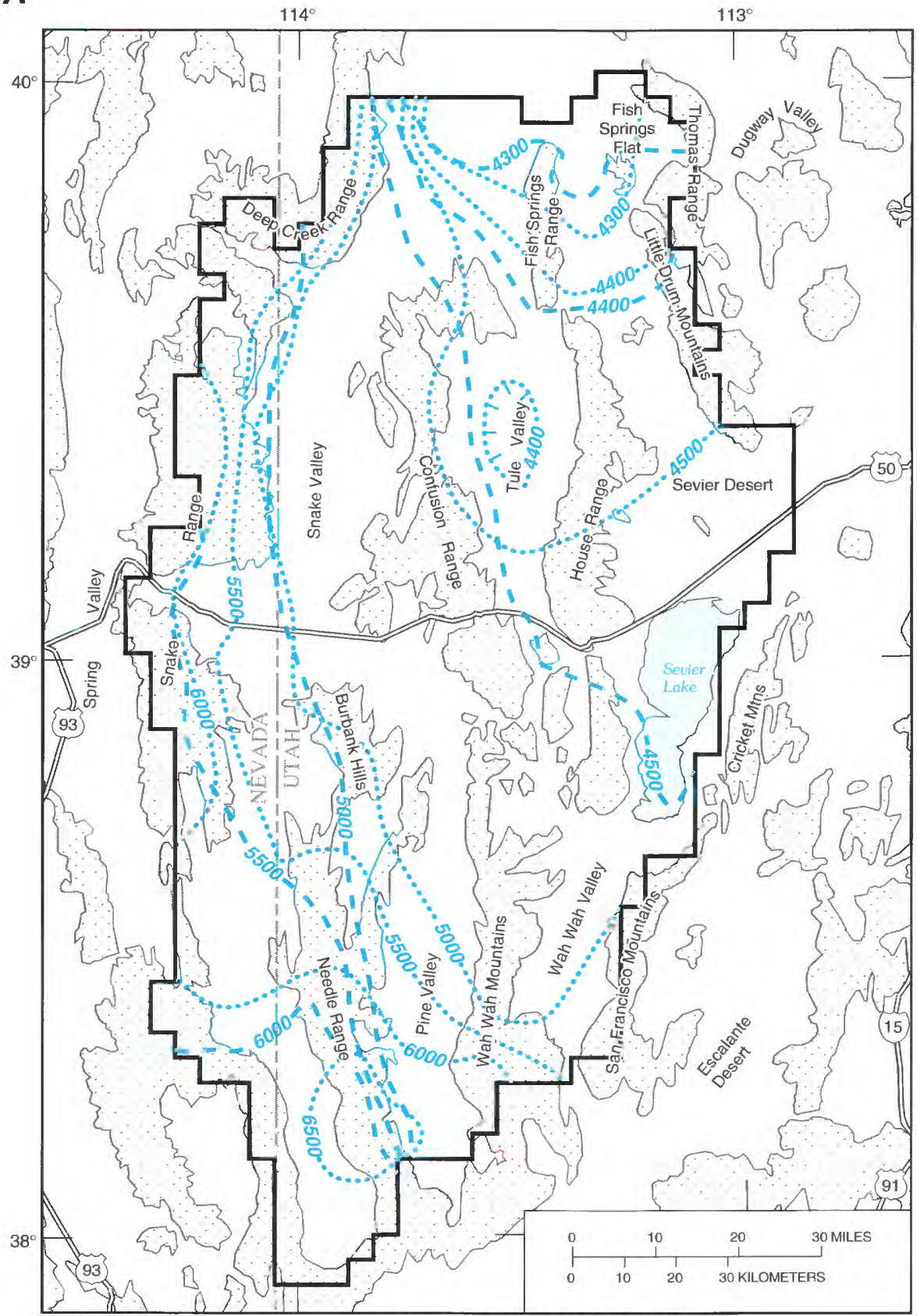




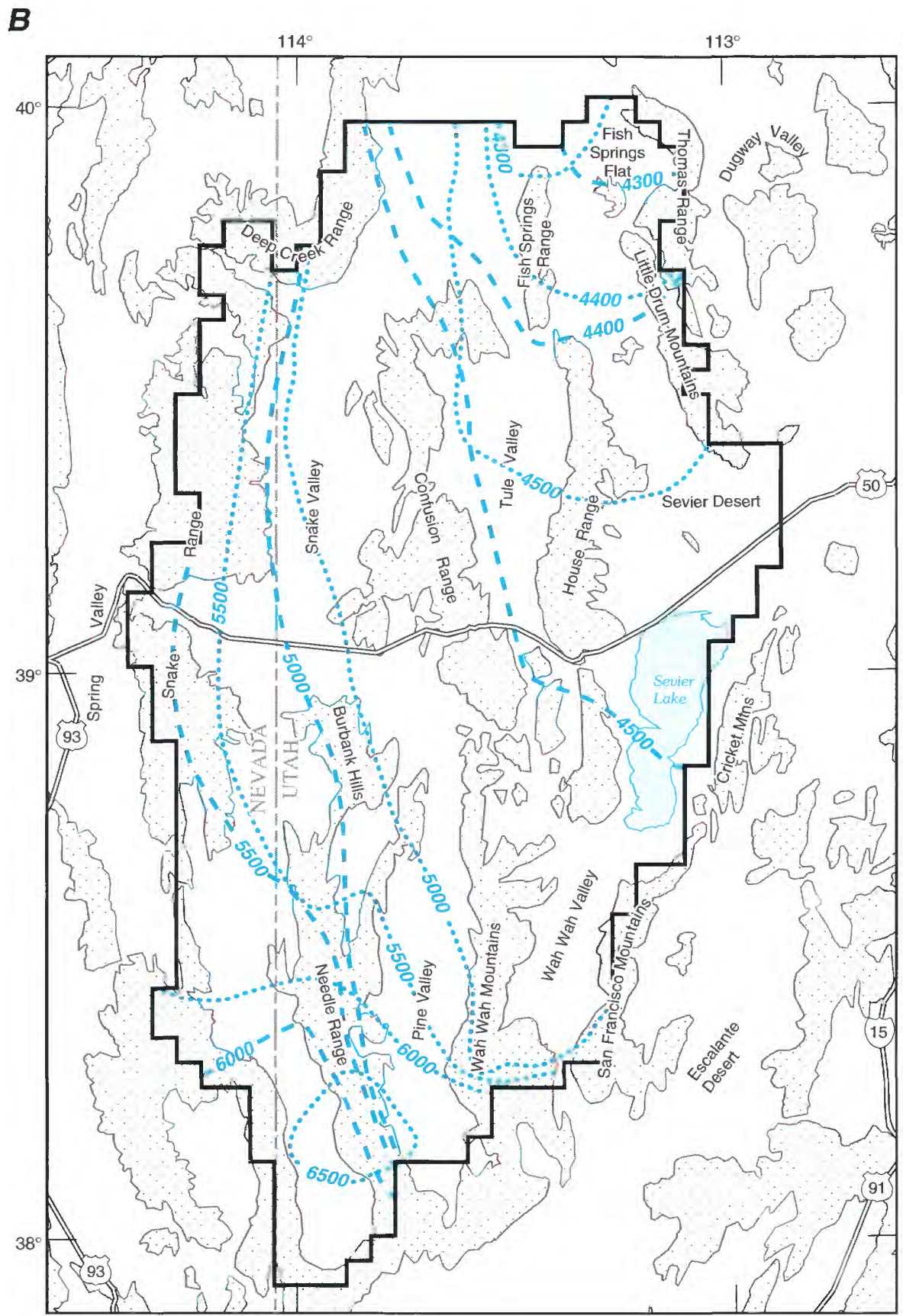


A
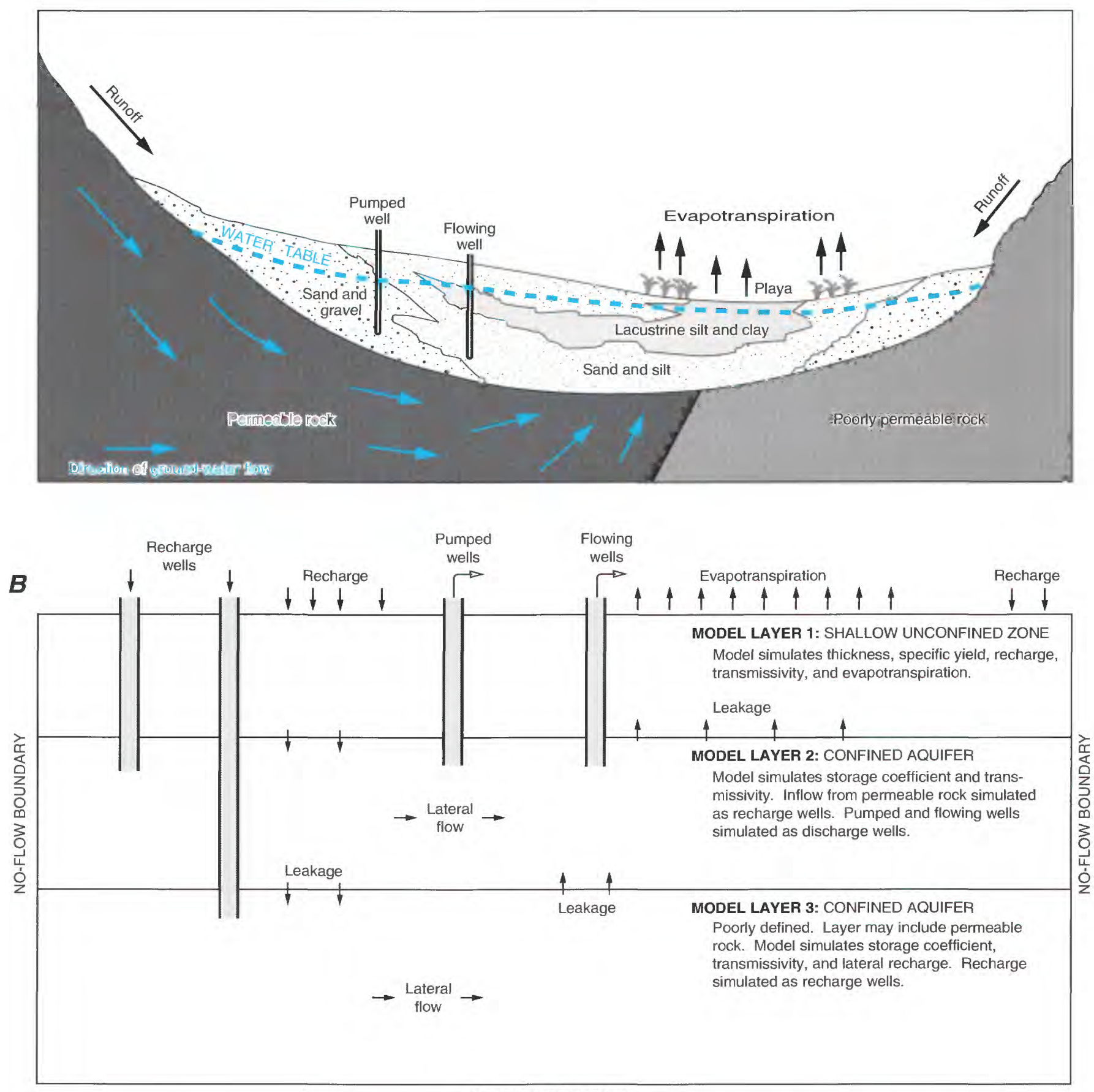

NO-FLOW BOUNDARY

FIGURE 21.-Basin-fill aquifer. A, Generalized hydrogeologic section. B, Layers simulated by three-dimensional finite-difference model to represent flow system in aquifer. 
TABLE 7.-Selected characteristics and hydraulic properties of five basin-fill aquifer models used in this study

[ $>$, greater than. \%, percent. —, not applicable or no data]

\begin{tabular}{lccccc}
\hline & Milford area ${ }^{1}$ & Carson Valley & Paradise Valley & Smith Creek Valley & Stagecoach Valley \\
\hline \multicolumn{5}{c}{ Area, in square miles } \\
\hline Basin area & 1,160 & 444 & $>600$ & 583 & 70 \\
$\begin{array}{l}\text { Area represented by active } \\
\text { model cells. }\end{array}$ & 589 & 171 & 325 & 228 & 30.1 \\
\hline
\end{tabular}

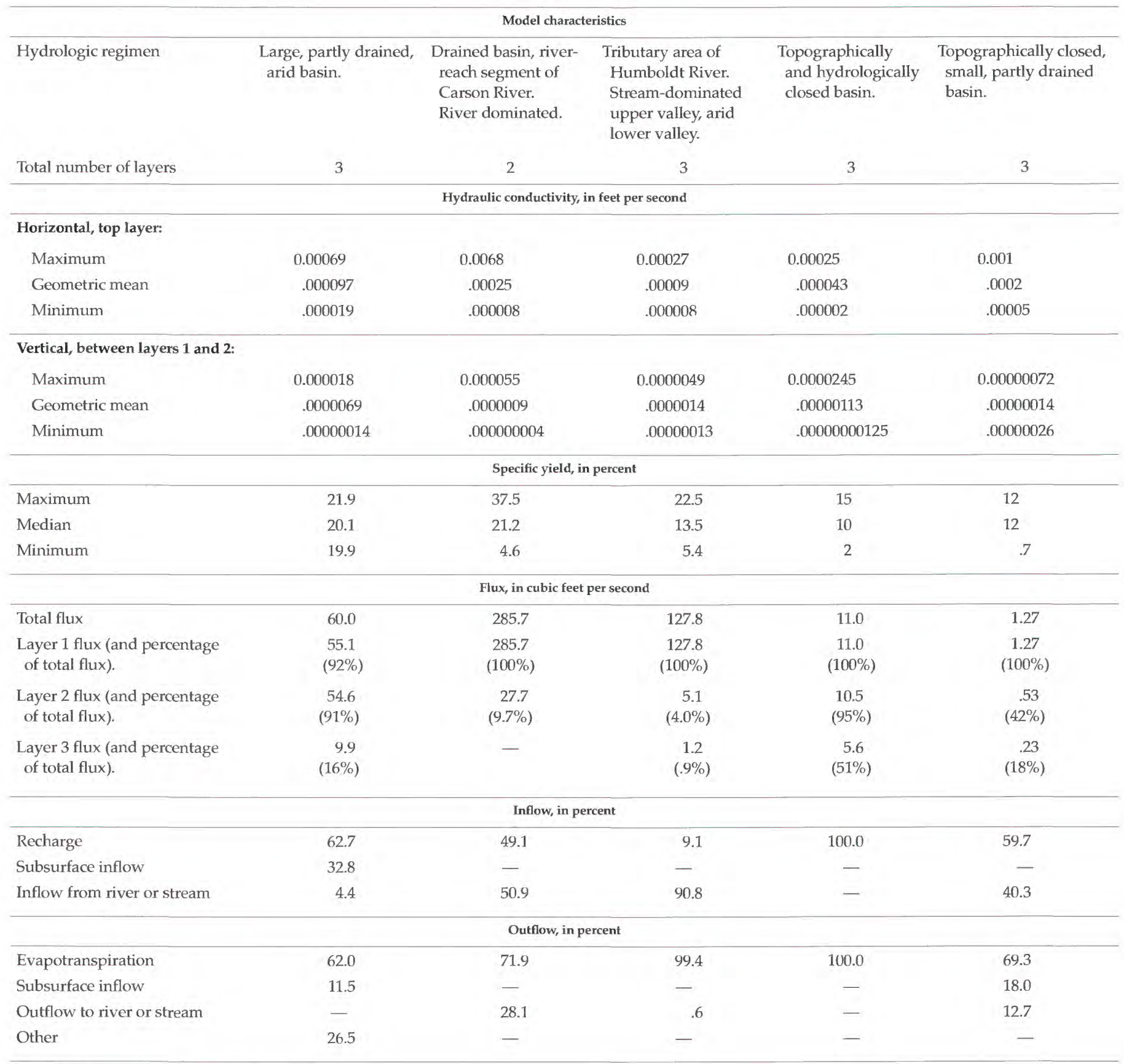

\footnotetext{
${ }^{1}$ Hydrographic area 284 (see fig. 2 and table 1).
} 
TABLE 8.-Simulated responses to pumping scenario where pumping equals estimated natural recharge and discharge and is distributed strategically to capture discharge

[do. or Do., ditto]

\begin{tabular}{|c|c|c|c|c|c|c|}
\hline Area $^{1}$ & $\begin{array}{l}\text { Pumping } \\
\text { rate } \\
\text { (acre-feet } \\
\text { per year) }\end{array}$ & $\begin{array}{c}\text { Maximum } \\
\text { water-level } \\
\text { decline in cell } \\
\text { (feet) }\end{array}$ & $\begin{array}{l}\text { Recovery } 300 \text { years after } \\
\text { end of pumping }\end{array}$ & New equilibrium & $\begin{array}{c}\text { Cumulative storage depletion } \\
\text { after } 300 \text { years of pumping } \\
\text { (acre-feet) }\end{array}$ & $\begin{array}{l}\text { Principal source of water } \\
\text { after } 300 \text { years of pumping }\end{array}$ \\
\hline Milford area & 43,400 & 60 & Almost complete & Approached & $2,555,000$ & $\begin{array}{l}\text { Reduction in evapotran- } \\
\text { spiration. }\end{array}$ \\
\hline Carson Valley & 100,000 & 45 & Complete & Attained & 160,000 & $\begin{array}{l}\text { Decreased seepage to } \\
\text { and increased leakage } \\
\text { from Carson River and } \\
\text { from ditches. }\end{array}$ \\
\hline Paradise Valley & 72,000 & 99 & .......do.................... & Approached & $1,000,000$ & $\begin{array}{l}\text { Reduction in evapotran- } \\
\text { spiration. }\end{array}$ \\
\hline Smith Creek Valley & 8,000 & 20 & .......do.................... & Attained & $2,200,000$ & 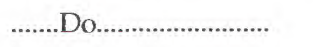 \\
\hline Stagecoach Valley & 920 & 28 & ........do......................... & ........do........... & 26,000 & 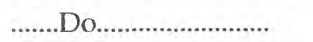 \\
\hline
\end{tabular}

\footnotetext{
${ }^{1}$ Model area or hydrographic area (see fig. 2 and table 1).
}

\section{WATER QUALITY AND GEOCHEMISTRY}

Water in the principal aquifers of the Great Basin contains generally less than $1,000 \mathrm{mg} / \mathrm{L}$ dissolved solids except in natural-discharge and geothermal areas. Aquifers in industrial, mining, urbanized, and agricultural areas and aquifers containing highly soluble evaporative salts and other less soluble minerals also may have dissolved-solids concentrations greater than $1,000 \mathrm{mg} / \mathrm{L}$, or elevated concentrations of undesirable constituents, or both. The general distribution of areas where the dissolved-solids concentration exceeds $1,000 \mathrm{mg} / \mathrm{L}$ is shown in figure 22.

The dissolved solids in water in basin-fill aquifers of the western Great Basin generally are dominated by sodium, calcium, and bicarbonate; in basin-fill aquifers of the eastern Great Basin by calcium, sodium, magnesium, and bicarbonate; and in carbonate-rock aquifers of the eastern Great Basin by calcium, magnesium, and bicarbonate. The dissolved solids in water concentrated by evapotranspiration in discharge areas generally are dominated by sodium, chloride, and sulfate.

Described in the next two sections are the geochemical and hydrologic processes responsible for the major-ion chemistry and isotopic composition of water in aquifers throughout the Great Basin for representative examples of the two principal types of flow systems in the Great Basin: a hydrologically closed basin-fill aquifer in Smith Creek Valley (west-central Nevada) and a regional carbonate-rock aquifer system (southern Nevada).

\section{SMITH CREEK VALLEY BASIN-FILL AQUIFER}

Chemical and isotopic compositions of water in the basin-fill aquifer in Smith Creek Valley (fig. 23; Thomas and others, 1996) evolve because of (1) evapotranspirative concentration of the water, (2) dissolution of minerals and soil-zone carbon dioxide gas, (3) precipitation of minerals or formation of minerals by incongruent dissolution, and (4) ion exchange. Recharge originates mainly as precipitation in the surrounding Desatoya and Shoshone Mountains and New Pass Range. Solutes in this precipitation are concentrated by evapotranspiration. The water then infiltrates the soil zone and obtains additional ions by dissolving carbon dioxide gas and volcanic rock (groundmass and phenocrysts, dominantly plagioclase feldspar) and thus produces a sodium-calcium bicarbonate water. In addition, small amounts of alkali feldspar, gypsum, biotite, and possibly pyrite, illite, and chlorite are dissolved, each adding ions to the water. Chalcedony precipitates and thus removes ions from the water, and kaolinite (or some other clay mineral) forms as the result of incongruent dissolution of the feldspars.

\section{EXPLANATION}

Total dissolved solids greater than 1,000 milligrams per liter

Boundary of study area, Great Basin Regional Aquifer System 


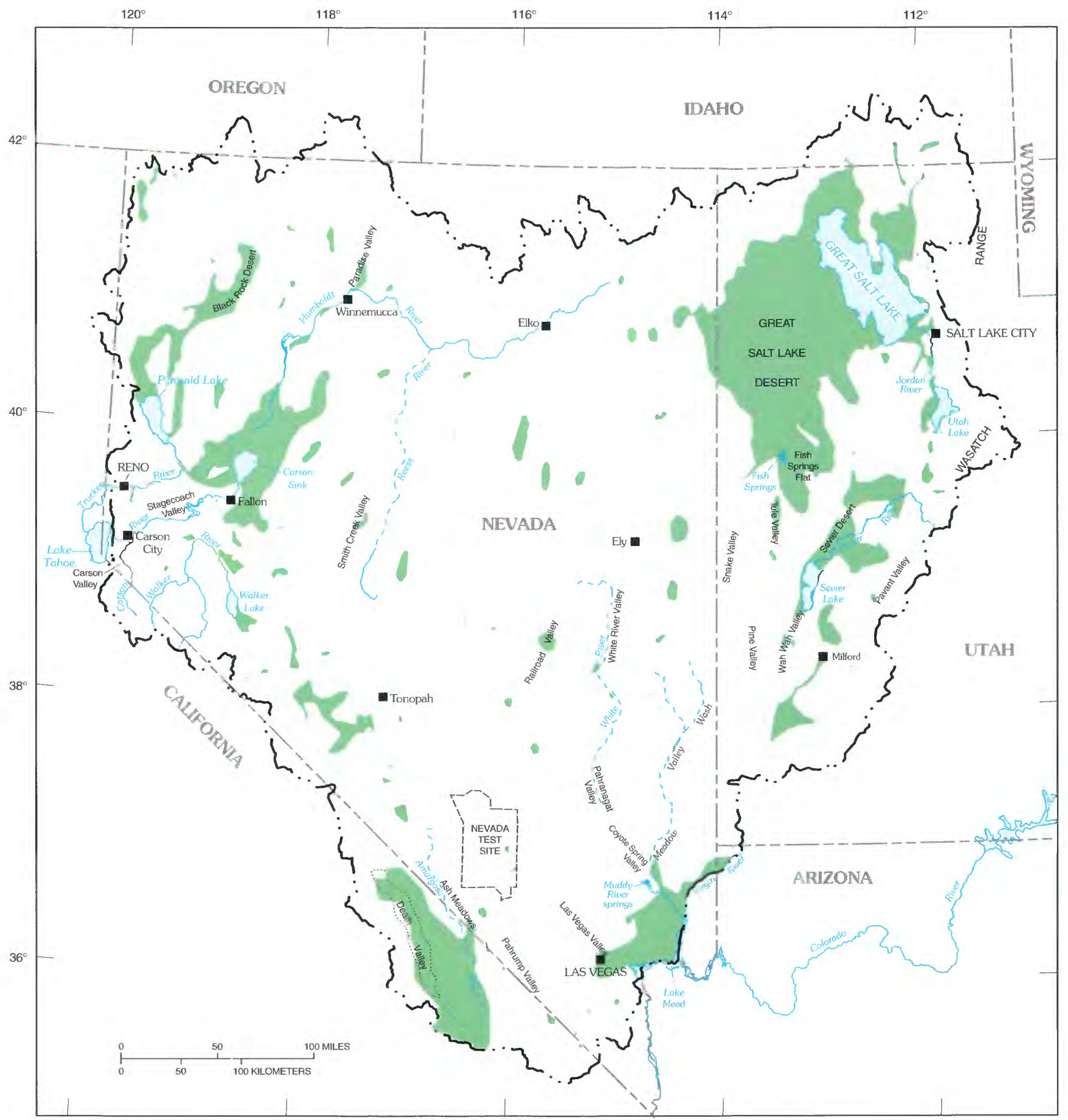

Base from U.S. Geological Survey digital data, 1:100,000, 1978-88, and 1:250,000, 1987

Albers Equal-Area Conic projection,
Standard parallels $29^{\circ} 30^{\prime}$ and $45^{\circ} 30^{\prime}$, central meridian $-114^{\circ} 00^{\prime}$

FIGURE 22.-Areas where dissolved-solids concentration in water from principal aquifers in Great Basin study area exceeds 1,000 milligrams per liter. Modified after J.M. Thomas (written commun., 1995). 


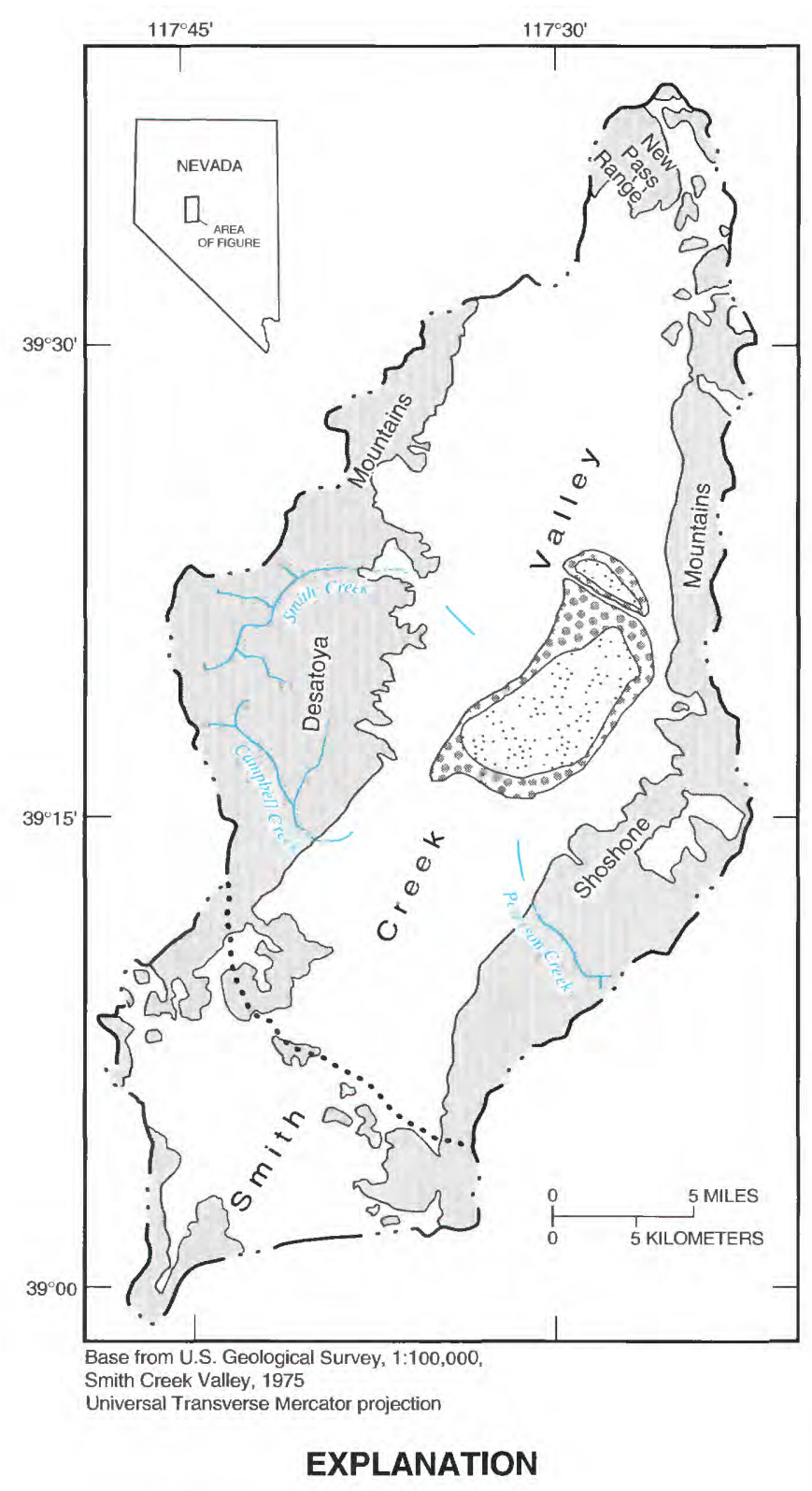

Basin fill

Consolidated rock

Playa deposits

Phreatophytes

_... Smith Creek Valley Hydrographic Area boundary

....... Ground-water divide - Approximately located

FIGURE 23.--Location and general hydrologic features of Smith Creek Valley Hydrographic Area. Modified from Thomas and others (1996).
Calcium and magnesium in the water exchange for sodium in clays in the playa area, where vasin-fill deposits grade from coarser to finer grained sediments. This ion exchange results in the sodium-calcium bicarbonate water evolving into a sodium bicarbonate water. Calcium also may be removed from the water by the weathering of plagioclase to $\mathrm{Ca} / \mathrm{Na}$-montmorillonite and the precipitation of a zeolite mineral.

Evapotranspiration, dissolution of chloride-containing evaporative salts, and precipitation of calcite and zeolite minerals are the main processes affecting ground-water chemistry in the discharge area. These processes result in the evolution of sodium bicarbonate water into a sodium chloride water. Constituents also are added by dissolution of plagioclase and alkali feldspars, gypsum (or other sulfate-containing evaporative salts), and chlorite, whereas kaolinite is formed by incongruent dissolution. Evapotranspiration of shallow ground water in the discharge area causes proportions of the isotopes deuterium and oxygen-18 to increase relative to those of hydrogen -1 and oxygen- -16 , respectively.

\section{CARBONATE-ROCK AQUIFERS OF SOUTHERN NEVADA}

Chemical and isotopic compositions of water in the carbonate-rock aquifers of southern Nevada (Thomas and others, 1996) evolve because of (1) dissolution of minerals and soil-zone carbon dioxide gas, (2) precipitation or formation of minerals, (3) ion exchange, (4) mixing of chemically or isotopically different waters, and (5) geothermal heating. Recharge originates primarily as precipitation in the Spring Mountains and Sheep Range (fig. 15). Solutes in this precipitation are concentrated by evapotranspiration. The water then infiltrates the soil zone and obtains additional ions by dissolving carbon dioxide gas, calcite, and dolomite. Recharge waters generally are saturated with respect to both calcite and dolomite and contain predominantly calcium, magnesium, and bicarbonate. These waters then circulate to depths sufficient to be affected by geothermal heating, which precipitates calcite.

Throughout the carbonate-rock aquifers, the following geochemical processes occur: dedolomitization (dissolution of gypsum, which causes dolomite to dissolve and calcite to precipitate), exchange of calcium and magnesium in the water for sodium in clays; precipitation of chalcedony; formation of kaolinite; and, in some spring areas, exsolution of carbon dioxide gas. In addition, sodium and potassium probably are added to the water by the dissolution of volcanic rock (glass and minerals, dominantly sodic plagioclase and alkali feldspar) and of 
zeolite minerals (probably clinoptilolite), which are present in parts of the study area. Locally, calcium, sodium, sulfate, and chloride are added by dissolution of gypsum and halite. In the Ash Meadows flow system, a subsystem of the Death Valley ground-water flow system (fig. 15), downward leakage of water dissolves sodium and sulfate from the overlying fine-grained basin fill and volcanic-rock confining unit. As a result, sodium and sulfate concentrations increase in the carbonate-rock aquifers. Thus, outside the recharge areas of the carbonaterock aquifers in southern Nevada, sodium, sulfate, and chloride can be major constituents dissolved in the water.

Waters from different areas have different chemical and isotopic compositions. The mixing of these waters in the carbonate-rock aquifers can result in water that is chemically and isotopically different from the source waters. However, all the mixed waters generally are undergoing the same geochemical processes, which result in waters of similar chemical composition in the carbonate-rock aquifers irrespective of source. Thus, the modified isotopic composition of the mixed water, as compared to the mixing (source) waters, is the primary evidence of mixing in the carbonate-rock aquifers.

The isotopic and chemical compositions of waters were used to delineate ground-water flow paths in the carbonate-rock aquifers of southern Nevada (fig. 24; Thomas and others, 1996). First, the deuterium content of water in the carbonate-rock aquifer was used to determine source areas, flow paths, and mixing. Second, these deuteriumdelineated flow paths and mixing patterns were checked for chemical feasibility by using mass-balance and mineral-equilibrium models based on water chemistry and geochemical processes that are assumed to have produced the chemical composition of the water. Third, adjusted carbon-14 ages were determined from carbonisotope data on the basis of the mass-balance reaction models. These ages provide another check on the flow path and mixing patterns because ground-water ages must increase down flow paths or must change due to mixing of different-age waters.

These isotopic and geochemical models produced the following results (see figs. 15 and 24; listed flow quantities are rounded off to the nearest 1,000 acre feet):
(1) Ground water discharging at Muddy River springs (the terminus of the White River flow system, which is a subsystem of the Colorado River ground-water flow system) is a mixture of 40 percent $(14,000$ acre-ft/ yr) from Pahranagat Valley, 38 percent $(14,000 \mathrm{acre}-\mathrm{ft} / \mathrm{yr})$ from the Sheep Range, and 22 percent $(8,000$ acre- $\mathrm{ft} / \mathrm{yr})$ from the southern Meadow Valley Wash.

(2) Ground water discharging at the terminus of the Ash Meadows flow system (Ash Meadows springs) is a mixture of 60 percent $(10,000$ acre$\mathrm{ft} / \mathrm{yr}$ ) from the Spring Mountains and 40 percent $(7,000$ acre-ft/yr) from Pahranagat Valley.

(3) Almost all ground water in Las Vegas Valley comes from recharge in the Spring Mountains. (The Sheep Range may supply 2,500 acre-ft/yr or less to northern Las Vegas Valley.)

(4) All ground water in Pahrump Valley comes from recharge in the Spring Mountains.

Flow velocities calculated from adjusted carbon-14 ages are less than velocities calculated from hydrologic data. These differences are summarized for areas studied by Thomas and others (1996) in table 9. This discrepancy in velocities indicates that the ages or average hydraulic conductivity may be overestimated, or the effective porosity and horizontal-flow path lengths may be underestimated, or both. Ground-water ages are sensitive to the carbon-13 composition of the dissolving calcite. Thus the ages could be overestimated if more vein calcite, which has lighter carbon-13 composition than the primary calcite, is exchanging carbon with the water than the 50 percent assumed for determining ages for flow-velocity estimates. However, age-calculated flow velocities, 9.6 to $144 \mathrm{ft} / \mathrm{yr}$, are in the range of velocities simulated for the Madison aquifer in Montana, Wyoming, and South Dakota (Downey, 1984). The Madison aquifer is a carbonate-rock aquifer similar to the carbonate-rock aquifers of southern Nevada. The similarity of velocities in the carbonate-rock aquifers in the two different areas indicates that the adjusted ages of the ground water are reasonable. The large discrepancy in velocities calculated from age and hydrologic data for flow from the Spring Mountains to adjacent valleys shows the significant lack of knowledge about the recharge process for the carbonate-rock aquifers of southern Nevada. 


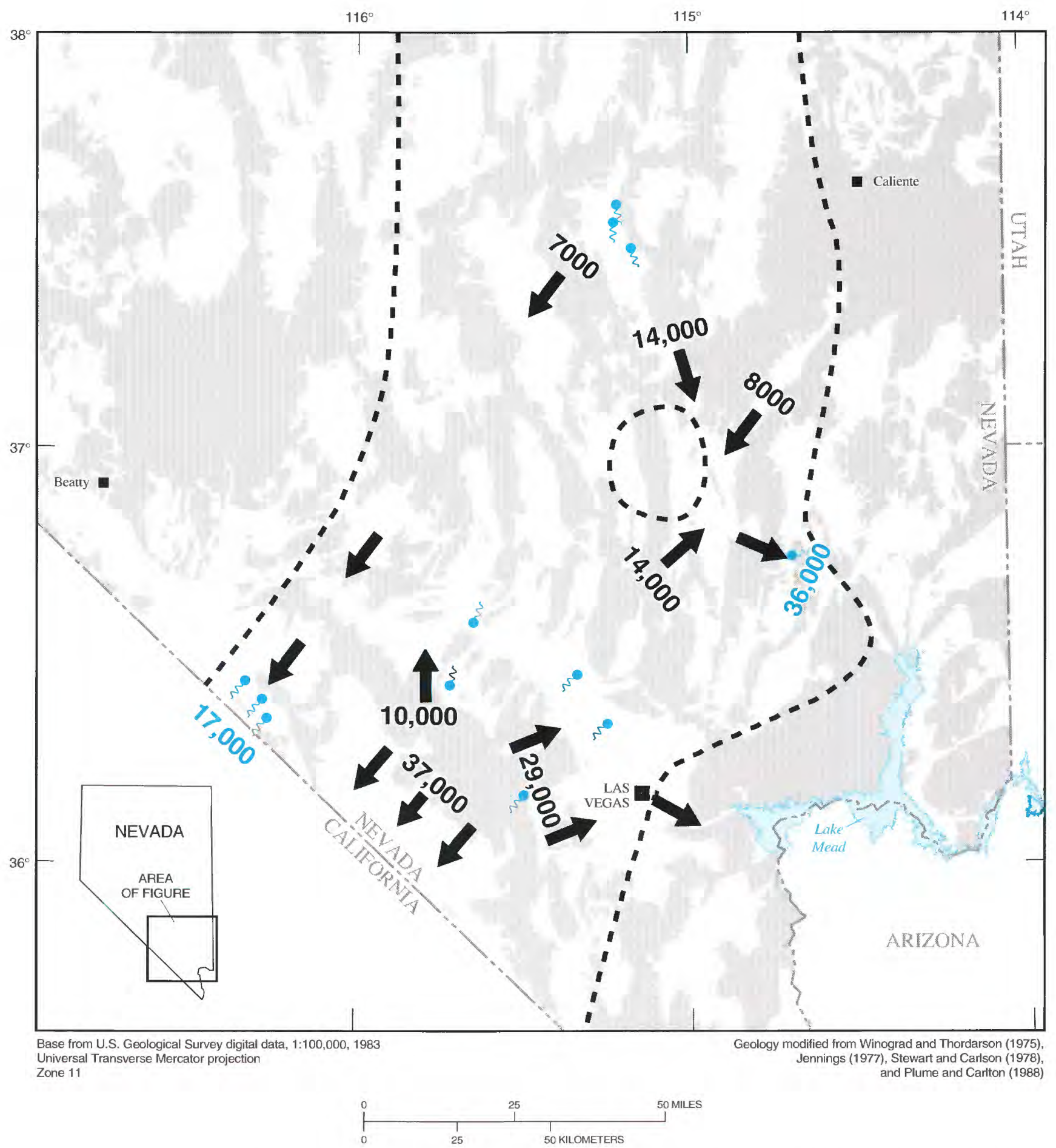

FIGURE 24.-Ground-water flow (rate and direction) in carbonate-rock aquifers of southern Nevada. Modified from Prudic and others (1995, p. D52) and Thomas and others (1996, p. 40). 
TABLE 9.- Flow velocities in carbonate-rock aquifers, southern Nevada, calculated from adjusted carbon-14 ages and hydrologic data

\begin{tabular}{|c|c|c|c|c|c|c|}
\hline \multirow{2}{*}{ Flow path } & \multirow{2}{*}{$\begin{array}{l}\text { Traveltime }^{1} \\
\text { (years) }\end{array}$} & \multirow{2}{*}{$\begin{array}{c}\text { Horizontal } \\
\text { flow-path } \\
\text { distance } \\
\text { (miles) }\end{array}$} & \multirow{2}{*}{$\begin{array}{l}\text { Changes in } \\
\text { hydraulic } \\
\text { head }^{2} \\
\text { (feet) }\end{array}$} & \multirow{2}{*}{$\begin{array}{c}\text { Hydraulic } \\
\text { gradient } \\
\text { (feet per mile) }\end{array}$} & \multicolumn{2}{|c|}{$\begin{array}{l}\text { Flow velocity } \\
\text { (feet per year) }\end{array}$} \\
\hline & & & & & $\begin{array}{c}\text { Based on } \\
\text { carbon-14 ages }\end{array}$ & $\begin{array}{c}\text { Based on } \\
\text { hydrologic data }\end{array}$ \\
\hline \multicolumn{7}{|c|}{ White River flow system } \\
\hline Coyote Spring Valley to Muddy River springs & 2,700 & 15 & 50 & 3.3 & 29 & 50 \\
\hline Sheep Range to Muddy River springs & 5,400 & 30 & 100 & 3.3 & 29 & 50 \\
\hline Pahranagat Valley to Coyote Spring Valley & 6,900 & 50 & 1,800 & 36 & 38 & 540 \\
\hline Meadow Valley Wash to Coyote Spring Valley & 5,700 & 40 & 1,400 & 35 & 37 & 520 \\
\hline \multicolumn{7}{|c|}{ Ash Meadows flow system } \\
\hline Spring Mountains to Ash Meadows springs & 2,200 & 60 & 1,400 & 23 & 140 & 350 \\
\hline Pahranagat Valley to Ash Meadows springs & 5,900 & 95 & 1,300 & 14 & 85 & 200 \\
\hline \multicolumn{7}{|c|}{ Las Vegas Valley } \\
\hline Central part of Spring Mountains to Tule Spring area & 6,600 & 15 & 500 & 33 & 12 & 500 \\
\hline $\begin{array}{l}\text { Southern part of Spring Mountains to southwest Las } \\
\text { Vegas Valley. }\end{array}$ & 5,500 & 10 & 500 & 50 & 9.6 & 740 \\
\hline \multicolumn{7}{|c|}{ Pahrump Valley } \\
\hline Spring Mountains to Pahrump Valley & 680 & 10 & 500 & 50 & 78 & 740 \\
\hline
\end{tabular}

${ }^{1}$ Adjusted carbon-14 traveltime between two samples along flow path, or for two mixing waters; for mixing waters, traveltime depends on hydraulic gradients of two separate flow paths.

${ }^{2}$ Differences in water level between source area and end of flow path. Head difference in Spring Mountains was calculated assuming that water levels are 500 feet higher than water levels in wells or springs on adjacent fans rather than by using water levels of apparently perched springs or water levels in wells completed in localized areas of alluvium in mountains.

${ }^{3}$ Flow velocity was calculated by dividing horizontal flow-path distance by adjusted carbon-14 age.

\section{EXPLANATION}

\section{Basin fill}

\section{Consolidated rock}

Generalized direction and rate of ground-water flow in carbonate-rock aquifers - Number is flow rate, in acrefeet per year. Based on deuterium mass-balance mixing models

Spring discharging from carbonate-rock aquifer-Number is discharge, in acre-feet per year

$=-$ - $=$ Boundary of central corridor of thick carbonate rocksApproximately located

\section{REFERENCES CITED}

[Note: Bold type indicates publication produced as part of Great Basin Regional AquiferSystem Analysis.]

Allmendinger. R.W., Hauge. T.A., Hauser. E.C., Potter. C.J.. Klemperer. S.H., Nelson, K.D., Kneupfer, P., and Oliver, J., 1987, Overview of the COCORP $40^{\circ} \mathrm{N}$. transect, Western United States-The fabric of an orogenic belt: Geological Society of America Bulletin. v. 98, p. 308-319.

Allmendinger, R.W., Sharp, J.W., Von Tish, D., Serpa, L., Brown, L., Kaufman, S., Oliver, J., and Smith, R.B., 1983, Cenozoic and Mesozoic structure of the eastern Basin and Range Province, Utah, from COCORP seismic-reflection data: Geology, v. 11, p. 532-536.

Anderson, R.E., Zoback, M.L., and Thompson, G.A., 1983, Implications of selected subsurface data on the structural form and evolution of some basins in the northern Basin and Range Province, Nevada and Utah: Geological Society of America Bulletin, v. 94. p. 1055-1072.

Anderson, T.W., 1985, Geohydrology of the southwest alluvial basins, Arizona, in Anderson, T.W., and Johnson, A.I.. eds., Regional aquifer systems of the United States-Southwest alluvial basins of Arizona: American Water Resources Association Monograph Series, no. 7, p. 99-111.

Anderson, T.W., Freethey, G.W., and Tucci, Patrick, 1992, Geohydrology and water resources of alluvial basins in south-central Arizona and parts of adjacent States: U.S. Geological Survey Professional Paper 1406-B, 67 p., 3 pls.

Baker, C.H., 1974, Water resources of the Curlew Valley drainage basin, Utah and Idaho: Utah Department of Natural Resources Technical Publication 45, $91 \mathrm{p}$.

Bedinger, M.S., Gates, J.S., and Stark, J.R., 1984, Maps showing ground-water units and withdrawal, Basin and Range Province, Utah: U.S. Geological Survey Water-Resources Investigations Report 83-4122-A, 13 p., 1 pl. 
Bedinger, M.S., Harrill, J.R., and Thomas, J.M., 1984, Maps showing groundwater units and withdrawal, Basin and Range Province, Nevada: U.S. Geological Survey Water-Resources Investigations Report 83-4119-A, 10 p., 2 pls.

Berger, D.L., 1992, Lithologic properties of carbonate-rock aquifers at five test wells in the Coyote Spring Valley area, southern Nevada, as determined from geophysical logs: U.S. Geological Survey Water-Resources Investigations Report 91-4167, 27 p.

Blankennagel, R.K., and Weir, J.E., Jr., 1973, Geohydrology of the eastern part of Pahute Mesa, Nevada Test Site, Nye County, Nevada: U.S. Geological Survey Professional Paper 7I2-B, 35 p.

Bolke, E.L., and Price, Don, 1969, Hydrologic reconnaissance of Curlew Valley, Utah and Idaho: Utah Department of Natural Resources Technical Publication $25,40 \mathrm{p}$.

---1972, Hydrologic reconnaissance of the Blue Creek Valley area, Box Elder County, Utah: Utah Department of Natural Resources Technical Publication $37,38 \mathrm{p}$.

Bolke, E.L., and Sumsion, C.T., 1978, Hydrologic reconnaissance of the Fish Springs Flat area, Tooele, Juab, and Millard Counties, Utah: Utah Department of Natural Resources Technical Publication 64, 30 p.

Bredehoeft, J.D., Back, W., and Hanshaw, B.B., 1982, Regional ground-water flow concepts in the United States-Historical perspective, in Narasimhan, T.N., ed., Recent trends in hydrogeology: Geological Society of America Special Paper 189, p. 297-316.

Bunch, R.L., and Harrill, J.R., 1984, Selected hydrologic data from the MX missile-siting investigation, east-central Nevada and western Utah: U.S. Geological Survey Open-File Report 84-702, 123 p.

Burbey, T.J., and Prudic, D.E., 1985, Simulation of regional ground-water flow in carbonate-rock aquifers of the Great Basin in Nevada, Utah, and adjacent States [abs.]: Geological Society of America Abstracts with Programs, v. 17, p. 534.

Campana, M.E., and Boone, R.L., 1986, Hydrologic monitoring of subsurface flow and groundwater recharge in a mountain watershed, in Cold Regions Hydrology Symposium, 1986, Proceedings: American Water Resources Association, p. 263-273.

Cardinalli, J.L., Roach, L.M., Rush, F.E., and Vasey, B.J., 1968, State of Nevada hydrographic areas: Nevada Division of Water Resources map, scale $1: 500,000$.

Carey, A.E., 1994, Documentation of model input and output values used for analyses of simulated development in Stagecoach Valley, Lyon and Storey Counties, western Nevada: U.S. Geological Survey Open-File Report 92-630, 4 p., 1 diskette.

Carey, A.E., and Prudic, D.E., 1996, Documentation of model input and output values for simulation of pumping effects in Paradise Valley, a basin tributary to the Humboldt River, Humboldt County, Nevada: U.S. Geological Survey Open-File Report 92-491, 4 p., 1 diskette.

Carlton, S.M., 1985, Fish Springs multibasin flow system, Nevada and Utah: Reno, University of Nevada, Mackay School of Mines M.S. thesis no. 1941, 103 p.

Carlton, S.M., and Thomas, J.M., 1987, Documentation for a digital computer model of the basin-fill aquifer in Smith Creek Valley, Lander County, Nevada: National Technical Information Service Reports PB87-142-899/PB-87-142-907, 6 p., 1 magnetic tape.

Carman, R.L., 1985, Estimating evapotranspiration from a phreatophyte area in Smith Creek Valley, Nevada [abs.], in Conference on Agricultural and Forest Meteorology, 17th, and on Biometeorology and Aerobiology, 7th, Scottsdale, Ariz., May 1985 [Proceedings]: Boston, American Meteorological Society, p. 48.

----1989, Data on evapotranspiration in phreatophyte areas, Smith Creek Valley and Carson Desert, west-central Nevada, 1983: National Technical Information Service Reports PB-89-167-407/PB-89-167-399, 14 p., magnetic tape.
----1993, Measurement of evapotranspiration in phreatophyte areas, Smith Creek Valley and Carson Desert, west-central Nevada, 1983: U.S. Geological Survey Water-Resources Investigations Report 89$4118,18 \mathrm{p}$.

Carpenter, Everett, 1915, Ground water in southeastern Nevada: U.S. Geological Survey Water-Supply Paper 365, 86 p.

Cohen, Philip, 1964, A brief appraisal of the ground-water resources of the Grass Valley area, Humboldt and Pershing Counties, Nevada: Nevada Department of Conservation and Natural Resources Ground-Water Resources Reconnaissance Report 29,40 p.

Cohen, Philip, and Everett, D.E., 1963, A brief appraisal of the ground-water hydrology of the Dixic-Fairview Valley area: Nevada Department of Conservation and Natural Resources Ground-Water Resources Reconnaissance Report 23, $40 \mathrm{p}$.

Cook, K.L, Montgomery, J.R., Smith, J.T., and Gray, E.F., 1975, Simple Bouguer gravity anomaly map of Utah: Utah Geological and Mineral Survey Map 37, scale 1:1,000,000.

Crosthwaite, E.G., 1963, Ground-water appraisal of Antelope and middle Reese River Valleys. Lander County, Nevada: Nevada Department of Conservation and Natural Resources Reconnaissance Report 19, 33 p.

Dettinger, M.D., 1989a, Distribution of carbonate-rock aquifers in southern Nevada and the potential for their development-Summary of findings, 1985-88: U.S. Geological Survey and Desert Research Institute of the University of Nevada, Program for the Study and Testing of Carbonate-Rock Aquifers in Eastern and Southern Nevada Summary Report no. 1, 37 p.

----1989b, Reconnaissance estimates of natural recharge to basins in Nevada, U.S.A, by using chloride-balance calculations: Journal of Hydrology, v. 106, p. 55-78.

Dettinger, M.D., Harrill, J.R., Schmidt, D.L., and Hess, J.W., 1995, Distribution of carbonate-rock aquifers and the potential for their development, southern Nevada and parts of Arizona, California, and Utah: U.S. Geological Survey Water-Resources Investigations Report 91-4146. 100 p.

Dinwiddie, G.A., and Schroder, L.J., 1971, Summary of hydraulic testing in and chemical analyses of water samples from deep exploratory holes in Little Fish Lake, Monitor. Hot Creek. and Little Smoky Valleys. Nevada: U.S. Geological Survey Report USGS-474-90, 70 p.

Downey, J.S., 1984, Geohydrology of the Madison and associated aquifers in parts of Montana, North Dakota, South Dakota, and Wyoming: U.S. Geological Survey Professional Paper 1273-G, 47 p.

Eakin, T.E., 1960, Ground-water appraisal of Newark Valley, White Pine County, Nevada: Nevada Department of Conservation and Natural Resources Ground-Water Resources Reconnaissance Report 1, 33 p.

----1961a, Ground-water appraisal of Long Valley, White Pine and Elko Counties. Nevada: Nevada Department of Conservation and Natural Resources Ground-Water Resources Reconnaissance Report 3, 35 p.

-..--1961b, Ground-water appraisal of Pine Valley, Eureka and Elko Counties, Nevada: Nevada Department of Conservation and Natural Resources Ground-Water Resources Reconnaissance Report 2, 41 p.

----1962a, Ground-water appraisal of Cave Valley in Lincoln and White Pine Counties, Nevada: Nevada Department of Conservation and Natural Resources Reconnaissance Report 13, 19 p.

---1962b, Ground-water appraisal of Gabbs Valley, Mineral and Nye Counties, Nevada: Nevada Department of Conservation and Natural Resources Reconnaissance Report 9.27 p.

----1962c, Ground-water appraisal of the Imlay area, Humboldt River Basin, Pershing County, Nevada: Nevada Department of Conservation and Natural Resources Reconnaissance Report 5, 54 p.

---1963a, Ground-water appraisal of Dry Lake and Delamar Valleys, Lincoln and Nye Counties, Nevada: Nevada Department of Conservation and Natural Resources Reconnaissance Report 16, 26 p.

-.--1963b, Ground-water appraisal of Garden and Coal Valleys, Lincoln and Nye Counties, Nevada: Nevada Department of Conservation and Natural Resources Reconnaissance Report 18, 29 p. 
-----1963c, Ground-water appraisal of Pahranagat and Pahroc Valleys, Lincoln and Nye Counties, Nevada: Nevada Department of Conservation and Natural Resources Ground-Water Resources Reconnaissance Report 21, 36 p.

-----1964, Ground-water appraisal of Coyote Spring and Kane Springs Valleys and Muddy River springs area, Lincoln and Clark Counties, Nevada: Nevada Department of Conservation and Natural Resources Ground-Water Resources Reconnaissance Report 25, $40 \mathrm{p}$.

-----1966, A regional interbasin groundwater system in the White River area, southeastern Nevada: Water Resources Research, v. 2, no. 2, p. 251-271.

Eakin, T.E., Hughes, J.L., and Moore, D.O., 1967, Water-resources appraisal of Steptoe Valley, White Pine and Elko Counties, Nevada: Nevada Department of Conservation and Natural Resources Water Resources Reconnaissance Report 42, $48 \mathrm{p}$.

Eakin, T.E., Maxey, G.B., Robinson, T.W., Fredricks, J.C., and Loeltz, O.J., 1951, Contributions to the hydrology of eastern Nevada: Nevada State Engineer Water Resources Bulletin 12, 171 p.

Eakin, T.E., Moore, D.O., and Everett, D.E., 1964, Water-resources appraisal of the upper Reese River Valley, Lander and Nye Counties, Nevada: Nevada Department of Conservation and Natural Resources Water Resources Reconnaissance Report 31, $47 \mathrm{p}$

Eakin, T.E., Price, Don, and Harrill, J.R., 1976, Summary appraisals of the Nation's ground-water resources-Great Basin region: U.S. Geological Survey Professional Paper 813-G, 37 p., 1 pl.

Emme, D.H., 1986, Delineation of subsurface flow in the upper Meadow Valley Wash area, southeastern Nevada: Reno, University of Nevada, M.S. thesis, $90 \mathrm{p}$.

Everett, D.E., 1964, Ground-water appraisal of Edwards Creek Valley, Churchill County, Nevada: Nevada Department of Conservation and Natural Resources Ground-Water Resources Reconnaissance Report 26, 18 p.

Everett, D.E., and Rush, F.E., 1964, Ground-water appraisal of Smith Creek and Ione Valleys, Lander and Nye Counties, Nevada: Nevada Department of Conservation and Natural Resources Ground-Water Resources Reconnaissance Report 28, 21 p.

-----1965, Water-resources appraisal of Lovelock Valley, Pershing County, Nevada: Nevada Department of Conservation and Natural Resources Water Resources Reconnaissance Report 32, 40 p.

-----1966, A brief appraisal of the water resources of Grass and Carico Lake Valleys, Lander and Eureka Counties, Nevada: Nevada Department of Conservation and Natural Resources Water Resources Reconnaissance Report $37,28 \mathrm{p}$.

-----1967, A brief appraisal of the water resources of the Walker Lake area, Mineral, Lyon, and Churchill Counties, Nevada: Nevada Department of Conservation and Natural Resources Water Resources Reconnaissance Report 40, $44 \mathrm{p}$.

Fenneman, N.M., and Johnson, D.W., 1946, Physical division of the United States: U.S. Geological Survey map, scale 1:7,000,000.

Fiero, G.W., Jr., 1968, Regional ground-water flow systems of central Nevada: Reno, University of Nevada Desert Research Institute Miscellaneous Report 5, $213 \mathrm{p}$.

Freeze, A.R, and Witherspoon, P.A., 1966, Theoretical analysis of regional groundwater flow, Pt. 1, Analytical and numerical solutions to the mathematical model: Water Resources Research, v. 2, no. 4, p. 641-656.

----1967, Theoretical analysis of regional groundwater flow, Pt. 2, Effect of water-table configurations and subsurface permeability variation: Water Resources Research, v. 3, no. 2, p. 623-634.

Galloway, Devin, 1986, Estimates of confined and unconfined aquifer characteristics from ground-water level fluctuations induced by Earth tides and barometric fluctuations, Yucca Mountain, Nevada [abs.]: Eos (American Geophysical Union Transactions), v. 67, no. 44, p. 942.

Gates, J.S., 1984, Hydrogeology of northwestern Utah and adjacent parts of Idaho and Nevada: Utah Geological Association Publication 13, p. 239-248.
Gates, J.S., and Kruer, S.A., 1981, Hydrologic reconnaissance of the southern Great Salt Lake Desert and summary of the hydrology of west-central Utah: Utah Department of Natural Resources Technical Publication 71, $55 \mathrm{p}$.

Glancy, P.A., 1968a, Water-resources appraisal of Butte Valley, Elko and White Pine Counties, Nevada: Nevada Division of Water Resources Reconnaissance Report 49, $50 \mathrm{p}$.

----1968b, Water-resources appraisal of Mesquite-Ivanpah Valley area, Nevada and California: Nevada Division of Water Resources Reconnaissance Report 46, $57 \mathrm{p}$.

----1971, Water-resources appraisal of Antelope Valley and East Walker area Nevada and California: Nevada Division of Water Resources Reconnaissance Report 53, 69 p.

-----1986, Geohydrology of the basalt and unconsolidated sedimentary aquifers in the Fallon area, Churchill County, Nevada: U.S. Geological Survey Water-Supply Paper 2263, 62 p.

Glancy, P.A., and Katzer, T.L., 1976, Water-resources appraisal of the Carson River Basin, western Nevada: Nevada Division of Water Resources Reconnaissance Report 59, $126 \mathrm{p}$

Glancy, P.A., and Rush, F.E., 1968, Water-resources appraisal of Smoke CreekSan Emidio Desert area, Nevada and California: Nevada Department of Conservation and Natural Resources Water Resources Reconnaissance Report 44, $57 \mathrm{p}$.

Glancy, P.A., and Van Denburgh, A.S., 1969, Water-resources appraisal of the lower Virgin River valley area, Nevada, Arizona, and Utah: Nevada Division of Water Resources Reconnaissance Report 44, 57 p.

Harrill, J.R., 1968, Hydrologic response to irrigation pumping in Diamond Valley, Eureka and Elko Counties, Nevada, 1959-65, with a section on Surface water, by R.D. Lamke: Nevada Department of Conservation and Natural Resources Water Resources Bulletin 35, 85 p.

---1969, Hydrologic response to irrigation pumping in Hualapai Flat, Washoe, Pershing, and Humboldt Counties, Nevada, 1960-67: Nevada Department of Conservation and Natural Resources Water Resources Bulletin 37, $75 \mathrm{p}$.

-.-.-1970, Water-resources appraisal of the Granite Springs Valley area, Pershing, Churchill, and Lyon Counties, Nevada: Nevada Division of Water Resources Reconnaissance Report 56, $46 \mathrm{p}$.

---1971, Water-resources appraisal of the Pilot Creek Valley area, Elko and White Pine Counties, Nevada: Nevada Division of Water Resources Reconnaissance Report 56, 46 p.

----1973, Evaluation of the water resources of Lemmon Valley, Washoe County, Nevada, with emphasis on effects of ground-water development to 1971: Nevada Division of Water Resources Bulletin 42, 130 p.

-.---1984, Great Basin aquifer systems, Nevada-Utah-An overview, in Repogle, J.A., and Renard, K.G., eds., Specialty Conference on Water Today and Tomorrow, Flagstaff, Ariz., July 1984 [Proceedings]: American Society of Civil Engineers Irrigation and Drainage Division, p. 590-597.

Harrill, J.R., Gates, J.S., and Thomas, J.M., 1988, Major ground-water flow systems in the Great Basin region of Nevada, Utah, and adjacent States: U.S. Geological Survey Hydrologic Investigations Atlas HA694-C, 2 sheets.

Harrill, J.R., and Hines, L.B., 1995, Estimated natural ground-water recharge, discharge, and budget for the Dixie Valley area, west-central Nevada: U.S. Geological Survey Water-Resources Investigations Report 95-4052, 12 p.

Harrill, J.R., and Moore, D.O., 1970, Effects of ground-water development on the water regimen of Paradise Valley, Humboldt County, Nevada, 1948-68, and hydrologic reconnaissance of the tributary areas: Nevada Division of Water Resources Bulletin 39, 123 p.

Harrill, J.R., and Preissler, A.M., 1994, Ground-water flow and simulated effects of development in Stagecoach Valley, a small, partly drained basin in Lyon and Storey Counties, western Nevada: U.S. Geological Survey Professional Paper 1409-H, 74 p. 
Harrill, J.R., Welch, A.H., and Preissler, A.M., 1984, Hydrogeologic controls on ground-water flow in Stagecoach Valley, Nevada, in vol. 3 of Lintz, Joseph, Jr., ed., Western geological excursions [in conjunction with 1984 annual meetings of Geological Society of America and affiliated societies]: Reno, University of Nevada, Mackay School of Mines, p. 117-120.

----1992, Evidence for subsurface inflow to Stagecoach Valley, Lyon County, Nevada, in Subitzky, Seymour, ed., Selected papers in the hydrological sciences: U.S. Geological Survey Water-Supply Paper 2340, p. 179-192.

Harrill, J.R., Welch, A.H., Prudic, D.E., Thomas, J.M., Carman, R.L., Plume, R.W., Gates, J.S., and Mason, J.L., 1983, Aquifer systems in the Great Basin region of Nevada, Utah, and adjacent States-A study plan: U.S. Geological Survey Open-File Report 82-445, 49 p.

Hildenbrand, T.G., Kucks, R.P., and Sweeney, R.E., 1983, Digital colored magnetic-anomaly map of the Basin and Range Province: U.S. Geological Survey Open-File Report 83-189, 11 p.

Hines, L.B., 1992, Quantification of natural ground-water evapotranspiration in Smith Creek Valley, Lander County, Nevada, in Subitzky, Seymour, ed., Selected papers in the hydrological sciences: U.S. Geological Survey Water-Supply Paper 2340, p. 9-20.

Hintze, L.F., 1963, Geologic map of southwestern Utah: Provo, Utah, Brigham Young University Department of Geology, scale 1:250,000.

----1980, Geologic map of Utah: Utah Geological and Mineral Survey, scale 1:500,000.

Hood, J.W., 1971a, Hydrologic reconnaissance of Hansel Valley and northern Rozel Flat, Box Elder County, Utah: Utah Department of Natural Resources Technical Publication 33, 41 p.

----1971b, Hydrologic reconnaissance of the Park Valley area, Box Elder County, Utah: Utah Department of Natural Resources Technical Publication $30,51 \mathrm{p}$.

Hood, J.W., and Price, Don, 1970, Hydrologic reconnaissance of Grouse Creek Valley, Box Elder County, Utah: Utah Department of Natural Resources Technical Publication 29, $53 \mathrm{p}$.

Hood, J.W., Price, Don, and Waddell, K.M., 1969, Hydrologic reconnaissance of Rush Valley, Tooele County, Utah: Utah Department of Natural Resources Technical Publication 23, 63 p.

Hood, J.W., and Rush, F.E, 1965, Water-resources appraisal of the Snake Valley area, Utah and Nevada: Utah State Engineer Technical Publication 14, 43 p.

Hood, J.W., and Waddell, K.M., 1969, Hydrologic reconnaissance of Deep Creek Valley, Tooele and Juab Counties, Utah, and Elko and White Pine Counties, Nevada: Utah Department of Natural Resources Technical Publication $24,54 \mathrm{p}$.

Huxel, C.J., Jr., and Harris, E.E., 1969, Water resources and development in Mason Valley, Lyon and Mineral Counties, Nevada, 1948-65: Nevada Division of Water Resources Bulletin 38, $77 \mathrm{p}$.

Huxel, C.J., Jr., Parkes, J.E., and Everett, D.E., 1966, Effects of irrigation development on the water supply of Quinn River Valley area, Nevada and Oregon, 1950-64: Nevada Department of Conservation and Natural Resources Water Resources Bulletin 34, 80 p.

Jennings, C.W., comp., 1977, Geologic map of California: California Division of Mines and Geology Geologic Data Map 2, scale 1:750,000.

Kohler, M.A., Nordenson, T.J., and Baker, D.R., 1959, Evaporation maps for the United States: U.S. Department of Commerce Weather Bureau Technical Paper 37, 13 p.

Langenheim, R.L., Jr., and Larson, E.R., 1973, Correlation of Great Basin stratigraphic units: Nevada Bureau of Mines and Geology Bulletin 72, $19 \mathrm{p}$.

Malmberg, G.T., and Eakin, T.E., 1962, Ground-water appraisal of Sarcobatus Flat and Oasis Valley, Nye and Esmeralda Counties, Nevada: Nevada Department of Conservation and Natural Resources Ground-Water Resources Reconnaissance Report 10,39 p.
Malmberg, G.T., and Worts, G.F., 1966, The effects of pumping on the hydrology of Kings River Valley, Humboldt County, Nevada, 1957-64: Nevada Department of Conservation and Natural Resources Water Resources Bulletin $31,57 \mathrm{p}$.

Mason, J.L., 1998, Ground-water hydrology and simulated effects of development in the Milford area, an arid basin in southwestern Utah: U.S. Geological Survey Professional Paper 1409-G, 78 p., 2 pls.

Mason, J.L., Atwood, John, and Buettner, Priscilla, 1985, Selected test well data from the MX missile system study, Tooele, Millard, Beaver, and Iron Counties, Utah: U.S. Geological Survey Open-File Report 85-347, 13 p., 1 pl.

Maxey, G.B., and Eakin, T.E., 1949, Ground water in White River Valley, White Pine, Nye, and Lincoln Counties, Nevada: Nevada State Engineer, Water Resources Bulletin 8, 59 p.

McDonald, M.G., and Harbaugh, A.W., 1988, A modular three-dimensional finite-difference ground-water flow model: U.S. Geological Survey Techniques of Water-Resources Investigations, book 6, chap. A1, 586 p.

Meinzer, O.E., 1917, Geology and water resources of Big Smoky, Clayton, and Alkali Spring Valleys, Nevada: U.S. Geological Survey Water-Supply Paper $423,167 \mathrm{p}$.

Mendenhall, W.C., 1909, Some desert watering places in southeastern California and southwestern Nevada: U.S. Geological Survey Water-Supply Paper 224,98 p.

Mifflin, M.D., 1968, Delineation of ground-water flow systems in Nevada: University of Nevada Desert Research Institute Technical Report H-W no. 4, $112 \mathrm{p}$.

----1988, Region 5, Great Basin, in Back, William, Rosenshein, J.S., and Seaber, P.R., eds., Hydrogeology: Boulder, Colo., Geological Society of America, The geology of North America, v. O-2, p. 69-78.

Mifflin, M.D., and Harrill, J.R., 1981, Hydrogeologic characteristics of the Great Basin [abs.]: Geological Society of America Abstracts with Programs, v. 13, no. 7, p. 510.

Miller, G.A., 1977, Appraisal of the water resources of Death Valley, California-Nevada: U.S. Geological Survey Open-File Report 77-728, 68 p.

Mower, R.W., 1965, Ground-water resources of Pavant Valley, Utah: U.S. Geological Survey Water-Supply Paper 1974, 78 p.

Nolan, T.B., 1943, The Basin and Range Province in Utah, Nevada, and California, chap. D of Shorter contributions to general geology, 1941-42: U.S. Geological Survey Professional Paper 197-D, p. 141-196.

Peterson, D.L., 1974, Bouguer gravity map of parts of the northern Lake Bonneville Basin, Utah and Idaho: U.S. Geological Survey Miscellaneous Field Studies Map MF-627, scale 1:250,000.

Plume, R.W., 1984, Use of aeromagnetic data to define some properties of a carbonate-rock aquifer in eastern Nevada [abs.]: Geological Society of America, Abstracts with Programs, v. 16, no. 6., p. 624.

----1985, Geologic features that control regional ground-water movement in the eastern Great Basin, Nevada and Utah [abs.]: Geological Society of America Abstracts with Programs, v. 17, p. 691.

----1988a, Geologic features that affect the movement of recharge to ground-water basins adjacent to the central Egan Range, White Pine County, Nevada [abs.]: Geological Society of America Abstracts with Programs, v. 20, no. 3, p. 221.

----1988b, Use of aeromagnetic data to define boundaries of a carbonaterock aquifer in east-central Nevada, in Subitzky, Seymour, ed., Selected papers in the hydrological sciences: U.S. Geological Survey Water-Supply Paper 2330, p. 1-10.

-.---1996, Hydrogeologic framework of aquifer systems in the Great Basin region of Nevada, Utah, and adjacent States: U.S. Geological Professional Paper 1409-B, 64 p.

Plume, R.W., and Carlton, S.M., 1988, Hydrogeology of the Great Basin region of Nevada, Utah, and adjacent States: U.S. Geological Survey Hydrologic Investigations Atlas HA-694-A, scale 1:1,000,000. 
Price, Don, and Bolke, E.L., 1976, Hydrologic reconnaissance of the Sink Valley area, Tooele and Box Elder Counties, Utah: Utah Department of Natural Resources Technical Publication 26, 34 p.

Prudic, D.E., Harrill, J.R., and Burbey, T.J., 1995, Conceptual evaluation of regional ground-water flow in the carbonate-rock province of the Great Basin, Nevada, Utah, and adjacent States: U.S. Geological Survey Professional Paper 1409-D, 102 p.

Prudic, D.E., and Herman, M.E., 1996, Ground-water flow and simulated effects of development in Paradise Valley, a basin tributary to the Humboldt River in Humboldt County, Nevada: U.S. Geological Survey Professional Paper 1409-F, 92 p.

Prudic, D.E., and Wood, J.L., 1995, Results of hypothetical ground-water pumping in Carson Valley, a river-dominated basin in Douglas County, Nevada, and Alpine County, California: U.S. Geological Survey WaterResources Investigations Report 95-4174, 29 p.

Robbins, S.L., Prudic, D.E., Schaefer, D.H., and Clutsom, F.G., 1985, Principal facts and density estimates for borehole gravity stations in three water wells located in Dixie and Paradise Valleys, Nevada: U.S. Geological Survey Open-File Report 85-426, 20 p.

Robinson, T.W., 1970, Evapotranspiration by woody phreatophytes in the Humboldt River valley near Winnemucca, Nevada, with a section on Soil-moisture determinations, by A.O. Waananen: U.S. Geological Survey Professional Paper 491-D, 41 p.

Rush, F.E., 1964, Ground-water appraisal of the Meadow Valley area, Lincoln and Clark Counties, Nevada: Nevada Department of Conservation and Natural Resources Ground-Water Resources Reconnaissance Report 27, 43 p.

----1967, Water-resources appraisal of Washoe Valley, Nevada: Nevada Department of Conservation and Natural Resources Water Resources Reconnaissance Report 41, 39 p.

-----1968a, Index of hydrographic areas in Nevada: Nevada Division of Water Resources Information Report 6,38 p.

-----1968b, Water-resources appraisal of Clayton Valley-Stonewall Flat area, Nevada and California: Nevada Department of Conservation and Natural Resources Water Resources Reconnaissance Report 45, 54 p.

----1968c, Water-resources appraisal of the Lower Moapa-Lake Mead area, Clark County, Nevada: Nevada Division of Water Resources Reconnaissance Report 50, $66 \mathrm{p}$.

----1968d, Water-resources appraisal of Thousand Springs Valley, Elko County, Nevada: Nevada Division of Water Resources Reconnaissance Report 47,61 p.

-----1971, Regional ground-water systems in the Nevada Test Site area, Nye, Lincoln, and Clark Counties, Nevada: Nevada Division of Water Resources Reconnaissance Report 54, 25 p.

Rush, F.E., and Eakin, T.E., 1963, Ground-water appraisal of Lake Valley in Lincoln and White Pine Counties, Nevada: Nevada Department of Conservation and Natural Resources Ground-Water Resources Reconnaissance Report 24, 29 p.

Rush, F.E., and Everett, D.E., 1966, Water-resources appraisal of Little Fish Lake, Hot Creek, and Little Smoky Valleys, Nevada: Nevada Department of Conservation and Natural Resources Reconnaissance Report 38, 39 p.

Rush, F.E., and Glancy, P.A., 1967, Water-resources appraisal of the Warm Springs-Lemmon Valley area, Washoe County, Nevada: Nevada Department of Conservation and Natural Resources Water Resources Reconnaissance Report 43, $70 \mathrm{p}$.

Rush, F.E., and Huxel, C.J., 1966, Ground-water appraisal of the EldoradoPiute Valley area, Nevada and California: Nevada Department of Conservation and Natural Resources Water Resources Reconnaissance Report 36, 30 p.

Rush, F.E., and Katzer, T.L., 1973, Water-resources appraisal of Fish Lake Valley, Nevada and California: Nevada Division of Water Resources Reconnaissance Report $58,70 \mathrm{p}$
Rush, F.E., and Kazmi, S.A.T., 1965, Water-resources appraisal of Spring Valley, White Pine and Lincoln Counties, Nevada: Nevada Department of Conservation and Natural Resources Water Resources Reconnaissance Report 33, $39 \mathrm{p}$.

Rush, F.E., and Schroer, C.V., 1971, Water resources of Big Smoky Valley, Lander, Nye, and Esmeralda Counties, Nevada: Nevada Division of Water Resources Bulletin 41, 84 p.

-----1976, Geohydrology of Smith Valley, Nevada, with special reference to the water-use period 1953-72: Nevada Division of Water Resources Bulletin $43,95 \mathrm{p}$.

Schaefer, D.H., 1988, Bouguer gravity anomaly maps of Paradise, Stagecoach, Dixie, Fairview, and Stingaree Valleys, northwestern Nevada: U.S. Geological Survey Geophysical Investigations Map GP-985.

Schaefer, D.H., 1993, Documentation of model input and output values for simulation of regional ground-water flow, carbonate-rock province, Nevada, Utah, and adjacent States: U.S. Geological Survey Open-File Report 93-420 (revision of Open-File Report 91-479), 4 p., 1 diskette.

Schaefer, D.H., Duffrin, B.G., and Plume, R.W., 1986, Principal facts for gravity stations in Paradise and Stagecoach Valleys, Humboldt and Lyon Counties, Nevada: U.S. Geological Survey Open-File Report 85694, 15 p.

Schaefer, D.H., Thomas, J.M., and Duffrin, B.G., 1984, Principal facts for gravity stations in Dixie, Fairview, and Stingaree Valleys, Churchill and Pershing Counties, Nevada: U.S. Geological Survey Open-File Report 84-586, 15 p.

Schulke, D.F., ed., 1987, Great Basin recharge studies: University of Nevada Desert Research Institute Water-Resources Center Publication 41104, 127 p.

Scott, B.R., Smales, T.J., Rush, F.E., and Van Denburgh. A.S., 1971, Nevada's water resources: Nevada Division of Water Resources Water for Nevada Report 3, 87 p.

Sinclair, W.C., 1962a, Ground-water resources of Desert Valley, Humboldt and Pershing Counties, Nevada: Nevada Department of Conservation and Natural Resources Ground-Water Resources Reconnaissance Report 7, 23 p.

----1962b, Ground-water resources of Pine Forest Valley, Humboldt County, Nevada: Nevada Department of Conservation and Natural Resources Ground-Water Resources Reconnaissance Report 4, 22 p.

----1963a, Ground-water appraisal of the Black Rock Desert area, northwestern Nevada: Nevada Department of Conservation and Natural Resources Ground-Water Resources Reconnaissance Report 20, 33 p.

----1963b, Ground-water appraisal of Duck Lake Valley, Washoe County, Nevada: Nevada Department of Conservation and Natural Resources Ground-Water Resources Reconnaissance Report 17, 19 p.

----1963c, Ground-water appraisal of the Long Valley-Massacre Lake region, Washoe County, Nevada: Nevada Department of Conservation and Natural Resources Ground-Water Resources Reconnaissance Report 15, 19 p.

-----1963d, Ground-water appraisal of Pueblo Valley-Continental Lake region, Humboldt County, Nevada: Nevada Department of Conservation and Natural Resources Ground-Water Resources Reconnaissance Report 22, 25 p.

Stephens, J.C., 1974a, Hydrologic reconnaissance of the northern Great Salt Lake Desert and summary hydrologic reconnaissance of northwestern Utah: Utah Department of Natural Resources Technical Publication 42, 55 p.

----1974b, Hydrologic reconnaissance of the Wah Wah Valley drainage basin, Millard and Beaver Counties, Utah: Utah Department of Natural Resources Technical Publication 47, 53 p.

----1976, Hydrologic reconnaissance of the Pine Valley drainage basin, Millard, Beaver, and Iron Counties, Utah: Utah Department of Natural Resources Technical Publication 51, $38 \mathrm{p}$.

----1977, Hydrologic reconnaissance of the Tule Valley drainage basin, Juab and Millard Counties, Utah: Utah Department of Natural Resources Technical Publication 56, $37 \mathrm{p}$.

Stephens, J.C., and Hood, J.W., 1973, Hydrologic reconnaissance of Pilot Valley, Utah and Nevada: Utah Department of Natural Resources Technical Publication 41, $38 \mathrm{p}$. 
Stephens, J.C., and Sumsion, C.T., 1978, Hydrologic reconnaissance of the Dugway Valley-Government Creek area, west-central Utah: Utah Department of Natural Resources Technical Publication 59, 42 p.

Stewart, J.H., 1980, Geology of Nevada-A discussion to accompany the geologic map of Nevada: Nevada Bureau of Mines and Geology Special Publication 4, $136 \mathrm{p}$.

-----1988, Tectonics of the Walker Lane Belt, western Great Basin-Mesozoic and Cenozoic deformation in a zone of shear, in Ernst, W.G., ed., Metamorphism and crustal evolution of the Western United States (Rubey Volume VII): Englewood Cliffs, N.J., Prentice-Hall, p. 683-713.

Stewart, J.H., and Carlson, J.E., 1978, Geologic map of Nevada: U.S. Geological Survey, scale 1:500,000.

Stokes, Lee, 1963, Geologic map of northwest Utah: Salt Lake City, University of Utah College of Mines and Mineral Industries, scale 1:250,000.

Sumsion, C.T., and others, 1976, Ground-water conditions in Utah, spring of 1976: Utah Division of Water Resources Cooperative Investigations Report $15,69 \mathrm{p}$.

Thomas, J.M., Carlton, S.M., and Hines, L.B., 1989, Ground-water flow and simulated response to selected developmental alternatives in Smith Creek Valley, a hydrologically closed basin in Lander County, Nevada: U.S. Geological Survey Professional Paper 1409-E, 57 p.

Thomas, J.M., Mason, J.L., and Crabtree, J.D., 1986, Ground-water levels in the Great Basin region of Nevada, Utah, and adjacent States: U.S. Geological Survey Hydrologic Investigations Atlas HA-694-B, 2 sheets.

Thomas, J.M., Welch, A.H., and Dettinger, M.D., 1996, 1996, Aqueous geochemistry of aquifer systems in the Great Basin region of Nevada, Utah, and adjacent States: U.S. Geological Survey Professional Paper 1409-C, $100 \mathrm{p}$.

Thomas, J.M., Welch, A.H., and Preissler, A.M., 1985, Geochemical evolution of ground water in a hydrologically closed basin, northern Basin and Range Province, Nevada [abs.], in Conference on Practical Applications of Ground-Water Geochemistry, Banff, Alberta, Canada, June 1984, Proceedings: Alberta Research Council and National Water Well Association, p. 189.

-----1989, Geochemical evolution of ground water in Smith Creek Valley, a hydrologically closed basin in central Nevada, U.S.A.: Applied Geochemistry, v. 4, p. 493-510.

Tóth, J., 1962, A theory of groundwater motion in small drainage basins in central Alberta, Canada: Journal of Geophysical Research, v. 67, no. 11, p. 4375-4387.

----1963, A theoretical analysis of ground-water flow in small drainage basins: Journal of Geophysical Research, v. 68, no. 16, p. 4795-4812.

Van Denburgh, A.S., and Glancy, P.A., 1970, Water-resources appraisal of the Columbus Salt Marsh-Soda Spring Valley area, Mineral and Esmeralda Counties, Nevada: Nevada Division of Water Resources Reconnaissance Report 52, $66 \mathrm{p}$.

Van Denburgh, A.S., Lamke, R.D., and Hughes, J.L., 1973, A brief waterresources appraisal of the Truckee River Basin, western Nevada: Nevada Division of Water Resources Reconnaissance Report 57, 122 p.

Van Denburgh, A.S., and Rush, F.E., 1974, Water-resources appraisal of Railroad and Penoyer Valleys, east-central Nevada: Nevada Division of Water Resources Reconnaissance Report 60,61 p.

Walker, G.E., and Eakin, T.E., 1963, Geology and ground water of Amargosa Desert, Nevada-California: Nevada Department of Conservation and Natural Resources Ground-Water Resources Reconnaissance Report 14, 45 p.

Welch, A.H., and Thomas, J.M., 1984, Aqueous geochemistry and isotope hydrology of the White River system, eastern Nevada [abs.]: Geological Society of America, Abstracts with Programs, v. 16, no. 6, p. 689.

Welch, A.H., and Williams, R.P., 1986a, Data on ground-water quality for the Elko $1^{\circ} \times 2^{\circ}$ quadrangle, eastern Nevada: U.S. Geological Survey Open-File Report 85-648-B, scale 1:250,000.

-----1986b, Data on ground-water quality for the Ely $1^{\circ} \times 2^{\circ}$ quadrangle, eastern Nevada: U.S. Geological Survey Open-File Report 85-648-C, scale 1:250,000. ----1986c, Data on ground-water quality for the Lund $1^{\circ} \times 2^{\circ}$ quadrangle, eastern Nevada: U.S. Geological Survey Open-File Report 85-648-D, scale 1:250,000.

----1986d, Data on ground-water quality for the Millett $1^{\circ} \times 2^{\circ}$ quadrangle, central Nevada: U.S. Geological Survey Open-File Report 85-648A, scale 1:250,000.

-----1987a, Data on ground-water quality for the Caliente $1^{\circ} \times 2^{\circ}$ quadrangle, eastern Nevada: U.S. Geological Survey Open-File Report 85-648L, scale 1:250,000.

$---1987 b$, Data on ground-water quality for the Death Valley $1^{\circ} \times 2^{\circ}$ quadrangle, southern Nevada: U.S. Geological Survey Open-File Report 85-648-M, scale 1:250,000.

$----1987 \mathrm{c}$, Data on ground-water quality for the Goldfield $1^{\circ} \times 2^{\circ}$ quadrangle, central Nevada: U.S. Geological Survey Open-File Report 85648-K, scale 1:250,000.

-----1987d, Data on ground-water quality for the Kingman $1^{\circ} \times 2^{\circ}$ quadrangle, southern Nevada: U.S. Geological Survey Open-File Report 85648-N, scale 1:250,000.

----1987e, Data on ground-water quality for the Lovelock $1^{\circ} \times 2^{\circ}$ quadrangle, western Nevada: U.S. Geological Survey Open-File Report 85648-F, scale 1:250,000.

----1987f, Data on ground-water quality for the McDermitt $1^{\circ} \times 2^{\circ}$ quadrangle, northern Nevada: U.S. Geological Survey Open-File Report 85648-E, scale 1:250,000.

----1987g, Data on ground-water quality for the Reno $1^{\circ} \times 2^{\circ}$ quadrangle, western Nevada: U.S. Geological Survey Open-File Report 85-648-H, scale 1:250,000.

-----1987h, Data on ground-water quality for the Tonopah $1^{\circ} \times 2^{\circ}$ quadrangle, central Nevada: U.S. Geological Survey Open-File Report 85648-J, scale 1:250,000.

----1987i, Data on ground-water quality for the Walker Lake $1^{\circ} \times 2^{\circ}$ quadrangle, western Nevada: U.S. Geological Survey Open-File Report 85-648-I, scale 1:250,000.

-.---1987j, Data on ground-water quality for the Winnemucca $1^{\circ} \times 2^{\circ}$ quadrangle, central Nevada: U.S. Geological Survey Open-File Report 85-648-G, scale 1:250,000.

Wernicke, Brian, 1985, Structural discordance between Neogene detachments and frontal Sevier thrusts, central Mormon Mountains, southern Nevada: Tectonics, v. 4, p. 213-246.

Winograd, I.J., 1962, Interbasin movement of ground water at the Nevada Test Site, Nevada, art. 104 in Short papers in geology and hydrology: U.S. Geological Survey Professional Paper 450-C, p. 108-111.

Winograd, I.J., and Eakin, T.E., 1965, Interbasin movement of ground water in south-central Nevada - The evidence [abs.], in Abstracts for 1964: Geological Society of America Special Paper 82, p. 227.

Winograd, I.J., and Friedman, Irving, 1972, Deuterium as a tracer of regional ground-water flow, southern Great Basin, Nevada and California: Geological Society of America Bulletin, v. 83, no. 12, p. 3691-3708.

Winograd, I.J., and Thordarson, William, 1975, Hydrogeologic and hydrogeochemical framework, south-central Great Basin, Nevada-California, with special reference to the Nevada Test Site: U.S. Geological Survey Professional Paper 712-C, 126 p., 3 pls.

Worts, G.F., Jr., and Malmberg, G.T., 1966, Hydrologic appraisal of Eagle Valley, Ormsby County, Nevada: Nevada Department of Conservation and Natural Resources Water Resources Reconnaissance Report 39, 55 p. 


\section{Selected Series of U.S. Geological Survey Publications}

\section{Books and Other Publications}

Professional Papers report scientific data and interpretations of lasting scientific interest that cover all facets of USGS investigations and research.

Bulletins contain significant data and interpretations that are of lasting scientific interest but are generally more limited in scope or geographic coverage than Professional Papers.

Water-Supply Papers are comprehensive reports that present significant interpretive results of hydrologic investigations of wide interest to professional geologists, hydrologists, and engineers. The series covers investigations in all phases of hydrology, including hydrogeology, availability of water, quality of water, and use of water.

Circulars are reports of programmatic or scientific information of an ephemeral nature; many present important scientific information of wide popular interest. Circulars are distributed at no cost to the public.

Fact Sheets communicate a wide variety of timely information on USGS programs, projects, and research. They commonly address issues of public interest. Fact Sheets generally are two or four pages long and are distributed at no cost to the public.

Reports in the Digital Data Series (DDS) distribute large amounts of data through digital media, including compact discread-only memory (CD-ROM). They are high-quality, interpretive publications designed as self-contained packages for viewing and interpreting data and typically contain data sets, software to view the data, and explanatory text.

Water-Resources Investigations Reports are papers of an interpretive nature made available to the public outside the formal USGS publications series. Copies are produced on request (unlike formal USGS publications) and are also available for public inspection at depositories indicated in USGS catalogs.

Open-File Reports can consist of basic data, preliminary reports, and a wide range of scientific documents on USGS investigations. Open-File Reports are designed for fast release and are available for public consultation at depositories.

\section{Maps}

Geologic Quadrangle Maps (GQ's) are multicolor geologic maps on topographic bases in 7.5- or 15-minute quadrangle formats (scales mainly 1:24,000 or 1:62,500) showing bedrock, surficial, or engineering geology. Maps generally include brief texts; some maps include structure and columnar sections only.

Geophysical Investigations Maps (GP's) are on topographic or planimetric bases at various scales. They show results of geophysical investigations using gravity, magnetic, seismic, or radioactivity surveys, which provide data on subsurface structures that are of economic or geologic significance.
Miscellaneous Investigations Series Maps or Geologic Investigations Series (I's) are on planimetric or topographic bases at various scales; they present a wide variety of format and subject matter. The series also incudes 7.5-minute quadrangle photogeologic maps on planimetric bases and planetary maps.

\section{Information Periodicals}

Metal Industry Indicators (MII's) is a free monthly newsletter that analyzes and forecasts the economic health of five metal industries with composite leading and coincident indexes: primary metals, steel, copper, primary and secondary aluminum, and aluminum mill products.

Mineral Industry Surveys (MIS's) are free periodic statistical and economic reports designed to provide timely statistical data on production, distribution, stocks, and consumption of significant mineral commodities. The surveys are issued monthly, quarterly, annually, or at other regular intervals, depending on the need for current data. The MIS's are published by commodity as well as by State. A series of international MIS's is also available.

Published on an annual basis, Mineral Commodity Summaries is the earliest Government publication to furnish estimates covering nonfuel mineral industry data. Data sheets contain information on the domestic industry structure, Government programs, tariffs, and 5-year salient statistics for more than 90 individual minerals and materials.

The Minerals Yearbook discusses the performance of the worldwide minerals and materials industry during a calendar year, and it provides background information to assist in interpreting that performance. The Minerals Yearbook consists of three volumes. Volume I, Metals and Minerals, contains chapters about virtually all metallic and industrial mineral commodities important to the U.S. economy. Volume II, Area Reports: Domestic, contains a chapter on the minerals industry of each of the 50 States and Puerto Rico and the Administered Islands. Volume III, Area Reports: International, is published as four separate reports. These reports collectively contain the latest available mineral data on more than 190 foreign countries and discuss the importance of minerals to the economies of these nations and the United States.

\section{Permanent Catalogs}

"Publications of the U.S. Geological Survey, 1879-1961" and "Publications of the U.S. Geological Survey, 19621970" are available in paperback book form and as a set of microfiche.

"Publications of the U.S. Geological Survey, 1971-1981" is available in paperback book form (two volumes, publications listing and index) and as a set of microfiche.

Annual supplements for 1982, 1983, 1984, 1985, 1986, and subsequent years are available in paperback book form. 